Portland State University

PDXScholar

6-28-2021

\title{
Racializing Discourses: an Exploration of Moreno Subject Formation in Oaxaca, Mexico
}

Juan Salvador Sepulveda-Figuereo

Portland State University

Follow this and additional works at: https://pdxscholar.library.pdx.edu/open_access_etds

Part of the Latin American Studies Commons, and the Social and Cultural Anthropology Commons Let us know how access to this document benefits you.

\section{Recommended Citation}

Sepulveda-Figuereo, Juan Salvador, "Racializing Discourses: an Exploration of Moreno Subject Formation in Oaxaca, Mexico" (2021). Dissertations and Theses. Paper 5785.

https://doi.org/10.15760/etd.7656

This Thesis is brought to you for free and open access. It has been accepted for inclusion in Dissertations and Theses by an authorized administrator of PDXScholar. Please contact us if we can make this document more accessible: pdxscholar@pdx.edu. 
Racializing Discourses: An Exploration of Moreno Subject Formation in Oaxaca, Mexico

$$
\text { by }
$$

Juan Salvador Sepulveda-Figuereo

A thesis submitted in partial fulfillment of the requirements for the degree of

\author{
Master of Arts \\ in \\ Anthropology
}

Thesis Committee:

Michele Gamburd, Chair

Charles Klein

Alex Stepick

Mrinalini Tankha

Portland State University

2021 


\begin{abstract}
Processes of Black racialization in Mestizo Latin America open a space to expose how subjectivities emerge and change while in tension with broader national ideas and transnational discourses. Morenos, typically dark skin individuals of African descent, inhabit the boundaries of mestizaje, Mexico's national racial ideology which emphasizes indigenous and Spanish ancestry. As a result, regional narratives subject morenos to racialization processes that align with the historical erasure of people of African descent, effectively excluding morenos from the nation. Nevertheless, morenos incorporate themselves into the regional and national narratives through various mechanisms and (re)formulations of established discourses.
\end{abstract}

I propose a conceptualization of "moreno" as a discursive figure that explores the processes of racialization and examines how morenos contest, internalize, and perpetuate it. In doing so, I draw on several theories. I draw from practice theory to contextualize how national discourse racializes morenos and the ways morenos subvert it - specifically looking at Foucault's ideas on the discursive tension between social structures and individuals. I also draw from Black theory, particularly Franklin Frazier's theorization of Black people as a dispossessed group and Thomas Biolsi's racial technologies. To frame these notions within wider regional and national narratives, I employ Stuart Halls' ideas on diasporic communities and their intersection with discourses of gender and nation.

In Mexico, as in various Latin American countries, Black represents a moving target. For this reason, I do not ask whether someone is moreno or not, but instead, I explore the local 
mechanism marking their bodies. In doing so, I delve into what constitutes a "moreno" subject position, what it might offer to Mexicans of African descent, and how it is in the process of continuous transformation based on historical and socio-political processes.

To arrive at these topics, I employed discourse analysis - paying particular attention to how morenos talk about themselves in local and regional settings and contrasting it to broader perspectives held by non-moreno communities regionally and nationally. I gathered my data through six months of ethnographic work in El Azufre, a small Afro-Mexican community on Oaxaca's coast. From August 2019 to January 2020, I engaged in numerous hours of participant observation, conducted forty interviews and two focus groups, and participated in a community-wide census. 


\section{ACKNOWLEDGEMENTS}

This research has been a journey of exploration as well as reflexivity. In trying to understand the Afro-Mexican experience and Afro-Mexicans relation to their bodies, history, and sense of belonging, I have continued a process in which I discover my own as a Latinx, Black, Gay man. Because of this, I find it incredibly important to thank and acknowledge the people who have encouraged, supported, participated, and stuck with me throughout this process.

First and foremost, I would like to thank and acknowledge the participation of the various collaborators in the community of El Azufre who made this research possible. They not only provided me insight into their daily lives but also made a space for me inside of their homes and families. Although for privacy reasons, I do not name them here, I cherish the connections and experiences I developed during my time in the community. Gracias por ser mis maestros.

Consecutively, this research would not have been possible without the support and encouragement of various professors at Portland State University. I am profoundly grateful to my advisor, Dr. Michele Gamburd, for being my mentor throughout these years, challenging my views, and being someone I always feel comfortable turning to. Likewise, I would like to thank and acknowledge my committee members. Without their knowledge, revisions, and reassurance, I would not have produced this thesis. Because of this, I want to thank Dr. Charles Klein, who propelled this research when it was just an idea for a course assignment and who showed me how accessible anthropological writing could be; Dr. 
Mrinalini Tankha, whose support and encouragement guided me throughout my time and challenges at Portland State; and Dr. Alex Stepick, who provided needed insight throughout my thesis process. I would also like to acknowledge my friend, mentor, and teacher, Dr. Lidia Marte from the University of Puerto Rico, who encourage me to further my studies, create, and live my most authentic life. I want to thank the Anthropology Department at Portland State for its support; the Newman fund and the Honors Laurels Scholarship facilitated my research endeavor.

I also want to thank my family and friends who provided me emotional support and helped me through this process. I want to thank my mom, Xiomara, for being the strongest and most hardworking woman I have ever met. I am who I am because of her. I want to thank my sisters, Yessica and Yerika, for always being there for me, listening, and encouraging my academic pursuits. I also want to thank my friend, Jay Lagunas, who was instrumental in the exploration of Blackness in Mexico. Thank you for the talks, laughs, and adventures; they kept me centered throughout my time at Portland. I want to thank my friend and colleague, Caro, who provided enormous input on Mexican culture and traveled with me to Oaxaca during those preliminary fieldwork months. And I also want to thank my friends Briana, Sneha, and Zach, who found a way to slip through my strict study schedule and made Portland a place I could call home. 


\section{TABLE OF CONTENTS}

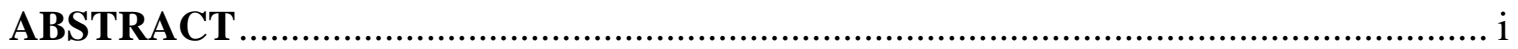

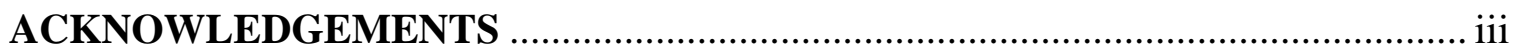

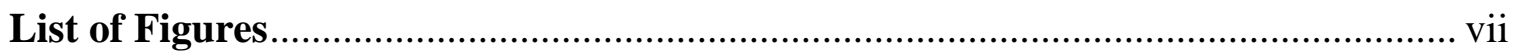

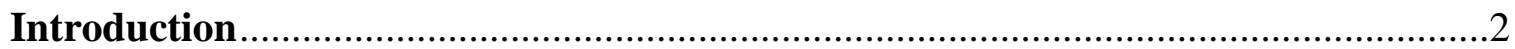

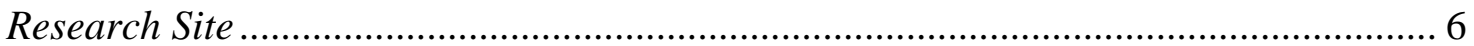

Theoretical Perspective \& Definitions ........................................................................... 7

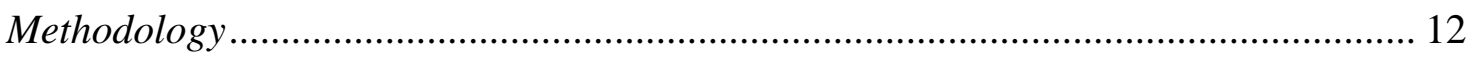

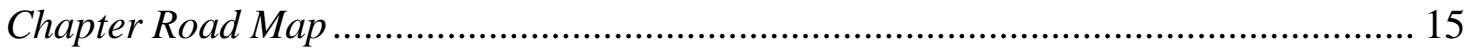

Chapter 1: Background and Literary Review............................................................19

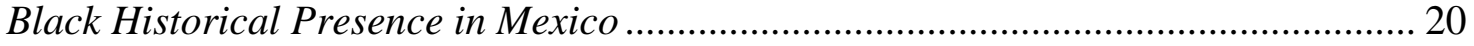

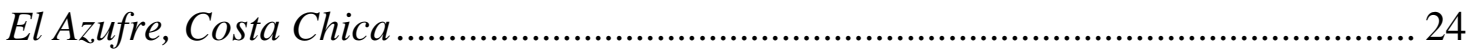

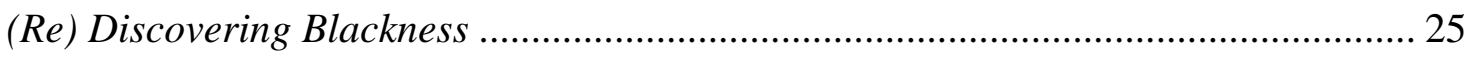

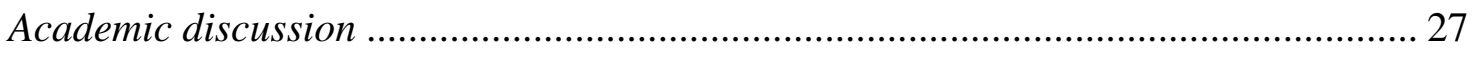

Chapter 2: Queer Ethnography: Engendered and racialized discourses in El Azufre

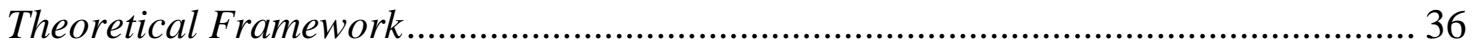

The Engendered and Racialized Researcher .............................................................. 39

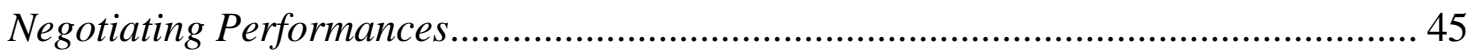

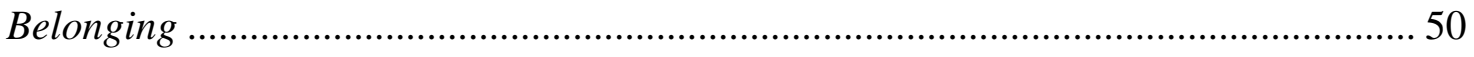

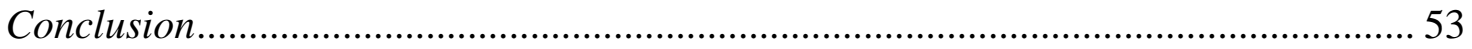

Chapter 3: Celebrating morenos? Discourses of Differentiation and Violence..........56

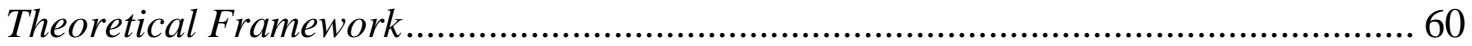

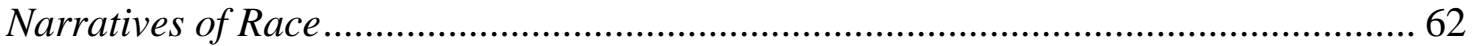

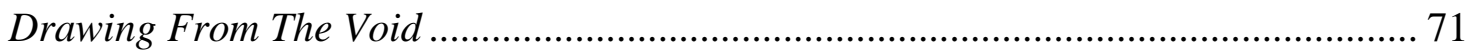

Individual Silences \& Perpetuating Narratives ......................................................... 77

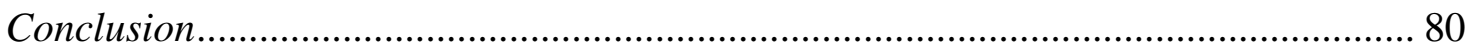

Chapter 4: (Re)Configuring mestizaje: Moreno subjectivity and Black consciousness

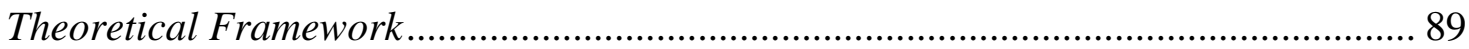

Historical Narratives of Racialization .................................................................. 91 
The New Mestiza is Morena .................................................................................... 94

Break from Morenos, The Mexican Black ............................................................. 102

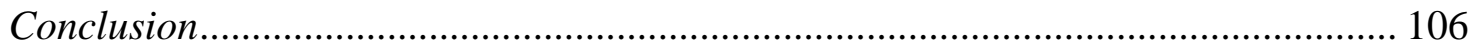

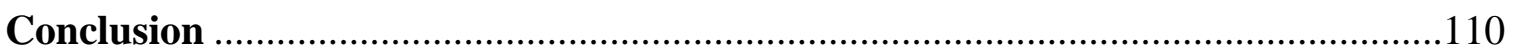

Implications \& Further research .................................................................... 114

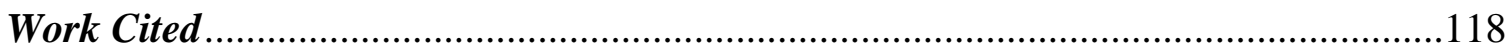




\section{List of Figures}

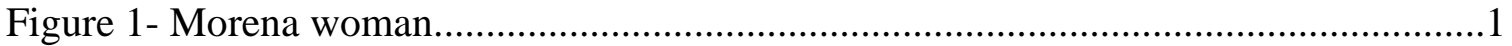

Figure 2 - Map of Costa Chica and El Azufre (Source: Google).........................................

Figure 3 - Morena woman...................................................................................18

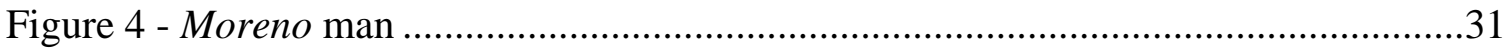

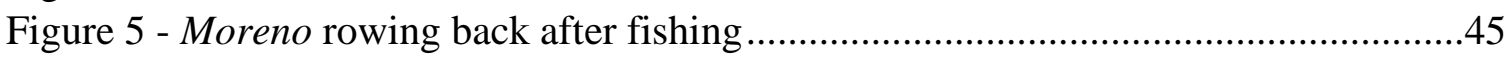

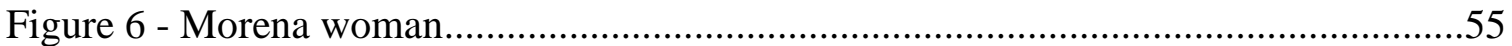

Figure 7 - Mestiza wearing Black face …………………….....................................62

Figure 8 - Portrayal of morenos by mestizo regional teachers .........................................65

Figure 9 - Group of girls with Mexico written on their foreheads....................................71

Figure 10 - A man from El Azufre holding a cartel of Vicente Guerrero ..........................74

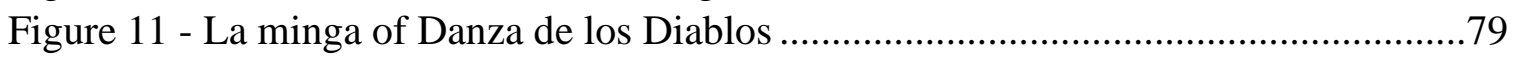

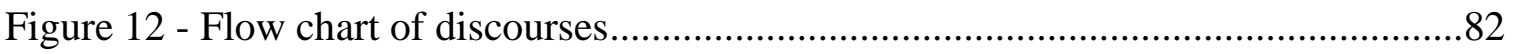

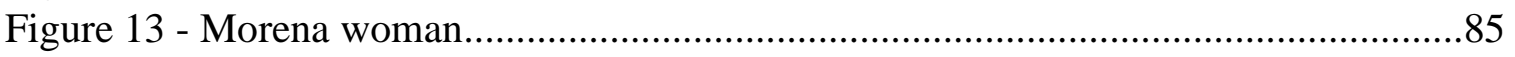

Figure 14 - People participating in "La entrega de la caja" ...............................................86

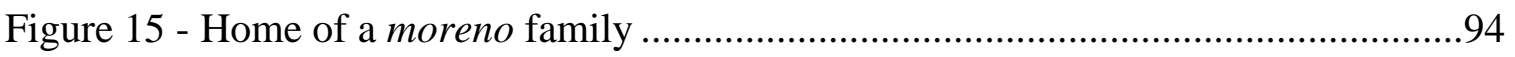

Figure 16 - Metate used to make corn tortillas ...............................................................95

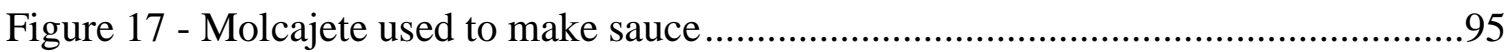

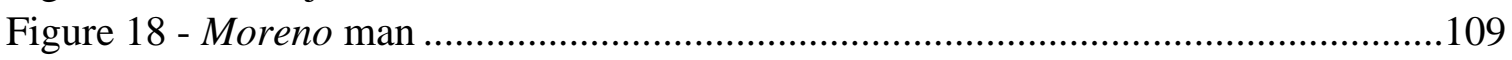




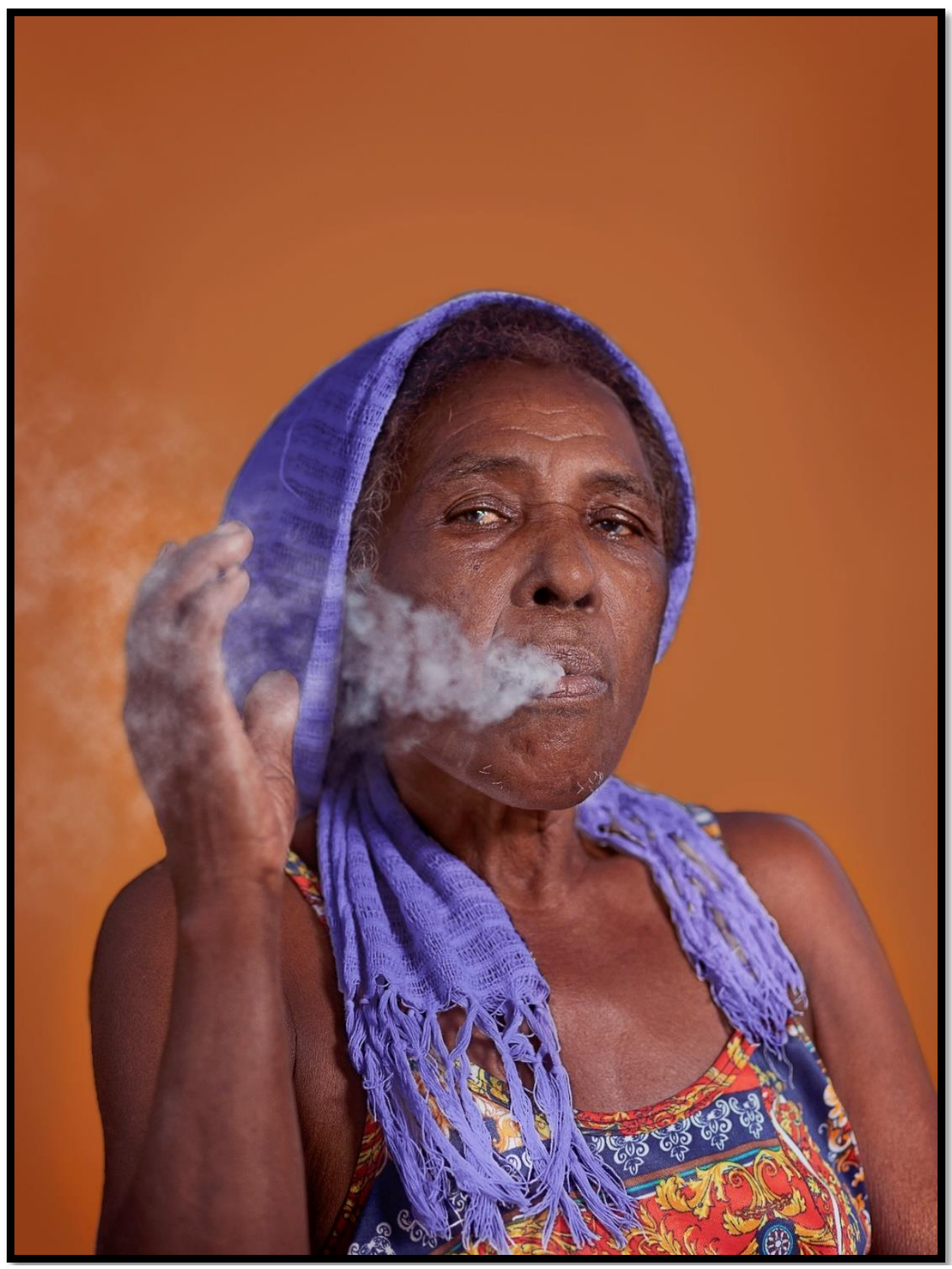

Figure 1- Morena woman 


\section{Introduction}

"No todo es lo que parece

Yo apenas tenia siete

cuando mi padre murió

Mi madre se la rifo

$Y$ fue caminando al frente

Se callo y se levanto

Pero nunca se rindió

Pero nunca se rajo"

"Not everything is what it seems

I had only seven years

When my father died

My mom turned cold

And as she leads the way

She fell and got up

But she never quit

She never gave up"

- Travieso de la Sierra-Mientras Siga de Pie

The sound of a corrido, Travieso de la Sierra, played loudly from the speakers of an empty taxi parked in front of a nearby residence. During festive days like today, residents often turned the volume to max on their radios, and various competing sounds filled the community of El Azufre. My shirt dripped with sweat. The temperature hovered around ninety-five degrees. Although I could walk ten minutes to the south and find the sea and walk five minutes to the west to find the edge of Rio Verde river, the day felt dry - like most days in the community. The gleaming sun brought out the colors of various balloons hanging from the electricity poles - red, white, and greenish blue. Similarly colored banners decorate the streets and local shops. A banner with the letters Viva Mexico overimposed in front of the colors of the national flag hung near the shop where I sat. The small 
store had a cement room with produce and items for sale and an open patio with a few chairs and tables.

Rafael, a mestizo teacher in his late 20s, had invited me to Pedros's tiendita - a small store in the middle of town. After watching the parade of the previous hours, Rafael and I and a group of local men had decided to head over to Pedro's for chelas (beers) and a conversation. We sat at the store for nearly half an hour. What started with a group of three men quickly turned into six. The open bottles of Corona piled up atop a table, and the drinks had started to go warm. The men sipped and occasionally spat on the ground as they order more beers.

"¿Pero y a quienes es que ustedes le dicen moyos? (Who do you guys call moyo?) ${ }^{1 "} \mathrm{I}$ questioned. Mexicans who have migrated to the U.S. use the term moyo to describe Black Cubans and African Americans. "Nosotros somos negros tambien! (We're Black too)," I continued. "No," Carlos, one of the men sitting next to me, replied, "Nosotros somos morenos (We are morenos.)." He stared at me as he pointed to his skin, as if to say, we are lighter than them. "¿Cuál es la diferencia entre moreno y negro? (What is the difference between moreno and Black)?" I pressed on. "Me caían gordo los moyos son muy agresivos (I didn't like African Americans. They are too aggressive)," interrupted another man, while Antonio, an older gentleman who along his wife, Carolina, became key collaborators throughout my research, elevated his voice and said, "Todos somos parejo (we're all the same)."

\footnotetext{
${ }^{1}$ The author translated all the material in the thesis
} 
On the evening of Las Fiestas Patria, the festivity celebrating the Mexican independence from Spain, a group of men of African descent discussed what Blackness represented locally. Perceivably, in the community of El Azufre, Blackness symbolized something foreign. "Negros" referred only to the dark Cubans or the African Americans in the United States. Azúfreños, although of dark skin tone, reserved the term moreno to describe themselves and, as I would eventually realize, who they are or, perhaps more importantly, who they are not. Based on the small interaction I had with the group of men, Azúfreños chose to locate Blackness somewhere far away.

Despite locals' distance from Blackness, anthropological research in the region foments racial differences. The idea that because of their "racial phenotype" and in few instances "ethnic differences," morenos, as people of African and often indigenous and mestizo descent in El Azúfre refer to themselves, constitute and visualize themselves as a discrete racial group. In this sense, researchers construe morenos as Black Mexicans. This categorization leaves unaddressed the mechanisms through which morenos separate themselves from Blackness and how they attempt to integrate themselves into the national narrative of mestizaje - the biological and ethnic amalgamation of indigenous and Spanish people.

Morenos experience what Stuart Hall describes as a crisis of identity $(1992,274)$. Because of their phenotypic features, for example, their dark skin tone, thick lips, and curly hair texture, and the spaces in which they live, morenos inhabit the boundaries of the national narrative of mestizaje and challenge the dominant history of the Mexican nation-state. 
Morenos' prominent African features expose the erasure of Africans in Mexican history and challenge the imagery of a lighter skin Mestizo citizen. The national discourse sustains this identity crisis by dichotomizing morenos' desire for representation and belonging and the national narratives that exclude them and subjects them to exclusion or "othering."

To move away from assumptions and broad ideas of Blackness, throughout this thesis, I explore the discourse and conceptualization of what residents of El Azufre refer to as moreno. I do this in three ways. First, I look at the racial technologies that produce a racialized subjectivity in the context of Mexico. Second, I discuss the discourse surrounding moreno subjectivity and how it differs from broader ideas of Blackness. And third, I explore how racialized individuals in El Azufre articulate, disarticulate, and are generally placed in tension with ideas of race and nationality. Because of this, I find it important to differentiate the terms. I use $\operatorname{moreno}(s)$ to refer to individuals and groups, and I use "moreno" when referring to the concept and discourse around people of African descent with evident African phenotypic features.

In this context, my research asks two main questions:

1. What mechanisms racialize Afro-Mexicans and constitute "moreno" as a distinct racial category?

2. How do individuals negotiate the racial label of "moreno" against broader assertions of Blackness? 


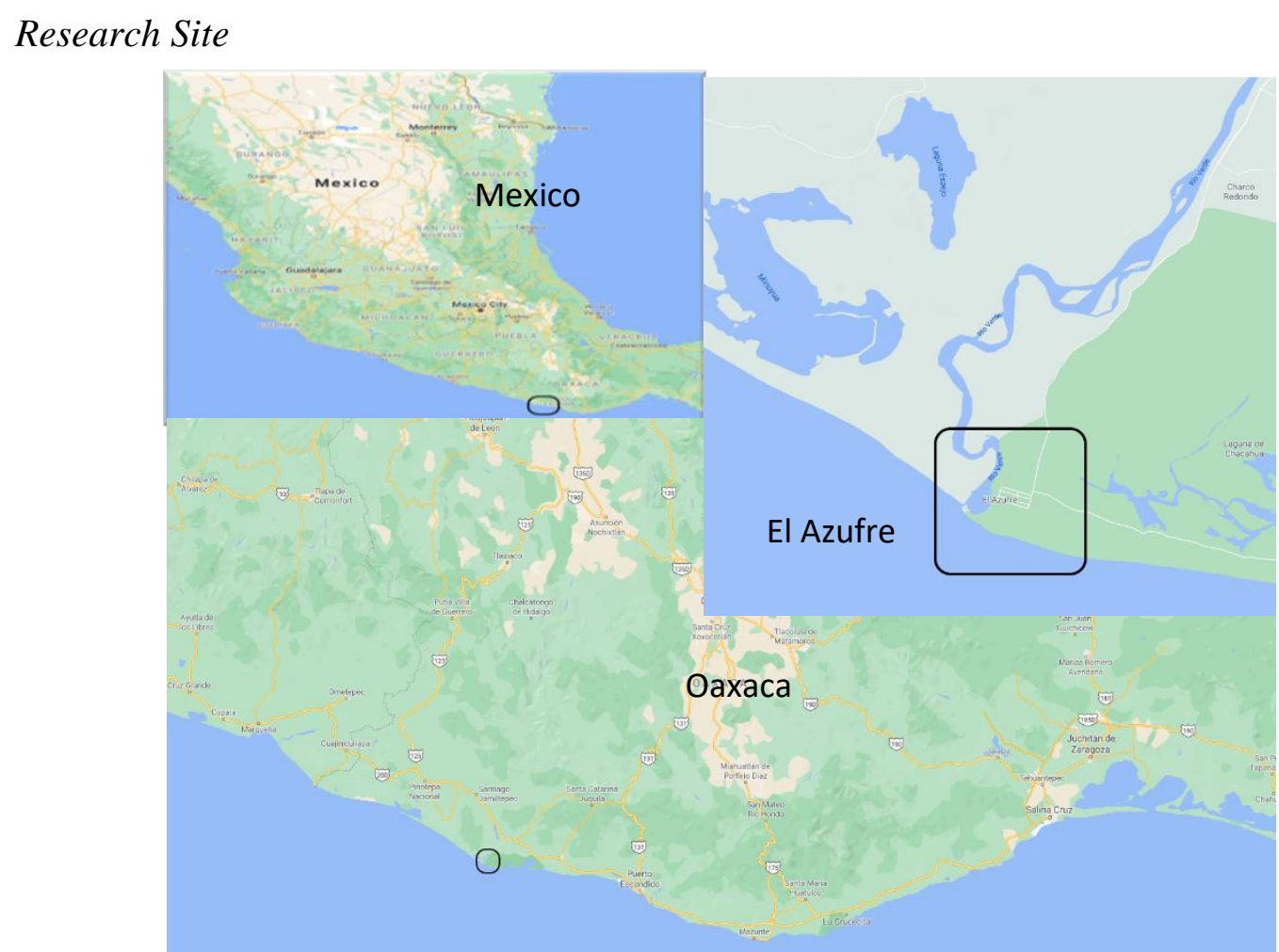

Figure 2 - Map of Costa Chica and El Azufre (Source: Google)

El Azufre belongs to one of the fifty-five communities composing the municipality of Villa de Tututepec. Geographically located in Oaxaca, at the edge of the Rio Verde river, it has the Pacific sea to its south, the Jamiltepec district to the west, Chacahua to the east, and the community of Charco Redondo to the north. The first fishermen settled in the area in the 1940s, and from there, the community increased. It currently has a population of around 450 people. The majority of Azúfreños work as fishermen and farmers, and through these activities, the people of the community sustain themselves.

I chose to conduct my research in the community of El Azufre as a result of my preliminary fieldwork trip in the summer of 2018. In the region, residents label El Azufre as a quintessential Black community, and various Oaxaquenos quickly locate Blackness within 
its community borders. Its unpaved roads and lack of labor diversity partially isolate El Azufre, which made it an interesting site to explore notions of Blackness in contrast to the Mexican national ideology.

I used the actual name of the community, El Azufre, in accordance with the confidentiality agreement I had with my collaborators. I chose to use the real name of the community rather than a pseudonym because any person with some knowledge of the region could deduce which community I reference. Throughout this thesis, I refer to various local events and activities. For example, El Azufre is one of the few Afro communities in the region that claims a sighting of the Virgin of Juquila and celebrates it, and the community is relatively close by to the community of La Consentida, where the Tututepec school event I discuss in chapter thee takes place.

In contrast to the community's name, throughout this thesis, I use pseudonyms to safeguard the security and confidentiality of my collaborators. In addition, I find it important to point out that, throughout this thesis, I blurred the information of my collaborators, slightly changing physical descriptions and locations to conceal their identity.

\section{Theoretical Perspective \& Definitions}

The last few years have seen a surge in the mobilization of people of African descent. Transnational initiatives like the International Decade of People of African Descent, which runs from 2015 to 2025, and tragedies, like George Floyd's death, have called renewed attention to systemic discrimination and other forms of violence. The surge in local activism and transnational conversations about the struggles of Black people has opened a 
space for academia to investigate Black consciousness and its relation to its nation-state. These activities and movements, which have cross national borders, are met with locally produced reflections and activism. In Mexico, various activities have taken place to provide recognition and secure opportunities for its Afro-Mexican population. As a result of some of these efforts, 2020 marked the culmination of a successful campaign by local civic organizations to include Afro-Mexican in the national census. These efforts are critical in Mexico, where the national narrative has erased people of African descent. 2018 - 2019, the years in which my fieldwork took place, marked an exciting point in this phenomenon. It coincided with broader international efforts to highlight people of African descent and regional and local movements to conscientize and prepare Mexican residents for the upcoming census.

Researching Afro-Mexican identity in a setting like Mexico necessitates a conceptualization of identity that considers Mexican mestizaje and the national erasure of Blackness. Because of this, my conceptualization of identity draws from Hall's idea of a “decentered positionality" $(1992,285)$. Framing the subjectivity of morenos through a lens of decentered positionalities allows me to visualize forms of identification as fragmented by classifications like gender, race, and socio-economic class. This theorizing permits imagining a duality between Mexican nationality and Blackness, which creates what Hall describes as a crisis of identity. To be attentive to the interaction between morenos and the discourses that racialize them, I analyze and frame this thesis through practice theory (Ortner 2006). Racializing discourses frame and constrain the subject positionality of people of African descent. In response, morenos also reformulate and transform these 
discourses through their daily actions. As I will explore further in the thesis, Mexicans of African descent face many barriers in acknowledging their Blackness because such acknowledgment would place them at odds with the Mexican national narrative. My analysis shows how Azúfreños deal with the duality through a decentered positionality that minimizes and erases Blackness and emphasizes mixture and Mexican attributes. In this way, I dislodge Blackness from any intrinsic characteristic based on phenotype and place it in a discursive terrain where it transforms and becomes localized.

As a result, I conceptualize race and processes of racialization through the theorizing of Omi and Winant. They define race as 'a way of 'making up people,' of creating boundaries, realignments, and collectivities.... [It is] a process of othering, categorizing and assigning attributes" $(2014,106)$. Thus, race and the processes of racialization configure mechanisms of differentiation and imbuing of meaning to certain people and groups.

Although all racial categories are discursive, unquestionably labeling someone as Black without contextualizing the term and how the discourse functions in specific localities leaves unexplored how national discourses have reconfigured Blackness in Latin American countries and how this discourse has transformed over time. As Thomas Biolsi states, "Race could not exist without both whites and blacks agreeing that there is such a thing as black and white" (Biolsi 2004, 403). And, in the case of Mexico, people have not agreed to such a thing. If anything, historically, the national discourse rendered Blackness nonexistent. 
Nevertheless, the concept of discourse invokes various definitions. This thesis pulls heavily from the Foucauldian conceptualization of the word. I define discourse as a system of thoughts, relations, and differentiation established between social processes in which the subject "is a plurality of possible positions and functions" (Foucault 1981, 116; See also 1972). Foucault's definition allows me to explore how people of African descent in Mexico articulate their positionality based on the various discourses found in the Mexican national narrative, local and regional rituals, and academic institutions.

Drawing from the various discourses prevalent in Mexico presents a problem. Where should I locate Blackness when the dominant discourse has erased it, and in which theoretical framework concerning the Black experience do I position my research? The latter has caused various debates over the last couple of decades as academics and civil rights organizations have struggled to categorize Afro-Mexicans. As a result of my conceptualization of positionality and discourse, I discard forms of Black theorization (suchas that of Herskovitz) that seek to unearth African continuities and subscribe to ideas of racialization. Through racialization, specifically Thomas Biolsi's race technologies, I address the conditions I observed throughout my fieldwork. Race technologies provide a template for contemplating mechanisms of differentiation and subject formation - through the technologies of stating, mixing, classifying, and spacing (Biolsi 2004). Biolsi employs these racial technologies to describe how a racialized subject formation emerges, reproducing power structures. For example, spacing's racial technology seeks to place individuals in discrete and mutually exclusive spaces and designate areas for each group. In contrast, to connect local processes of racialization within the Mexican national 
discourse, I draw on Hall's discussions of the discursive strategies employed by the national culture, like the nation's narrative, emphasis on origin, and national identity (Hall 1992, 293). By exploring the racial technologies used to racialized morenos and the discursive strategies used by the national culture, I attempt to conceptualize the social structures that constrain the discourse of "moreno."

As a result of morenos' distance from Blackness and my need to account for the national discourse, I position my research within discussions of the Black diaspora. As I will expose throughout my thesis, Mexicans of African descent reflect the prevalent themes of discontinuity and ruptures found in the Diaspora literature (Tiyambe 2005, 41). As Gilroy states, Afro-Mexicans, through their negotiation of positionality with the Mexican national narrative, possess an aspiration to nationality that defines the experience of diasporic communities $(1956,3)$. Although most researchers explore the notions of the Black diaspora in the Atlantic, through this thesis, I hope to highlight the Afro communities in the Pacific, as in the case of El Azufre, and how it represents one of the multiplicities of ways the Black diaspora manifests itself throughout Latin America. Similarly, enclosing Afro-Mexican experience within a solely Black theoretical framework risks leaving unaddressed the relational conditions that racialized Afro-descendants have with their indigenous and mestizo ancestry. Because of this, throughout the thesis, I pay close attention to how "moreno" racializing discourses are "constituted through relationships ... always dependent on a shared field of social meaning; ... [and] never produced in isolation" (Molina et al. 2019, 6). In this way, the ethnographic work presented holds as much 
relevancy to the Afro-diasporic fields of inquiry as it does to the fields of indigenous and Latin American studies.

With all this said, one question remains prudent to the theorizing of this thesis and to clarify where I locate my research. Who are Afro-Mexicans? Afro-Mexicans are Mexicans of African descent. Nevertheless, for this thesis's purposes, I find it essential to explain I specifically discuss the morenos of Costa Chica. People of African descent have incorporated into mestizaje by mixing with indigenous people and mestizos and moving out of communities designated as Black. Because of this, Mexicans racialize a portion of people of African descent as mestizo, especially when outside areas like the Costa Chica of Oaxaca, Guerrero, and Veracruz.

\section{Methodology}

To get to the themes presented in this thesis, I used a comparative field experiment design (Bernard 2011,106). I specifically use discourse analysis - paying particular attention to the discourse around morenos in local, regional, and national settings. I gathered the data through qualitative and ethnographic methods. From August 2019 to January 2020, I spent six months in the community of El Azufre doing participant observation. During that time, I conducted forty interviews, lead two focus groups, and participated in a community-wide census that drew 350 respondents - out of which I had access to the data of 150 surveyed participants. In addition, I utilize photography as a data collection method and a tool for representation. 
My principal methodology consisted of participant observation. I observed Azufreños in a variety of private and public settings. At the beginning of my fieldwork, I befriended an older couple who allowed me access to their daily lives and connected me with other potential collaborators. Access to these collaborators yielded relevant data regarding racial tensions and their effect on the everyday activities of Azufreños. I also attended and participated in a variety of local and regional events. Like many Catholic communities, El Azufre hosts various festivities and religious activities throughout the year. These range from small private gatherings to more significant celebrations like the festivities of the Virgin of Juquila. I also observed and participated in regional events and activities, like the Tututepec celebration of African heritage and the Tututepec municipality radio programs, Raices del Africa - African roots.

I conducted forty formal semi-structured interviews and twenty informal unstructured interviews throughout my time in the community. I used snowball sampling and relied on the access my main collaborators granted me to recruit other collaborators. The data are drawn from residents of El Azufre, residents of adjacent communities, and local and regional events. The various data sets serve to contrast the information I acquired. I took notes throughout the interviews, and, when allowed, I recorded and took photographs of the collaborators and events.

In addition to the interviews, I conducted two focus groups in the community of El Azufre. Both focus groups consisted of four people. Collaborators discussed how they perceive race and its implications on their life. I used the focus groups as an opportunity to validate, 
through triangulation, the data acquired through participant observation and one-on-one interviews.

My arrival in El Azufre coincided with a municipality-wide project on Afro-descendant communities. The teachers of the Tututepec school zone sought to highlight and present the Afro-Mexican presence in their district. Part of the project involved a census of the population paired with some qualitative questions. My involvement in the project, which was arranged by the teachers of El Azufre, allowed me to incorporate questions pertinent to my research in the questionnaire. As part for their research team, I surveyed 60 respondents and had access to the data of 150 respondents.

Lastly, photography served as an invaluable tool that allowed me to collect visual data in various settings. Photos function as a source of data throughout my research; images help provide a visual reference to the themes presented, and they allow for a representation of the community members of El Azufre. I show multiple types of pictures throughout the thesis. I placed posed portraits of community members at the beginning of each chapter, and I utilize candid photos I acquired at events and different activities. To shoot these pictures, I used a Cannon six mark ii.

I find it important to discuss the aspects obscured and highlighted by the photographs presented within this text. Because of the nature of photography, the images presented in this thesis further a discourse that places value in the construction of race based on phenotypical characteristics. Nevertheless, as I will explore throughout this thesis, it is important to underscore that El Azufre and the broader communities of Costa Chica 
construct race on racial technologies that are deeper and broader than phenotypic expression. Consequently, the discourse of "moreno" draws on abstract ideas of location, employment, character, etc. Similarly, morenos' physical appearance varies - different tonalities, hair textures, and features. Because of this, the photographs presented do not readily represent the myriad of characteristics present in the Afro-Mexican population. Nevertheless, these images highlight the Afro-Mexican people and provide a counternarrative to the erasure and exclusion people of African descent have to experience in Mexico.

\section{Chapter Road Map}

Throughout this thesis, I aim to explore and conceptualize the discourses surrounding morenos. To do this, I divide this thesis into four major chapters:

Chapter one, background and literary review, offers a brief historical look into Mexico's African presence, its representation, and contributions from colonization to contemporary times. This chapter focuses on Afro-Mexican figures, the disappearance of Blackness from the national discourse, and its eventual "unearthing" by national scientists. I use this chapter to provide a literary review and place my thesis within academic conversations regarding people of African descent in the Americas and Diaspora theories. This chapter also offers a glimpse into the historical narratives that have promulgated about people of African descent.

I wrote chapter two as a reflexive chapter titled "Queer ethnography: Engendered and racialized discourse." I situate my field work experience by exposing the mechanisms 
through which I became embedded in the community. This chapter explores the discourses that racialized and gendered me as I simultaneously did the same to my collaborators. Through reflexivity, I aim to allow for a critical lens of the limits and possibilities of my research. I enclose my research account around the religious festivities of Noche de Juquila, and I narrate my dynamics with the main collaborators of my research. I use these themes to present how racialized discourses, heteronormative practices, and gender performance affected my research. Heteronormativity framed the spaces and people I collaborated with and the people receptive to speaking to me; my "race" and gender performance left me belonging and excluded from different spaces.

Chapter three, "Celebrating morenos? Discourses of Differentiation," jumps into the local, regional, and national discourses that racialize people of African descent in the Costa Chica region. Throughout this chapter, I emphasize the social structures that constrain the moreno subjectivity while conceptually differentiating the discourse of "moreno" from Blackness. In this chapter, I discuss how racial technologies - the acts of stating, mixing, and classifying - form the subject position of moreno and fixes it on people with African phenotypic features. I also dive into how these racial technologies draw upon regional and national silences regarding people of African descent in Mexico. I frame this discussion through a school event in the community of La Consentida and Las Fiestas Patria, a Mexico independence festivity held at my field site.

Chapter four, "(Re)configuring mestizaje: Moreno Subjectivity and Black consciousness,” presents how people of African descent in Costa Chica (re)configure national ideas of 
mestizaje to situate themselves within Mexican group boundaries. In this chapter, I explore how these (re)configurations have historically allowed people of African descent to construct themselves as "moreno." In addition, in this chapter, I investigate the discourse surrounding the emergence of Black pride as I try to explore how the discursive figure of "morenos" changes in response to this new phenomenon.

Lastly, chapter five serves as a conclusion to the thesis. I summarize my findings and bring together the social structure described in chapter two and the (re) configuration of race explored in chapter three. At the end of this chapter, I speculate on emerging trends and future possible research topics. 


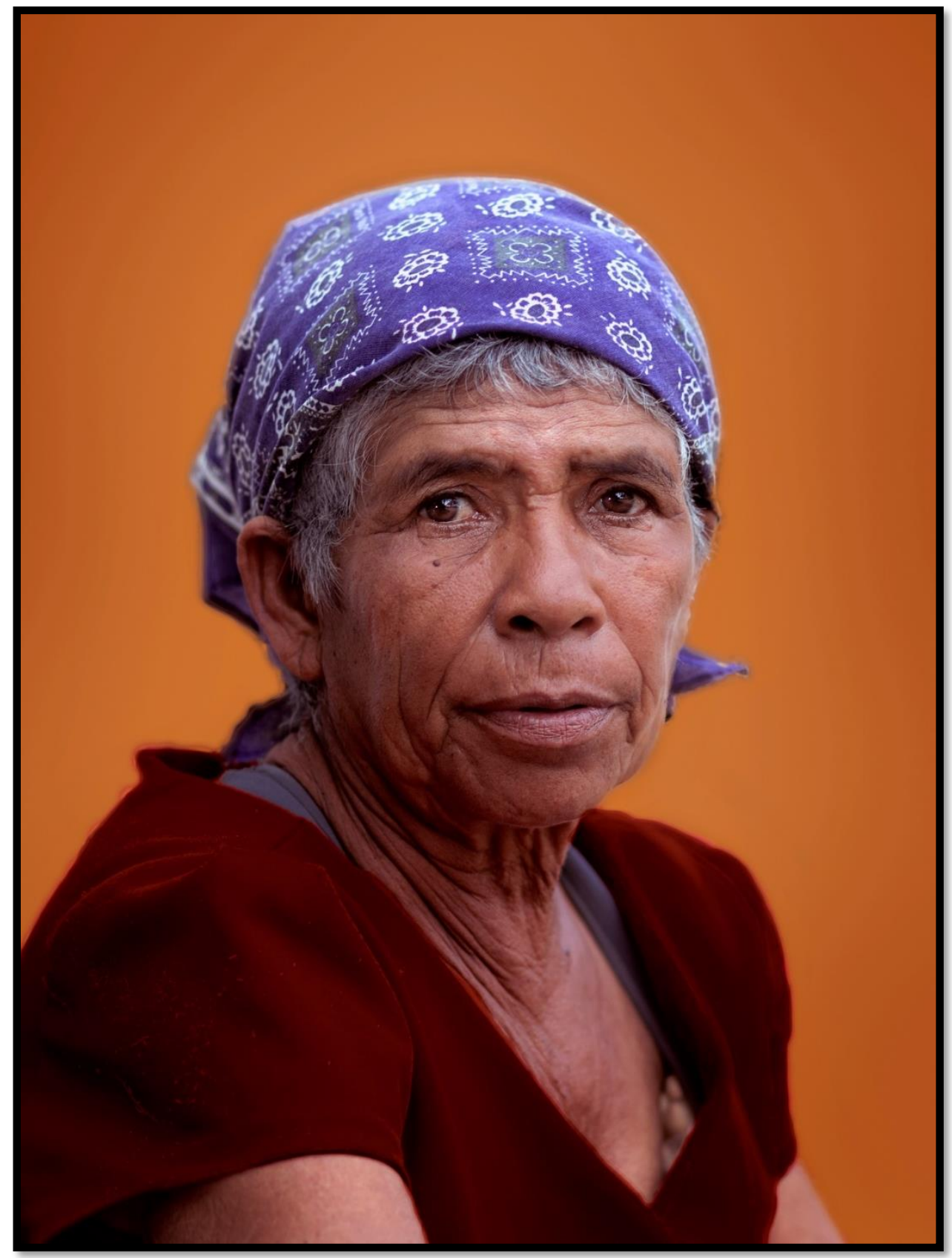

Figure 3 - Morena woman 


\section{Chapter 1: Background and Literary Review}

At the edge of El Azufre, near El Rio Verde, lies one of the community's most unique houses. At first glance, I did not see anything standoffish at the residence, but upon closer inspection, it is easy to discern the hanging bones that decorate the roof and the small children's shoes that adorn its outer walls. On the corner of the property, a sign reads, "Se curan males y enfermedades (cure for illnesses and aches)." Inside the gates, the open structure that constitutes the entrance of the house transforms the scenery. Mounted on the walls, hanged from the ceiling, and laid on mini altars surrounding the space, Miguel, the property owner, had placed bones of all shapes and sizes - enough to cover the walls. Near the center of the room, he had placed a tree-like figure with tiny fragments of bones hanging from it. Alonso practiced plant healing. Through his years of expeditions to collect herbs and plants, he had gathered numerous bones, and out of the material, he made figurines and peculiar objects. Through his activities and way of life, Alonso embodied local and regional knowledge. Although now, at an older age, he relied solely on fishing and healing, during his younger years, he had contributed to the community in active ways - serving as the town's "agente municipal (town's officer)." These days, many in the community considered Alonso a repository of knowledge. Because of this, I knocked on Alonso's door to talk about the history of El Azufre and the community's struggles.

When someone asks morenos from El Azufre about their history in Guerrero and Oaxaca's coastal towns, they commonly tell short stories about a shipwreck. Miguel recited those stories and added his details to them. According to him, some time ago, a ship crashed carrying African slaves in the docks of Puerto Minizo in the southern region of 
Chicometepec. In the story Miguel narrated to me, he presented African slaves as tall, with skin as Black as night but straight hair. In other stories, the appearance of the slaves lost emphasis, and the importance lay in the interaction the newcomers had with a local widow who owned and gifted the lands to the Africans.

Despite the differences in details, most origin stories share a common plot. The stories talk about Africans who survived the wreck of a slave ship and settled in the Costa Chica region, establishing their history in the space as relatively recent. Consequentially, this oral narrative omits slavery and the historical presence of people of African descent throughout colonization.

To contextualize my thesis in space and time and provide necessary background information on the historical processes and silences that have constituted the moreno experience, I explore the historical presence of people of African descent in Mexico. I contextualize and situate the experience of Mexicans of African descent with transnational pan-African efforts. I dive into the contemporary fights for pride and recognition currently fought by Afro-Mexican civic organizations. I use this brief historical account to offers an overview of morenos' experiences and provides context to the historical place morenos have in the nation.

\section{Black Historical Presence in Mexico}

When I first arrived at El Azufre, I introduced myself to the local teachers. Wanting to know about Mexican history from the school curriculum, I borrowed two of the principal books used as historical references in La primaria and tele-secundaria, elementary and 
middle school in the United States. The community does not offer a bachillerato (high school). The first book I borrowed, published by Planeta DeAgostinai, had the title Gran Historia de Mexico Ilustrada 1521 - 1750. The second book, Arma la Historia, was produced by the Secretary of Education in 2010. In a predominantly moreno town, neither of these historical books talked in detail about the African presence in the country and its subsequent impact on the nation's construction. The absence of Africans in the history books surprised me since, in the first century of colonization, the Spanish introduced around 60,000 African slaves to New Spain, the name given to the Mexican territory through colonial times (Aguirre-Beltran 1944, 414). The social structures of the time divided the socio-economic strata by a sistema de castas (Latin caste system) that strictly classified people of African descent legitimizing their presence in the society.

Africans who arrived in the colony during those first decades had varied experiences. However, although the vast majority of Africans came as slaves and lived out their lives in bondage, various accounts nuanced the diversity of experience people of African descent faced in New Spain. Different sources of information about the colonial period highlight how Africans arrived as personal servants to Spaniards and as military men as part of the conquest, like Juan Garrido, Juan Valiente, and Juan Roque, Africans who aided Spain in the conquest of the Americas (Restall 2000). In addition to the Black conquistadores, slave had various experiences in New Spain as they rebelled against Spaniards and escaped their captivity. Most Africans and their descendants experience conditions of brutal violence during the period of colonization. Because of this repression, slave revolts occurred regularly in the territories beginning in 1537 (Davidson 1966, 243). Yanga, an African 
maroon slave, in the $17^{\text {th }}$ century formed a palenque (free African town) in the region now known as Veracruz and subsequently gained legal rights upon negotiations with Spanish officials (Davidson 1966, 249). To counter the erasure of Africans from the national narrative, I highlight the immense quantity of African slaves present during this time. By 1650 , New Spain had forcibly brought in at least 120,000 slaves into the colony, a fact which made Spaniards and 'criollos' (Spaniards born in America) wary of their numbers to the extent that they requested the lowering of licencias, permits the Spanish crown granted for the importation of slaves (Vaughn 2013, 18). The combined figure of African slaves and Afro-mestizos in the territory by 1650 hovered at 135,000 (Davidson 1966, 237)

Researchers have produced multiple works on the presence, treatment, and history of African slaves in Mexico's colonial period (see Aguirre-Beltrán 1972; Bennett 2003; Palmer 1976). Africans undoubtedly formed a component of the social fabric of New Spain. For various reasons - rape, the economic incentive for slave owners, freedom, etc. - miscegenation between the Africans, indigenous people, and Spanish transpired. In the latter case, mulattoes and pardos born from the miscegenation of an indigenous or Spanish mother and a slave father would take the mother's free status, making miscegenation one way towards freedom. These differentiations mattered. According to Aguirre-Beltrán, the Spanish crown subjected mulattos to a form of tribute that did not apply to the mestizos $(1972,172)$. Naturally, the racial mixture also exposed the caste system's permeability, which relied on genealogy and physical appearance. It allowed some mulatto slaves to run away and, depending on their physical characteristics, pass as indigenous or even criollos (Valdes 1944,189). 
By the beginning of the $19^{\text {th }}$ century, a socio-economic and political conflict started to occur in New Spain. International conflicts had regional repercussions; since the church was the financial institutions of the time, it sent Mexico' liquid capital to Spain to aid the war with Great Britain. Jose Bonaparte became Emperor of Spain, which spurred separatists movements. During this struggle, various Afro-Mexican heroes like Vicente Guerrero and Jose Moria Morelos, who according to Aguirre-Beltrán characterized as mixed with African ancestry $(1972,165)$, joined the efforts to separate from Spain. The war of independence ended in 1821. Mexico separated from Spain, and in 1829 Jose Maria Morelos became president and officially abolished slavery. Ending the implementation of the caste system serve to further emancipate New Spain from Spain (Jimenez-Ramos 2009, 77). The end of slavery and the caste system meant that race's old superficially static configurations became increasingly loose.

A lack of information concerning the roles and spaces occupied by Afro-descendant people after the end of the colonial period exists. Subsequent years in the region saw spurts of violence as different governments rose and failed and foreign conflict took place, such as the 1840s separation of Texas and 1860s French occupation of New Spain. Nevertheless, historical figures like Antonio Alvarez highlight how people of African descent still played a role in creating the nation. In the mid- $19^{\text {th }}$ century, he led a revolution against Mexican dictator Antonio Lopez de Santa Anna.

At this juncture in time, most studies and written work of people of African descent in the region stop. Very little information remains on their experience during El Porfiriato, the 
historical period in which Porfirio Diaz ruled as a dictator. By the mid- $20^{\text {th }}$ century, after the end of Porfirio Diaz's dictatorship, the push towards a Mexican identity and the idea of the cosmic race materialized the notion of mestizaje, placing it front and center and completely erasing people of African descent.

\section{El Azufre, Costa Chica}

Alonso's origin story has some foundations in historical events. Until early in the $18^{\text {th }}$ century, before the port of Acapulco became prominent, El Puerto Minizo functioned as the region's principal port. Thus, African slaves could have arrived in the region from there. According to Aguirre-Beltrán, during the $17^{\text {th }}$ century, as Spain lowered the number of asientos, licenses to transport slaves, the Pacific's flotas, which Spain traditionally banned from transporting slaves, started smuggling them into the region (1972). In addition, the Spaniards had brought African slaves with them to fight the indigenous population and establish haciendas. Despite these overarching facts, scholars have little information on exactly how and in what period Africans and their free descendants populated and created settlements in the area (Lewis 2012; Vaughn 2001).

When it comes to El Azufre and the various communities along the lower half of the Costa Chica region, Alonso talks about fishermen. He mentioned how families, like Los Ochoa and Alvarado, arrived to the coast to fish. The abundance of robalo fish allowed for the establishment of a community. Alonso estimates the families founded the community

around 1940-1945 with families from Collantes, Charco Redondo, La Boquilla de Chicometepec and Cuajinicuilapa. Contemporarily, residents call the space these original 
families came to inhabit "El Azufre Viejo (the Old Azufre)" because a military intervention in the area, hoping to hinder the presence and establishment of communities, burned the first houses down. The few families that stayed organized, relocated to a nearby area, and founded the community naming it El Azufre because of a local deposit of sulfur in the area.

Multiple factors allowed El Azufre to remained relatively isolated, primary among them the community's remote geographical location. El Azufre is in the delta where the Rio Verde joins the Pacific Ocean. The river lies to the south, and the swampy terrains of the Lagunas de Chacahuas lie to the east. The easiest way in or out is a dirt road that connects El Azufre with Charco Redondo and San Jose del Progreso, but the terrain is rocky and tends to flood during the rainy season.

\section{(Re) Discovering Blackness}

In 1946, the Black presence (re)entered academic and political circles in Mexico. In his pioneering work, La población Negra de Mexico, Aguirre-Beltrán discusses the historical existence of people of African descent. Manual Gamio, the Secretary of Government and National General Archive, asked Aguirre-Beltrán to assess the degree to which AfroMexicans constituted an ethnic group (Vinson \& Vaughn 2005, 53). Aguirre-Beltrán found that the Afro-Mexican population did not possess enough distinctive characteristics to represent a separate ethnicity. He believed that Afro-Mexicans would soon merge with the mestizo and indigenous people (Aguirre-Beltrán 1972, 290).

To explain his findings, Aguirre-Beltrán explored how miscegenation had historically integrated Afro-Mexicans into the population. After a few mixed generations, African 
slaves started to resemble their Spanish captors or their indigenous neighbors (AguirreBeltrán 1972, 277). Although Spanish officials delineate genealogy during the colonial period, after Mexico's independence, the clear genealogical lines dividing one caste from the next started to blur. A percentage of the Afro-Mexican population integrated into the soon-to-be-established ideology of mestizaje.

Blackness (re)emerged in 1974 with the study of the non-indigenous ethnic minorities conducted by the INAH (Instituto Nacional de Antropologia y Historia) which aimed to study foreign populations in Mexico. Subsequently, and because of this study, in 1980, a program titled "La Tercera Raiz (The Third Root)" began to study and present the contributions of people of African descent in the country - although with a focus on the colonial period. Simultaneously, the Costa Chica region started developing ground-up initiatives that led to the formation of Mexico Negro by Father Glyn Jemmott, a Trinidadian priest, and a group of residents from the Costa Chica region in 1997. That same year, they celebrated the first Annual meetings of Black Communities, drawing attention to people of African descent in the region. The event garnered enough attention that in 1998, in Oaxaca's legislative body, legislators signed article $16^{\text {th }}$ of the Oaxacan Constitution granting recognition and rights to people of African descent (Gonzalez-Estrella 2012, 68). These events coincided with broader transnational conversations like the 1989s UNESCO African Heritage Program, aiming to create exchanges between Africa and the Americas.

Since the 1990s, an explosion of initiatives and organizations has focused on communities of African descent in the region of Costa Chica. In 1999, the town of Cuajinicuilapa 
unveiled a museum for the Afro-mestizo culture. During the early 2000s, residents formed additional organizations, such as AFRICA AC, an NGO in the community of Morelos seeking to foment Black pride. By the latter half of the first decade of the 2000s, through the combined efforts of civil organization, various programs and activities started taking place, like Afro-Mexicans' first forum in 2007, the Red de Organizaciones de Pueblos negros de Oaxaca Y Guerrero 2008 (The network of organizations of Black towns in Oaxaca and Guerrero), and the First Cultural Festival of Black Towns in 2011. These movements and events led to the inclusion of Afro-Mexicans by the Instituto Nacional de Estadistica y Geografia (National Institute of Statistics and Geography) in the preliminary census of 2015 and their official inclusion in the census of 2020. These movements have made headway in the recognition and aid of Afro-Mexican communities.

\section{Academic discussion}

The erasure of Afro-Mexicans from the national narrative meant people of African descent had to be rediscovered and reinserted as a field of study. The works by Aguirre-Beltrán laid the foundation for that reintroduction. Aguirre-Beltrán's writings on the colonial period, The Slave Trade in Mexico (1944) and La población Negra de Mexico (1972), solidified an interest in this inquiry line and influenced national policy. Through his work on slavery, Aguirre-Beltrán located people of African descent in a distant past. Through his ethnographic work in Costa Chica, with his book Cuijla (1958), which claimed the remaining Afro-Mexicans held minor ethnic differences from the mestizo population, he 
framed subsequent studies on communities of African descent - situating them in the past or in the process of amalgamating into mestizaje.

Thus, historical and ethnohistorical inquiry define local and foreign research on Blackness in Mexico. These studies have described slavery during the first centuries of the territory (see Aguirre-Beltrán 1944, 1972; Bennett 2003; Palmer 1976). They have also tried to dispel notions of submissiveness on the part of African and mulatto slaves by highlighting slave rebellions and escapes (See Davidson 1966). Some historians have also charted the evolution and decline of slavery (Valdes 1944). Wittingly or otherwise, local and foreign academic efforts mirrored state-sponsored studies displacing Blackness to the past.

In contrast, contemporary socio-cultural work focuses on various issues facing the Afrodescendant community. Out of this research, I locate two branches of inquiry. Although here I present them as composing discrete issues, these branches relate and overlap. The first line of investigation deals with ethnicity, and here we find studies on the ethnic differences of people of African descent, interethnic relations, and NGO ethnicizing. After Aguirre-Beltrán's research, which claimed Afro-Mexicans lacked an ethnicity, it became politically essential for the procurement of rights to locate ethnic differences in the AfroMexicans. Pushed by advocacy and the prevalent idea of African continuity, community members and academia started looking for ethnic variations in food, dances, music (see Ramsay 2004). Interethnic relations and conflicts between Mexicans of African descent and indigenous people also took center stage (see Quecha 2016, 2017). Here, researchers produce a body of work looking at the spaces of inclusion and exclusion between Afro- 
Mexicans and indigenous people. Academics have also focused on the organizing of NGOs and the ethnicization of people of African descent (see Gonzalez Estrella 2012; Iturralde 2017; Quecha 2015: Weltman Cisneros 2013).

The second branch of theory looks at racial formation in Afro-Mexican communities. These inquiries into racialization tend to follow two separate routes of thought. First, the African continuity route which seeks to uncover remnants of African traditions in presentday Afro-communities (see Green et al. 2007) and unquestionably classifies AfroMexicans as Black (Vaughn 2013). Second, the contextual race route which explores how socio-historical circumstances racialize identities and construct race based on local processes. Depending on the researcher, these processes are inter-ethnic (see Lewis 2000, 2001), in contrast to state sanction programs (see Sue 2009; 2010), and in relation to broader national ideas of mestizaje (Miller 1961; Wade 2005).

I position this thesis in the latter. I contextualize the racialization process experienced by morenos as historic and subjected to local phenomena. Nevertheless, my perception of these processes of racialization differs from researchers like Lewis, Sue, and Wade in how I conceptualize “moreno.”

Lewis, for example, conceptualizes "moreno" as the mixture of indigenous and Black and as an identity that, through its connection with indigeneity reinserts people of African descent into the national narrative. Nevertheless, this conceptualization limits her purview of current racialization processes. And, it downplays the symbolic violence experienced by morenos. It pushes to the peripheries the current Black pride movement materializing in 
the area as a response to systemic racism, designating it as the work of cultural promoters. Similarly, Sue's approach to racialization, emphasizing who people perceive as moreno based on physical phenotype entangles the racial process and leaves little room to explore how the discourse of "moreno" functions outside of physical characteristics.

In contrast, my conceptualization of "moreno" as a discursive figure accounts for these scenarios. In the Mexican and Latin American contexts, "moreno" means different things to different people, and Black phenotypic expression functions as a moving target; thus, "moreno" is a place holder for representations of ideas, spaces, histories, disruptions, phenotypes, distances, and silences. Visualizing "moreno" in this way allows for an exploration of African descent that accounts for the separation from Blackness in the community and the recent push for self-categorization as Black.

With that said, my perception of racial dynamics in the Costa Chica region have changed from when I first started my fieldwork. The next chapter explores my experience during this time and the negotiations that took place as I negotiated my racial and gender positionality with my collaborators. 


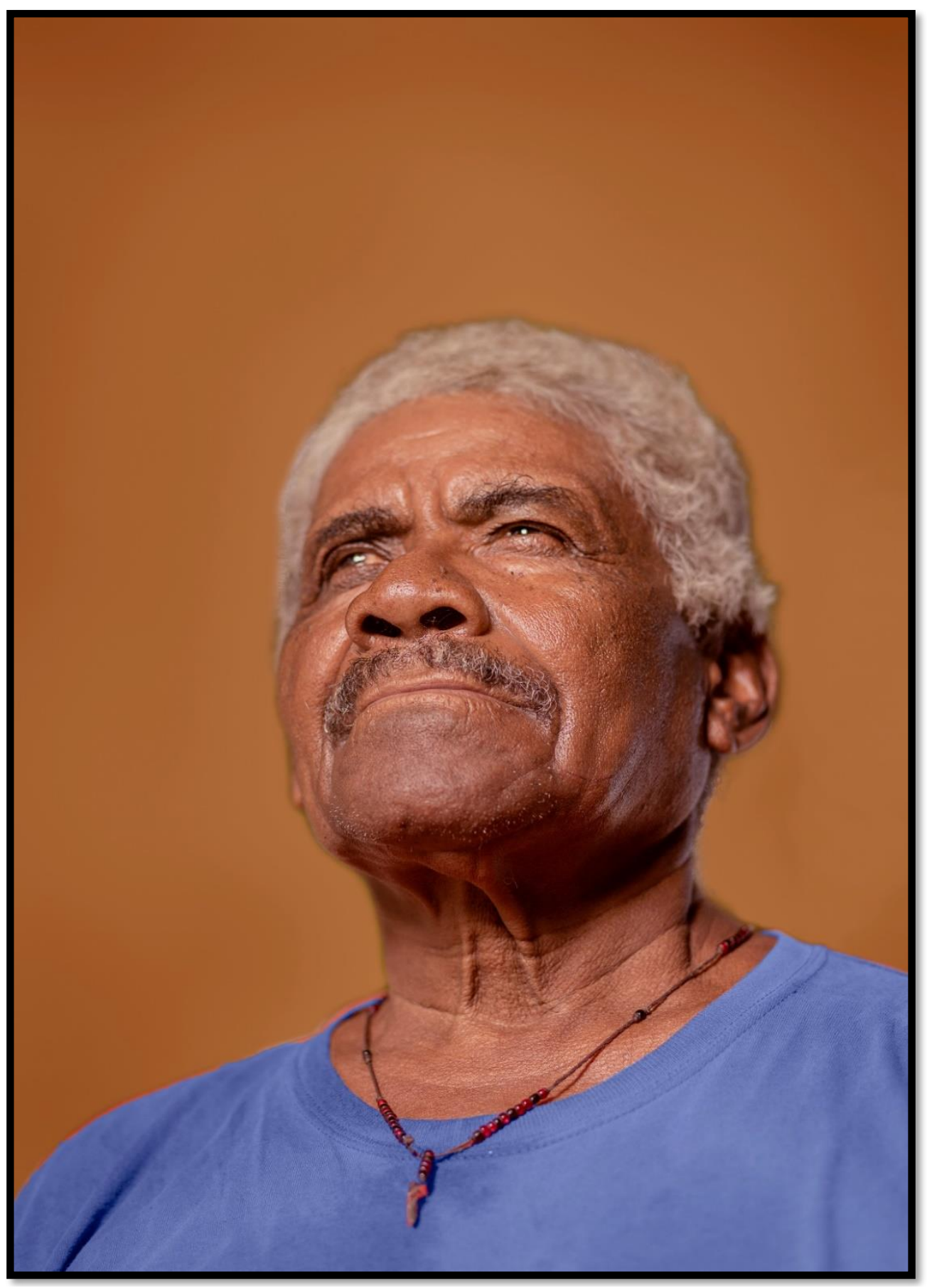

Figure 4 - Moreno man 


\section{Chapter 2: Queer Ethnography: Engendered and racialized discourses in El Azufre}

The sun had already set, and lights from different houses illuminated the night. On most other evenings, silence would permeate the community, with just pockets of people scattered, intimately talking to one another, but tonight, people celebrated Noche de Juquila, a festivity meant to mark the appearance of the Virgin of Juquila on the clouds on top of El Azufre. Neighbors from the adjacent communities and small vendors occupied the streets; in the center of town, food, laughter, and music filled up the Catholic church. By the time the clock struck seven, everyone had started to dance. The calenda, a gathering in which women dance in celebration, had begun to make the rounds through the town. Women and a few gender-nonconforming people paraded by in bright, colorful gowns, dancing and drinking, while men stood in groups comfortably at the side, laughing and staring. I had spent a month in my field site when the three-day-long festivities started. The weeks before, multiple locals had talked to me jokingly about los chismes (the gossips) surrounding the sighting of the Virgin and teasingly encouraged the night as a time for me to find a morra (slang for girl) to dance with and have some intimacy.

As the calenda danced its way around town, women of all ages moved to the rhythm of a live band, shaking their bodies while maintaining flower arrangements on top of their heads in perfect balance. In the middle of the crowd, I saw Sandra dancing. She had a pink bandana covering her forehead, a white long-sleeve shirt, and a knee-length blue skirt. I had met Sandra during my first day in El Azufre. She seemed distant, her speech sharp and direct, as many women did during those first interactions in the community. Unlike those 
early days, today's festivities had everyone in a cheerful mood. The whole community boomed with activity. I thought about heading over and starting to dance, but as I walked toward the crowd, I heard someone shouting at me: "Candela!" Sandra's husband and a group of men from the community stood at the side of the street, talking, laughing, and drinking Victoria, a brand of national beer. Sandra's husband, Victor, a slim man with a long face and dark brown skin, had taken a liking to me, and every time he saw me, he would exclaim candela and laugh. In Puerto Rico, where I am from, candela refers to the act of setting something ablaze or beating someone up, but I never figured out what it meant to Victor. I assumed he picked up the word while en el norte, in the United States. After a few weeks, we shouted candela at each other's sight. As I walked closer to the group of men, I could hear Victor asking, "¿Qué hubo we? ¡Tienes que sacarte una a bailar! (What's up, man? You must get a girl out to dance!)" I acknowledge him and reply with a quick and easy "soon," as I stopped, laughed, and awkwardly ran off to get a drink.

Similar to this cultural festivity, gender demarcates everyday activities and spaces in El Azufre. Like La Calenda, a dance where women are the primary participants, settings like churches, bars, and other social gatherings follow distinct gender norms. In the community, I often saw women together in their homes, walking around town, and tending to their work or leisure activities - all highly gendered. In contrast, men tend to stay outside, setting their trasmallos (gill nets) at the beach or tending to the crops, if they have land, and spending their leisure time at bars or playing sports. "Transgressors," like the gender-nonconforming people dancing in la Calenda, are rare. 
It did not take me long to find a Corona. With a drink in my hand and no clear place to go, I wandered around the streets, thinking. Times like these exemplify my overall struggles, external and internal, in the community. I wanted to reach out to Sandra, talk to her, hear her story. I wanted to look for LGBTQ people and talk about their experiences in El Azufre. But, as it usually happened, men pulled me towards their spaces, which, although welcoming and open, came bombarded with insinuations and vulgar jokes I had to navigate around. "Mira que rica esa morra (look how fine that girl is)," they would comment. "Esos muslos (those thighs)" as they singled out some girl or women. Sometimes this chatter represented innocuously small interruptions in the conversation; other times, the whole chat revolved around these themes. I readily found myself part of these conversations, and just as often, I had to joke the discussion or question away, or excuse myself when they expected a reaction of me. It only took me a week into my fieldwork to wonder how awkward I most likely appeared to local men, like Victor, avoiding their gaze and their insinuations. For how long could I deflect? For how long would a few replies like "Yo soy un hombre serio (I'm a serious guy)" or "Que me den un terreno y me caso (if they give me some land, I'll settle down and marry)" suffice?

I had come to El Azufre understanding my position as an outsider, but with the comfort that, in contrast to other foreign anthropologists, my Black skin and fluency in Spanish would provide me access to this Afro-Mexican community. Practice proved more nuanced as I simultaneously "fit in" physically with the local population while my accent, ways of acting, and queerness marked me as foreign. In hindsight, the fact that I somewhat 
resembled residents made my inability to perform and articulate local forms of gender and sexuality stand out.

Fieldwork is daunting. I found it hard to navigate a foreign space and acquire access to people while choosing which aspects of myself to disclose. However, all ethnographers face this question as they construct a field site persona. As a gay anthropologist, I pondered these questions as I stepped into my project. I decided, for security reasons, to step back into the closet. As a result of this, aware of the need to fit into male spaces and acquire access to the community, I modified my gender performance - I toned down, to the extent that I could, my mannerisms. I tried speaking with a more resonant voice and controlling my intonation. I tried to appear more masculine; I dressed in looser clothes and grew my beard. I sought to portray a more locally palatable version of myself through these changes - a version I believed residents would find familiar.

Nevertheless, gender norms delineated the spaces in which I belonged and those I did not. I tried unsuccessfully to fit in. In a way, I felt exposed. I did not belong - not with the men laughing, drinking, or teasing one another, not with the women, as they danced, sang, and clapped joyfully, and not with the gender-nonconforming residents who, because of my self-presentation to the general community, I had to approach carefully.

This chapter contextualizes my ethnographic experience as an Afro-Latino, gay and feminine presenting man by emphasizing the negotiations and tensions present during fieldwork. I do this to situate my writing and research within an embodied field of vision attentive to race, gender, and nationality. My fieldwork experience became entangled on 
various discourses as collaborators gendered and racialized me while I simultaneously projected my racial ideas on them. To explore these discourses, I divide this chapter into three sections; the first explores local perspectives on gender and race and the tensions between my perspectives and those of my collaborators; the second speaks to how national discourses on race and gender impacted my field work, and the third considers how, through familial bonds, I found a sense of belonging within my community.

\section{Theoretical Framework}

Ethnographers commonly negotiate different aspects of themselves to gain access to participants (Gardner et al. 2006; Ulysses 2002). While I assumed I would not be the exception, I did not fully grasp how gendered dynamics would affect the spaces I frequented. Mexican nationality has deeply embedded masculine ideals (Paz 1972, 10), and consequently, Mexican gay men tend to negotiate gender roles carefully (Carrier 1995). I encounter these dynamics during my research. As a collaborator I befriended mentioned after I finished my fieldwork, my laughter, the way I danced, and the intonation and flow of my voice unwittingly gave me up as different from the community's masculine standards. My dark brown skin color effectively made me inconspicuous among the AfroMexicans of El Azufre, while my gender performance marked me as "other." Because of this, throughout my time in the community, I was effectively queer - my gender performance differed from the norms placed on men in the spaces I occupied.

The prevalence of these situations forced me to reflect on their underlying significance and their immediate impact on my fieldwork and subsequent analysis. I did not embody 
queerness in my sexual desires, as locals did not honestly know who I slept with, but rather in my inability to perform heteronormative expectations. I performed queerness "in a context other than sex" (Warner 1993, vii). By utilizing the word Queer here, I describe and refer to actions which, although in my case unconscious, "dramatize incoherencies in the ... relations between chromosomal sex, gender, and sexual desire" (Jagose 1996, 3). A reflection of my fieldwork experience necessitated that I seek out such a framework. Thus, through this chapter, I use Queer as both a descriptor for my fieldwork experience, as I encountered broader social norms and expectations of how a man behaves, and as an inductive critical lens from which I can analyze and present the data I acquired. Theorist Annamarie Jagose emphasizes queer theory's ability to highlight the fluidity of gender expression (1996). By showcasing, as I did in the introduction, the extent to which gender restricts every aspect of the community and my experience in it, I hope to highlight the challenges that male ethnographers with feminine characteristics face against hegemonic gender norms.

As I problematize my experience in the field, I draw on Black Queer ways of theorizing to represent my queer experience and its intersections as it entwines with aspects of race, ethnicity, and nationality. For example, Mexican society views its men as Machos and, in contrast, attributes feminine characteristics to foreigners. National origin and race can sometimes construct people as feminine and open spaces for homoerotic teasing and verbal assaults, as we see in Hoffman's account of his Mexican fieldwork (Hoffman 2006, 16). In my case, because of my physical resemblance to locals, residents from El Azufre expected and held me to rigid standards of masculinity. Hoffman's account, which highlights his 
interaction with Mexican fishermen, highlights how he found a way to playful subvert the fishermen's verbal assaults. Unlike his account, my case had other implications. Local's teasing regarding my sexuality took a sinister dimension for me since they opened issues of safety.

As I mentioned, I met the expectation of masculinity held at my field site by performing in masculine ways while unconsciously producing feminine characteristics. Local standards of acting and my gestures and movements highlighted inconsistencies that queered me even as I attempted to play into heteronormative behaviors. Thus, while I presumed to subscribe to social standards and adapted and performed Mexican masculinity to the best of my abilities, critical gestures and behaviors marked me as "other." By employing the concept of performativity (Butler 1993), I aim to address engendered social constraints while exploring the performative conduct that constituted and made residents read my body as gay.

Lastly, because my fieldwork experience became marked by "the closet," I emphasize the negotiations of disclosure, whether verbal, physical, or intuitive, during my time in the community. Framing my experience in such a way allows for a visualization of my agency and constraints. Discourse then represents both the physical and attitude changes I wished my collaborators read on my body and the disjuncture from social gender norms that commonly accompanied me. The idea of disclosure allows me to explore how my foreignness and perceived education level clouded my collaborators' vision and ability to read me. I use James McDonald's concept of "queer reflexivity" to describe the disclosed 
and hidden qualities ethnographers employ to adapt to their field sites (2016). I also use Decena's idea of the "tacit subject" to analyze how, through collaborative efforts, individuals assume, dislocate, and hide their sexual orientation (2011).

\section{The Engendered and Racialized Researcher}

As women danced around in la calenda, tall, distorted figures comically chased after them. These figures, los monos, wore long skirts and bright colored shirts. Los monos, men wearing masks resembling monkeys, chased after the twirling women as they danced away, laughing. Los monos provide a sense of comedic distraction and ridicule for the spectators. In a sense, this ongoing theater of dances and imagery offers a glimpse into social transgressions and how the community handles them. Like los monos, I became entangled in the community's social structure, which placed me in a theater of open secrets, rumors, and insinuations. Similar to them, I also hid an aspect of myself. I wore a mask in an attempt to perform masculinity, distance myself from queerness, and hide my sexual orientation.

My discomforts within the community forced me to look in unexpected places for data and a sense of belonging. Because of this, I gravitated towards Carolina, a matriarch I met during my first days of fieldwork. I provided her attention, and in return, she gave me a home away from home. After a few minutes of walking throughout the festivities, I decided to head towards the church, where I knew I would find her sitting down and enjoying some food. 
Earlier in the day, before the festival took place, I had spent some hours at her home. The days before, I had shown interest in learning how to cook one of her dishes, and earlier that day, we had gathered ingredients for her to teach me how to prepare pozole costeño, a Mexican dish made with corn and poultry or meat. I got to her place at noon. By the time I arrived her husband, Antonio, had already left for work. As soon as I arrived, she reprimanded me for arriving late. She waited all morning and quickly showed me the pot she had separated for the pozole and some breakfast for me. On days like today, I appreciated meeting her and Antonio. The bond that we formed informed and, to a certain extent, framed my time in El Azufre. I became entangled in the community and acquired a semblance of what it meant and felt to be an insider through the "politics of love" (Dominguez 2000, 361).

Physically resembling locals came with some advantages. That morning, Carolina and I went from shop to shop in the community, getting all the ingredients we needed. "Andas por ahi con uno de tus hijos (you're going around with one of your kids)," one of the shop owners we visited said jokingly - alluding to how much time Carolina and I spent together and the physical resemblance, mostly skin color, between Carolina and myself. The bonds I had formed with Carolina, aided by my resemblance to her, facilitated my integration into community life. The racial discourses of our respective regions, which characterized me as a mulatto from the Caribbean and them as Afro-mestizos, had not materialized. At that moment, because of my phenotype and language, residents viewed me as a moreno or at least a moreno-adjacent. Deepening my voice slightly, I replied, "Me tiene aqui cocinando (She has me here cooking)." 
As an Afro-Latino, I started my field work contrasting my racial experience and that of morenos. I found various similarities in the discourse of mestizaje and the distancing from Blackness prevalent in our respective countries. Puerto Rican discourse has also employed various adjectives to describe people of African descent and distance them from their Blackness: moreno, prieto, triegueno, and even indio. Because of this, when gazing at morenos, I came to project my ideas of Blackness on them. I discarded the distance from Blackness they continuously expressed and the one my upbringing had subjected me to and labeled them as I contemporarily label myself - as Black Latinos. But it does not take much to find Blackness in the Hispanic Caribbean - it is in the language, food, music, and other cultural productions. So, I could not perceive the extent to which the Mexican national discourse had erased Blackness in this region, or, even more, how morenos used indigenous ancestry and lived experiences to lay claim to Mexican identity. The fact that no indigenous communities in Puerto Rico remain made these dynamics foreign to me. The ways morenos and I recognized each other's similarities clouded the ways in which we realized our differences.

When we finally arrived back at the apartment, Carolina guided me through the process of preparing the dish and often interrupted her cooking to give me directions: "Llamate al compadre (call the godfather), so he can chop the wood for the stove" she yelled. Rarely did Carolina have me do physically strenuous work, often opting to call on someone else for such tasks. I grabbed the machete, slightly annoyed she thought I could not do the job, and started chopping. "You have to stir the corn with the cal, para que se ponga tierno (so 
that it softens)," she continued later. Most of the day we spent like this, Carolina giving me instructions and showing me how to make her family recipe for pozole.

As we waited for the corn to boil, we sat down in front of her house, watching the vendors prepare for the festival night. As they came and went, she gave me details, if she had any, of them and other passers-by. Today, the festivities made the roads busy with people, and she would comment here and there, "Ese es un putito, un maricon (He's a little fag)." "Y no le puedes hablar mucho porque se pone agresivo cuando esta borracho (You can't speak to him a lot because he gets aggressive when drunk)." On a particular occasion, when a trans woman walked in front of her house, she commented, "Si vas a hablar con el (if you're going to speak to him)," you can bring him here. You do not want to go to his house; he is robust. He might rape you," as she laughed. However ill-informed, I took note of her comments. I wanted to know how to approach LGBTQ people and the spaces where I could interact with them without chismes (translate) from the community. I did not condemn her comments at the time, nor the subsequent derogatory looks she would throw at visibly feminine men.

Carolina looked at gender non-conforming people and marginalized sexual orientations with disdain. She used pejorative and dangerous stereotypes to describe people in the queer spectrum. The term "putito," for example, has a double meaning. Mexicans use the term to reference gay men and also to suggests promiscuity. So, gay men do not just embody a "deviant sexual orientation" but rather an oversexualized lifestyle. Likewise, like the mockery of los monos, her comments ridicule what she perceives as contradictions in the 
gender performance of queers - "he is a little fag who gets aggressive when drunk" and describing a trans woman who portrays femininity as robust.

Carolina exemplified both comfort and exclusion through various degrees. But, our dynamic worked. I withheld my sexuality; she ignored my feminine mannerisms. Through that negotiation, I found myself with semi-comfort and belonging, and she found herself with company and help.

Because of these narratives, I found it hard to open up about my sexuality. Thus, the closet framed my interactions with collaborators. It established a web of characteristics and values to which I wanted to associate myself, a strong, respectable, knowledgeable morenoadjacent man, and several elements I wished to leave at my community's entrance, that of a gay, feminine, harassable foreigner. Secrets held those desires in place, and, like Decena argues, "the closet is a collaborative effort," an effort that, through its negotiation and proper repeated execution, sustains relationships (Decena 2011, 349). I unwittingly entered into a contract of sorts with Carolina and my close collaborators. In our unspoken agreement, I had to keep secrets and modify my appearance and gestures to fit into the community while my collaborators held those rules. Carolina never commented on my femininity; she did not ask about my potential sexual partners, and when talking about feminine men, she left me out of the conversation. In this way, we both sustained our relationship. Our dynamic became tacit not in her acknowledgment and silence towards my sexuality but the understanding that, whatever the cause, my inept gender performance would remain unaddressed. 
Nevertheless, although I did not explicitly let my collaborators know about my sexual orientation, people in the community assumed my sexuality in other ways, like the spaces I occupied. My comfort with Carolina meant I spent less time with men my age. Also, I occupied spaces mostly populated by women, like Carolina's house, church settings, and community groups. My presence in them did not go unnoticed. In contrast, my limited time playing sports, a prominent activity for men in the community, or spending time with local young adults also denoted certain information. Disclosure took place through the spaces, activities, and people I frequented.

Although all ethnographers create a field site persona to gain access, trust, and remain safe, these dynamics are especially salient for queer ethnographers for whom social norms turn even baseline expectations of gender upside down. As in my case, race played an intricate part in my inclusion in community life. Nevertheless, my "racial proximity" to morenos and my insider status remained in tension due to my flawed performance of masculinity.

As a gay man, I felt palpable pain from the mental and discursive gymnastics of entering the closet. Not only did I have to monitor and censor myself, but I also had to shed behaviors that had come to comprise my day-to-day life in the States. I needed to restrict and regulate interactions with local members of the LGBTQ community. I also needed to nullify expressions of my sexuality. And, in addition, circumstances limited my contact with the outside world. 


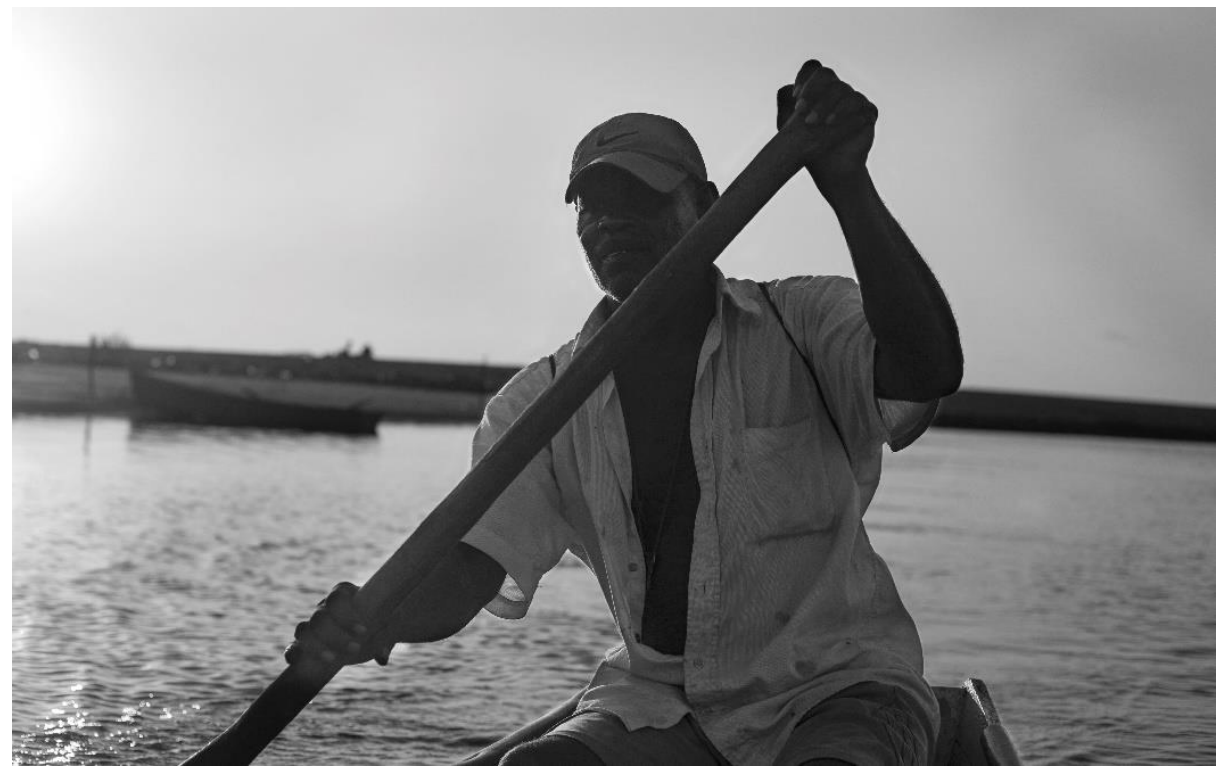

Figure 5 - Moreno rowing back after fishing

Back at the festivities of Juquila, as I walked the community observing the vendors and the activities happening around, I heard Victor's “Candela!” He had caught up to me, and after a few exchanges of words, he invited me to go to a small party nearby. Although Victor seemed relatively happy throughout the day, he opened up about the struggles he had faced during our walk. His dad had died a few weeks before, and he, like many people in the community, struggled financially. Nevertheless, he seemed optimistic that his fortune would change. Despite the hurdles, today he celebrated, and, at this moment in time, he seemed slightly drunk.

We arrived at the party in the pitch black of night. However, the brightness of the festivity illuminated this side of the community. The event took place underneath a palapa 
(translation?). The hosts had covered the ceiling with white balloons and white ribbons and scattered tables around the space. Women mostly attended this celebration. Band music blasted all around, and the moment Victor and I sat down, somebody came over offering some Coronas. A few minutes in, a visibly trans woman took one of the few men, an older gentleman, out to dance. I recognized the older gentleman as one of the town's drunks. Without a shirt and with his pants almost falling off, the old man stumbled his way across the dance floor as his partner twirled him around. Teasingly, they danced, fought, and piggybacked each other. I had not met the woman before; she had a slim composition, brown skin, a red blouse, and blue jeans. She seems to enjoy herself, and as she danced and jokingly roughed up the older man, I could hear the spectating women laughing so hard it almost competed with the music. In between the laughter, one of the women approached me and took me out to dance. Victor and I spent a couple of hours there, drinking, dancing, and laughing.

Months later, a key collaborator would inform me Victor made his mind about me and my sexuality at that party. Up to that point, my performance of masculinity had seemed to produce enough ambiguity that I did not get readily classified by Victor as gay. Nevertheless, that night, my laughter, way of dancing, and other minuscule but repeated characteristics solidified Victor's evaluation.

We left the party late in the night. Yet, because of the festivities, people still walked outside, enjoying themselves. The church committee had organized a dance that would start at 11 pm and go through the night. As we returned to the community center, Victor decided to 
stop and sit down to get a beer. I sat down next to him and ordered a corona. A few feet away, on the other side of a table, sat Antonio, laughing and eating. By the way he acted and shouted, I could tell he had already drunk a lot. We made eye contact, and as he saw me sit, he started yelling: " ¡Mi hijito! Tienes que comer bien. ¡Los plátanos te tiene débil! ¡Mucho marrano! (My son! You must eat well. Eating plantains keeps you weak! Eat lots of pork!)". I looked at him and smile. He made inappropriate remarks while drunk. But the drunker he got, I found it harder to understand and avoid him.

Antonio's character mirrored broader national ideas of how a Mexican man behaves and appears - as strong, courageous, and sexually active. Local narratives of what a man represents and how a man behaves mirror national notions of masculinity. Octavio Paz, a prominent Mexican writer, exemplifies these themes when he stated,

The Mexican man can bend, can bow humbly, can even stoop, but he cannot back down, that is, he cannot allow the outside world to penetrate his privacy. The man who backs down is not to be trusted, is a traitor or a person of doubtful loyalty: he babbles secrets and is incapable of confronting a dangerous situation (Paz 1972, 30).

Gender norms draw from and reinforce Mexico's machista national narrative, describing a strong and unbendable man, and construct men who deviate from these characteristics as untrustworthy and deceitful. Nevertheless, Paz's writing did not reference Mexicans of African descent, although mestizos and "criollos", denomination for Spaniards born in the Americas, figured prominently. Likewise, the general national discourse erased morenos 
from the national imaginary. Despite this, moreno communities, like El Azufre, place importance on notions of masculinity and the demarcation of gender. Perhaps, these notions even function as mechanisms through which morenos integrate themselves to the national imaginary.

I seldom interacted with Antonio when he decided to drink heavily. But, in this situation, I could not help it. Victor accompanied me, which meant I could not just leave. A few minutes later, Antonio had stood up and mumbled out a few things Victor and I could hardly make out. He stumbled and dizzily moved about as he slurred his words together. The moment he caught my eyes, he said: "Mi hijito, tienes que dejar esas paterias, no puedes decepcionar a tu familia (My son, you have to stop with the "faggetry," you can't disappoint your family)." I looked at him and pretended I couldn't understand him. After a few minutes, I got up, and I made my way out of the shop.

I had a good grasp of how to navigate one-on-one situations. But Antonio publicly calling me out in front of other collaborators and strangers placed me in a vulnerable position. Antonio did not use his statements as a way of teasing or joking, or at least it became hard for me to take them that way, but rather a declaration of how he felt about and viewed me. Such outward expressions gave me an understanding of how he perceived me and the way I handled myself.

Victor followed me; although drunk himself, he wanted to make sure I got back to my house safely. I tried with varying levels of success to let him know I did not intend to drink more. Suddenly, he stopped and told me, "A mi me han preguntado si tu eres gay (Someone 
asked me if you're gay)." He paused and stared at me for a moment as if waiting for a reply. When he saw I had not said anything, he continued, "Is there a Spanish phrase missing here? I've told them not to mess around with you." "Que tu eres bien, que respetas, y si alguien se mete contigo, yo me meto (That you're reasonable and respectful, and if anyone messes with you, I'll jump in)." I stayed quiet, kept walking, and, unsure of how to respond, barely managed to formulate a smile. As we walked, Victor suddenly stopped again, unzip his pants, and started to pee right there in the middle of the unpaved road without any warning. I kept walking. When we arrived at my house entrance, we spent a few moments saying goodbye, then he took my hand, kissed it, and left.

Alcohol opened a space in which many rumors and insinuations came to light. Although residents hardly spoke to me directly about my sexuality when they were sober, they felt comfortable and uninhibited enough to express their doubts when inebriated. This happened as I interacted with the community and spent time with Antonio and Victor. On otherwise regular days, my sexual orientation and gender performance rarely become a point of explicit conversation. Antonio asked me about women, and we would make jokes here and there about his masculinity as he talked about possible sexual encounters. In this way, my inability to perform masculinity correctly had various repercussions in the ways people addressed me, what they said about me amongst themselves, and the access I had to certain potential collaborators.

While drunk, a few residents openly question my sexuality. They fully displayed the open secrets and the incongruencies of the dynamics we had established at these moments. 
Perhaps such instances underline the limits of the tacit subject as a framework for the closet. Alcohol opens a space in which the closet becomes a point of open conversation and in which those engulfed in the dynamic, like in the case of Victor, approach me with unclear intentions.

\section{Belonging}

Simultaneous inclusions and exclusions exemplified my time at $E l$ Azufre. My approach to residents revolved around matching my need to acquire good ethnographic data and having a support group. However, a few hours before I head out to the festivities at Noche de Juquila, after Carolina and I finished cooking and sat down to eat, the bonds and spaces I had formed with them, with residents, and the community, in general, became evident.

Carolina and I had finished cooking the pozole, and she had started setting the table. She expected Antonio to arrive at any moment, and sure enough, not ten minutes after her declaration, I spotted Antonio on his bicycle, making his way towards the house. Hijo! he exclaimed with joy, for all his reservations about me, I felt, during times like this, he felt happy to see me. "Let me go by some chelas" (beers) he commented as he saw us setting the table. With Antonio, I could never tell how bad things with his drinking could get; I could not imagine Carolina's struggle with his drinking, but they did not seem like something consequential during these moments before the inappropriate looks and remarks. I figure I would just sneak away after he had some drinks. Likewise, although differently, I also had to manage Carolina's worries; "No te metas ahi (do not go there)," she would tell me about el desmadre (mess) that usually accompanied the dance the 
community had programmed through the night. Carolina and Antonio worried about me. Although she and Antonio knew the community had stayed relatively calm for a few months, they would caution me, "No salgas si esta muy de noche (don't go out if it's too dark out)." From time to time, I would hear Carolina say, "Those people sell drugs, don't go near them," or "you have to be attentive when you're walking around with your stuff." In their way, they also worried about our future interactions; "Antonio dice que no vuelves mas (Antonio says you won't come back to the community)," Carolina would mention from time to time. She worried our bonds would break once distance intervened.

Carolina and I set the table, and I started digging in when Antonio arrived with Carlos, an older man. Carlos looks tall and skinny and has a dark brown skin tone. I had interacted with him a few weeks prior; he took the time to teach me about corn and how the community produces it. From time to time, we would sit down to talk; he had become one of the first residents to push back on me. "Donde estan tus papeles (where are your papers)" he would question me. "Tu te ves Dominicano (you look Dominican)" he would comment here and there as I felt compelled to explain my Dominican heritage while highlighting the normalcy of Black Puerto Ricans. Carlos questioned everything from my rights to do research to the remuneration he and other collaborators should have for assisting me. I had told him from the beginning my budget did not allow me to contribute to my informants' lives that way, and, after a few backs and forth, he had settled, at least superficially, on the idea. 
To his surprise, Carolina invited him to eat, and he joined us at the table. As I took my first few bites, I realized the pozole was delicious; I had my reservations while preparing it, but it all came together. We talked about our families as we ate. I mentioned how I would enjoy cooking this for my mother once I returned home. They seemed interested in my family background, so I told them my story, upbringing, and mom's effort to sustain and maintain the household. Antonio curiously asked about my dad and how he fit into the picture. I explained how he did not since a single mom had raised me. Carlos jumped in. "No me sorprende (it doesn't surprise me)," Carlos mentioned as he took a spoon full into his mouth. "Is there a Spanish phrase here? There's something about you that would make me think that" he continued as he shrugged his comment off. From what I understood, he felt something odd about me, and that piece of information provided him with the context he needed. The table got incredibly quiet, and when I asked him what he meant, he just reiterated what he had previously mentioned. Antonio and Carolina attempted to change the topic of conversation, and after a few minutes, we returned to one of the most discussed topics in the community, religion.

After everybody ate, I laid on the hammock, digesting, while Carolina took everything to the kitchen, and Antonio showered. Every time I tried washing the dishes, she would tell me: "Dejalos ahi, no te preocupes (Leave them there, don't worry)." By that point, I knew better than to try to go against her will. I watched her as she cleaned the table. Antonio had gone to the bathroom to shower for the festivities, and Carlos and I sat close by, not saying much. Eventually, he broke the silence and said: "Ya eres parte de El Azufre; tu eres como 
familia (You're already part of El Azufre; You're like family)." "If you need something, we're here for you."

\section{Conclusion}

"De moreno a moreno de donde eres (From a moreno to a moreno, where are you from?)" An onlooker asked me during my first trip to the communities of Costa Chica. From my first instances in the region, residents started to classify me as a moreno. In a way, these same assumptions played out as I traveled back and forth from Mexico and finished my research. In my fieldsite, my race and gender performance created spaces of inclusion and exclusion. As a result of my skin color, fluency in Spanish, and character, morenos partially racialized me as one of their own. In part, this allowed me to create familial bonds with the people of the community - a fact that gave me both security and access.

By classifying me as a partial moreno, residents racialized me. They concurred that, even if just partially, I had a similar socio-historical background to them. In turn, I also racialized them. I racialized them as Black and ascribed to them certain ideas of what Blackness represented for me. As an Afro-Latino, race occupies a discursive terrain characterized for its presence and importance in everyday scenarios as its absence and minimization. For me, Afro-Puerto Rican culture and history is found everywhere while simultaneously minimized and displaced. In the context of Mexico, morenos have different social circumstances defined by their erasure from Mexico's history and national narrative. When I arrived at the field, I employed various racial technologies, like classifying and spacing (Biolsi 2004, 406). I racialized morenos as Black, located them in the discrete communities 
of Costa Chica, and unintentionally lost track of the ways morenos partially construct their local racial positionalities.

On the other hand, gender and the parameters of masculinity have always framed my life in strict ways. Nevertheless, I had not foreseen the extent to which gender performance would frame my experience. My gender performance positioned me as queer and contrasted my presence to that of local men. I consciously tried to perform masculine by changing my voice and appearance while unnoticeably misperforming gender. These repetitions in gender performance positioned me outside of the parameters of masculinity defined by my community and greatly impacted my interactions and access to collaborators.

Similarly, silences and secrets framed my experience in the field. The interactions I made while at the field site filtered themselves through the proverbial closet. These dynamics of secrets and disclosures tensed the connection I had with collaborators. However, the closet became a collaborative effort sustained by the dynamic I had developed with my key collaborators. They dismissed questions about my inept performance of masculinity, and I kept my sexuality hidden.

Despite mismatched ideas of race and inept performances of gender, the bonds of familiarity I formed with my informants safeguarded me and gave me all the access I needed to the community. Through their affection and solidarity with my work, I found myself feeling welcomed and able to gather the information I needed for my research. 


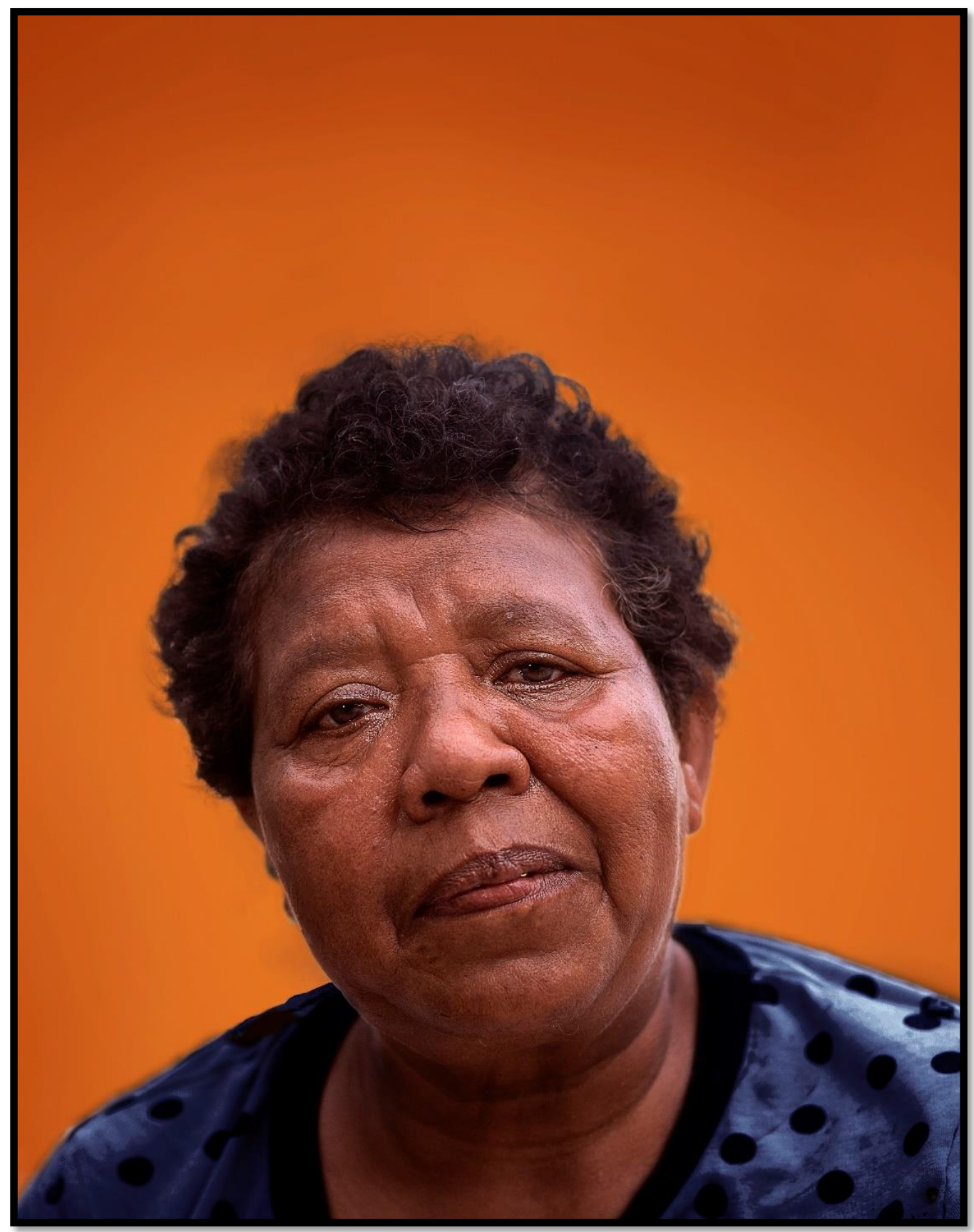

Figure 6 - Morena woman 


\section{Chapter 3: Celebrating morenos? Discourses of Differentiation and Violence}

"Damos inicio al encuentro de colectivos de nuestra zona escolar con la finalidad de llevar a cabo el mensaje de la cultura afro mexicana y que los alumnos conozcan su descendencia, gastronomía, raíces, cultura, costumbre y organización política. ;Vamos a dar inicio! (We officially start the encounter of school collectives of our school zone, intending to amplify the message of the Afro-Mexican culture so that our students become aware of their descent, gastronomy, roots, culture, customs, and political organizing. We are about to start!)"

The Tutuepec school zone chose October $25^{\text {th }}, 2019$, as a day of celebration. The sun gleamed in the sky, and under the roof of a basketball court in the community of $L a$ Consentida, a crowd gathered. After a brief message from the director of the host school, the national anthem started playing. Everyone stood up, and out of a crowded corner, six students began to march in unison to the rhythm of the anthem. The six pre-teens wore white and blue uniforms; the girls had picked their hair into high buns and sported high socks and skirts that fell below their knees. The boys bore blue striped vests, black pants, and ties. A girl walked in the middle of the group and carried in her arms a folded Mexican flag adorned by its green, white, and red colors, which gleamed as it reflected the light of the sun to the public. Surrounding the children, the spectators stood with their left arms to their chest, and their right arm stretched outwards with their palms flat to the floor. The event started with the traditional national customs - saluting the flag and listening to the national anthem. 
Exhibitions highlighting the culture and ways of life of las personas de la raza negra, people of the Black race, as a spokesperson for the event would later enunciate, packed the court. The exhibitions, presented by regional teachers, contained images, items, and written work to inform and represent the Tututepec school district's Black communities. The event depicted various Afro communities of the area, such as Charco Redondo and San Miguel del Progreso, and all of them had their exhibitions in place. The teachers representing the community of Chacahua put up a palapa, a three-sided enclosure, opened to the front, made with dried palm leaves and bamboo. Adorning the palapa they placed trasmayos, "gill nets" that hung from the supporting bamboo branches, and a colorful hammock stretched from one side to the other. Glued to the ceiling, cardboard cutouts in the shape of fish had common local words written on them like chocante, chirundo, and chimeco. On the floor, two unopened bottles of beer, Corona and Victoria, laid on top of a tree bark right next to a box labeled Grupo Modelo Mexico, a national beer brewery. Chacahua's neighboring town, El Azufre, had its exhibition in proximity. El Azufre had a big greenish trasmayo net with pictures hanging from its ropes enclosing its space. The presenters had set out tables with homemade figurines of turtles and boats on both sides of the net, and on the floor, presenters placed gill nets filled with soda cans and broken coconuts shells.

I watched the proceeding from within the crowd. The anthem, salutations to the flag, and the marching seemed like a ritual, a spectacle of national pride and assertiveness. Not too distant from me, a couple of men I recognized as mestizo teachers talked amongst themselves; "Es que se están desquitando we (they are retaliating, man)" one of them said jokingly. "Ya sabes, cómo los tenían de esclavos (you know, since they had them for 
slaves)." As I overheard their comments, I wondered how the event would unfold and what their conversation signified. In this space, different sectors and narratives aligned to highlight the continuum of inclusion and exclusion commonplace in the lived experience of morenos in this region of the coast of Oaxaca. The fact that teachers located "the African presence" in discrete coastal communities, combined with how teachers displayed alcohol cans and brewery boxes as representative of the experience of morenos in the exhibitions, and the comments I had briefly heard already said plenty about racial tensions.

Representation matters - especially in an event meant to highlight Afro-Mexican presence and incite pride in their communities. In hindsight, the use of beer in the exhibition of Chacahua alluded to potentially negative attributes found in moreno communities. Likewise, linking morenos to Africa, to slavery, and to a conscious resentment hints at the types of discourses prevalent in regional settings.

Throughout this chapter, I will explore the mechanism through which racial technologies racialize the people of African descent of the coast of Oaxaca, paying special attention to how different contrasting discourses of Blackness and "moreno" take place. To this end, I divide the chapter into three parts. First, by contrasting the Tututepec event with data from my field site, I discuss the regional and local narratives surrounding morenos. Second, I explore how regional narratives draw from broader national silences regarding Afrodescendants. In combining these elements, I aim to provide a picture of how the national imaginary excludes Afro-descendants, pitting the discourse of "morenos" against broader 
ideas of Blackness. Third, I explore how morenos themselves perpetuate these discourses by distancing themselves from Blackness and the harmful rhetoric employed against them.

\section{Event Backdrop}

Months before the Tututepec event, intending to foster pride and acknowledgment of morenos in the region, teachers from the Tututepec school district gathered and discussed how to research and present information regarding the Afro communities to their students and the general population. I attended a couple of these meetings to provide support and to learn how teachers perceived and talked about race. The Tututepec municipality, with its seat in San Pedro the Tututepec, encompasses the geographical terrain that goes from the Rio Verde River to the town of Rio Grande, stretching from the coastal towns to the high lands. Through various meetings, the teachers located specific "moreno" communities and formed groups of roughly fifteen teachers per group to research each community's customs, traditions, and demography.

These teachers did not conform a monolithic whole; although, for the most part, they selfidentified as mestizo and indigenous, they came from various socio-economic positions and regions. According to my observations, they generally embodied and enjoyed more socio-economic advantages than locals. Also, I find it important to note how none of the teachers conducting fieldwork in El Azufre described or labeled themselves as morenos or Afro-descendants. 


\section{Theoretical Framework}

As discussed in the introduction, I use the term moreno throughout this essay in two ways: First, I use it to describe people who self-categorize as moreno and possess African phenotypes. And second, I use it to indicate a particular discursive figure imbued with historically and locally produced meanings in tension with national narratives. Throughout this chapter, I explore the different racializing discourses of "moreno" and Blackness moreno as a racialization process that is localized and contextual to the experience of people of African descent in Costa Chica and Blackness as general discourse that relates to Africa, slavery, foreignness, and national ills.

To think about local, regional, and national subject positionalities, I first combine two definitions of identification in general and race in specific. I conceptualize racial forms of identification as a decentered interplay of meanings, values, and symbols pervaded by socio-political conflicts between the subject (signified by body characteristics) and others (Hall 1992, 277; Winant 2004, 155). I frame racial identities as socio-historical dialectical processes imbued with signification and relational to the mediation of different societal sectors. I also employ the term 'racialization' to refer to the processes in which meaning becomes embedded in the bodies of Afro-Mexicans (Murji \& Solomos 2005, 150). Visualizing morenos' plight as a historically racialized community allows for a better understanding of how morenos experience racial violence while simultaneously perpetuating it. 
To speak of the processes of racialization and its consequences, I utilize two main theories. First, I employ Biolsi's framework of racial technologies to explore the discourse around morenos and their dialectical relationship with their region. This process constructs morenos as a specific racialized group. Biolsi's descriptions of the mechanisms of stating, mixing, spacing, and classifying provide a framework to analyze the locally produced narratives and visualize the development of a moreno subject position (Biolsi 2004). For example, through these racial technologies, I can conceptualize how narratives that label morenos as lazy and overly sexual use the mechanism of stating, which defines the positionality of the person making the statement and those on its receiving end. Similarly, through the technology of spacing, I can address how discourse that locate morenos to coastal communities serves to exclude them from the general population and ideas of national belonging.

I address the "appearance of cohesion" that characterizes racializing discourses by drawing from Bonilla-Silva's theorizing of racial orders (Bonilla-Silva 1997). His theory provides insight into how racialized subjects and their counterparts inhabit a racialized society. For example, Bonilla discusses how "racial phenomena are regarded as normal" (Bonilla-Silva 1997, 472) and how locals describe "racially motivated behavior ... as rational - based on the races' different interest" (Bonilla-Silva 1997, 473). Bonilla's theory helps frame the flexibility and transformation of the discourse surrounding Blackness in national, regional, and local settings by establishing the parameters in which they work and how residents come to perceive them as commonplace ideas. 
To contrast the locally produced narratives of discrimination with the national silences surrounding Afro-Mexican communities, I draw from Hall's ideas on the national culture's discursive strategies (1992). His line of inquiry emphasizes the "narrative of the nation as it is told and retold in national histories, literature, the media, and popular culture" (Hall 1992, 292). I use these concepts while mindful of the ideology of mestizaje, the national discourse of mixture between Indigenous and Spaniards, as a local and regional narrative that shapes the racial and ethnic conceptualization of the residents.

Narratives of Race

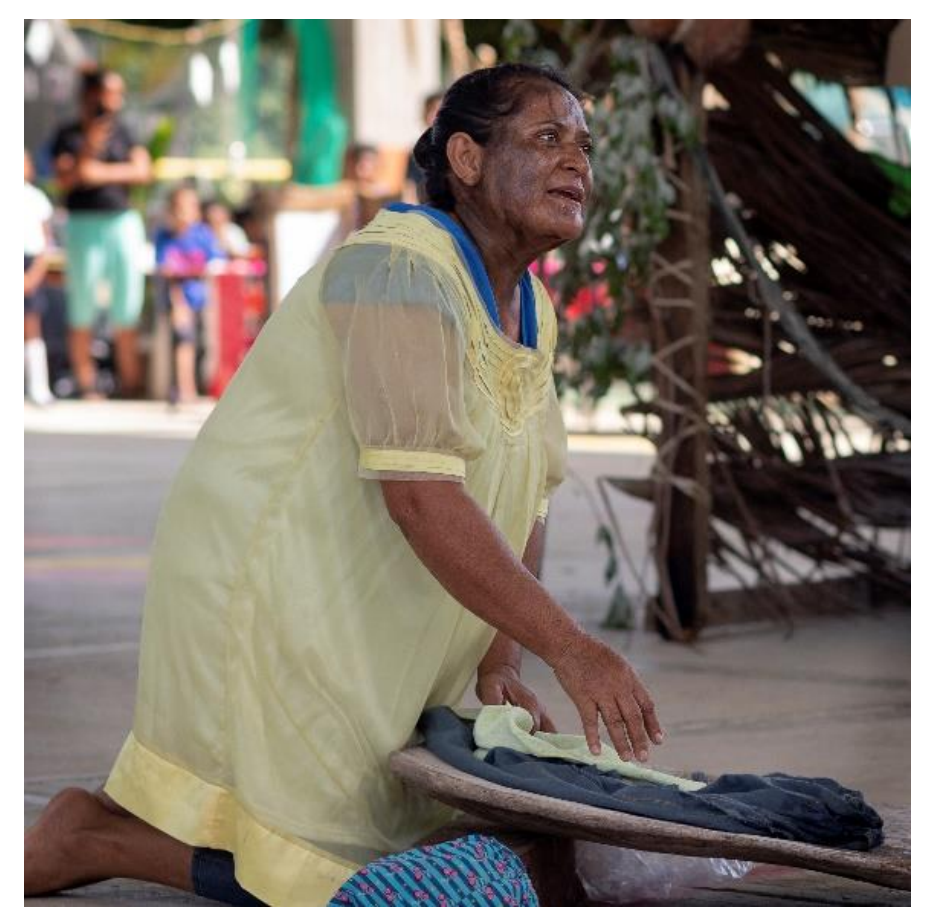

Figure 7 - Mestiza wearing Black face

"La representación que están apunto de ver de ninguna manera intenta burlarse de las personas de herencia afrodescendiente (the representation you are about to witness is in no way trying to mock Afro-descendant people)." A spoke person stood in the middle of 
the court and uttered this disclaimer marking the beginning of group presentations. In a short instance, the spoke person emphasized the educational nature of the presentation about to take place and denounced any characterization of wrongdoing.

Accompanying the exhibits, the teachers set up various productions to speak about their assigned community's customs and traditions. The teachers assigned the community of Puerto $^{2}$ performed first, and upon their time to present, multiple teachers took center stage in the basketball court. As they set their props on the floor and took their respective places, one of the group representatives grabbed onto the microphone to give a short presentation. When he finished the disclosure, the teachers began their production of life in Afro communities, starting from African's arrival on Oaxaca's shores.

Nine members in total conformed the group, all wearing colorful clothing. Five men wore pastel hats, bright-colored shirts, mostly unbuttoned, dark blue and black jeans, and sandals. Four women wearing dresses and skirts, all barefooted, took positions kneeling on the ground. In hindsight, their presentation outwardly referenced the physical work the teachers, who self- identify as indigenous and mestizo, believe prevalent in their assigned moreno community. In their representation of the activities found in Puerto, men carried trasmayos, gill nets, and machetes, while women kneeled on the ground doing housework - cooking and washing clothing. They also presented more insidious representations. In their portrayal of morenos, they distorted women's bodies - some of the women had balloons stuffed in their clothing to appear more voluptuous, while others wore messed up

\footnotetext{
${ }^{2}$ The community's name has been changed to protect privacy
} 
wigs that gave the appearance of curly hair. Perhaps more interesting is how most, if not all the presenters, had painted their faces with charcoal, as shown in figure seven, regardless of their skin tonality.

Their story began with a sunken ship arriving at the Costa Chica region, with Africans deciding to stay and acclimating to the new land's challenges. Through their voices and props, the presenters recreated the sounds of a thunderstorm and comedically represented the newcomers as incapable and ill-equipped to handle and shield themselves from the climate. Once the storm had passed, a seductive woman with a disproportionate body entered the scene, seducing various men to procreate with her. By the end of the act, the woman had children, the father had disappeared, and three men, representing the children of their broken union, had entered the stage. They stuttered incessantly, incapable of pronouncing their names. "Yo me llamo Rafiupuss (My name is Rafiupuss)," one of them said as if trying to pronounce the name Rafael. The presentation lasted fifteen minutes - a short time if taking into consideration the reaction of the public. As the presentation went on, most people in attendance, a combination of mestizos and morenos, clapped and laughed.

The presentation of the Puerto school allows for various levels of analysis. First, it provides a picture of the racial technology of stating in the regional and national narrative (Biolsi 2004, 402). These negrophobic statements serve to define, describe, and locate Black people. The theatrical presentation by the faculty of Puerto, which mirrors various accounts I have heard while conducting fieldwork, exposes Black people as lazy, overly sexual, full 
of vices, and mentally incompetent. In articulating people of African descent in this way, through mechanisms of difference, the speakers construct their ideas of morenos and themselves. But, they construct these ideas through decontextualized stereotypes and narratives. Inevitably, the characterizations of Blackness witnessed, with its emphasis on phenotype, mental ineptitude, and lack of character, reproduces a discourse with which morenos do not identify. This Black construct is visible as teachers accentuated Black phenotype. These accentuations serve to classify and give the illusion of "discrete, mutually exclusive, races" (Biolsi 2004, 409). As seen in figure seven, although of various skin tones, the teachers assigned the school of Puerto felt the need to darken their skin with charcoal, demonstrating how in the regional imaginary Black people have jet Black skin and have other distinct features that locate them, like curly hair.

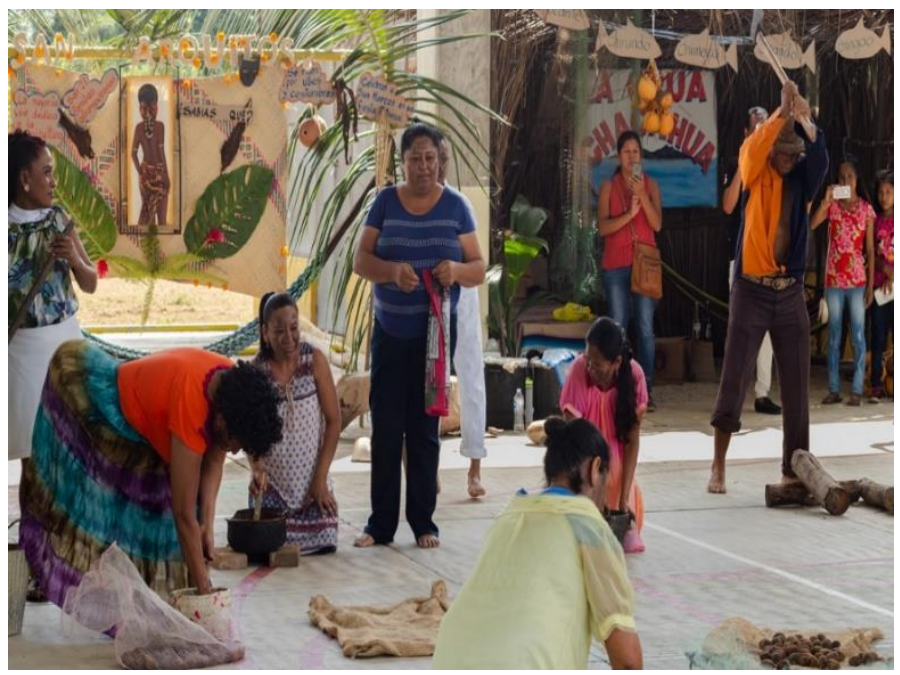

Figure 8 - Portrayal of morenos by mestizo regional teachers

Likewise, the presentation engendered racial classifications, as shown in figure eight. In the presentation, teachers portrayed women of African descent as dark, voluptuous, and 
with raggedy hair. The accentuation of breasts and buttocks in the performance categorized Black women's bodies while simultaneously mirroring and alluding to the oversexualization and lust commonly found in stereotypes. Racialized and gendered narratives aligned in this presentation as the teachers portrayed single motherhood as a Black occurrence and accentuated how they perceived Black women look.

Some of these characteristics mirror and reinforce each other to provide the appearance of a cohesive narrative. The cohesion of racialized markers rationalizes and normalizes racially motivated behavior (Bonilla-Silva 1997, 473). Like the case with morena women having voluptuous bodies, these characterizations reflect and circle back to other themes found in the racialized narrative, like morenos' over-sexualized character. Nevertheless, the fluency in these racial markers and forms of identification, more than highlighting any concrete evidence to discreet 'races' in the region, provides a contour of the boundaries of the mestizaje ideology. As Biolsi states, the dominant discourse views miscegenation as a threat to socially established boundaries, which commonly represent the Mexican mestizo as a whitened $(2004,406)$. However, Black is a moving target in Mexico (Sue 2008). Because of this, the only 'real' Blacks who Mexicans can partially locate with some accuracy are those who have various African features and live or frequent historically Black defined spaces, hence the people of the Costa Chica - a statement that erases the heritage and composition of the Costa Chica resident as people of both African and indigenous ancestry. In this way, the racializing discourses tend to target and construct a general decontextualized Blackness. 
Similar to the discourse found in the presentation, interviews with mestizos and indigenous people of the Costa Chica region highlighted similar general ideas. During the presentation, I had a chance to speak with Luisa, a mestiza woman from the community of La Consentida. She verbalized various negative narratives and misconceptions found in the region concerning people of African descent.

- "But they're not from here, right" (referring to the morenos)

- "Black people are "mariguaneros"” (heavy marijuana users)

- "They're also aggressive."

- 'And they don't have a vision for the future. That's why they spend all their money on alcohol."

This short interview excerpt highlights the commonalities found in the discourse surrounding people of African descent found between non-morenos regional communities. Like the presentation, Luisa also talked about a not-too-distant origin story to explain the presence of morenos. Her comments on morenos' history, "But they're not from here, right," echoes the perspective many people have of morenos arriving in a crashed ship in a non-distant past. Likewise, Luisa also employs the racial technology of stating when she characterizes morenos as morally lacking by describing them as "aggressive, mariguaneros, and alcoholics." These characteristics might also be easily associated with general Mexican communities, but she chose to attribute negative characteristics to morenos. 
The statements and classifications by the Puerto school presentation and the interview excerpt rely on a combination of localized and broader characteristics and narratives. Black people's phenotype, for example, as jet black, fails to portray the diversity in skin tonality found within Afro-Mexican communities in Costa Chica while alluding to some general idea of Blackness. In contrast, their depiction of regional issues like alcoholism and single motherhood, found throughout various Mexican communities, as representative of morenos displaces issues the dominant culture wants to expel to a Black "other." Likewise, the presenters use various tropes to speak to localized characteristics, hence the use of machetes and gillnets.

In contrast to the discourse of "Blackness" employed by regional narratives, it is important to note how local racializing discourses tends to consider actual moreno experiences. The distinction serves to dichotomize the racialization processes mestizos and indigenous people use towards morenos, which draws from both localized and general ideas of race, and the discourse morenos employ to separate themselves from Blackness and fit into the national narrative.

\section{In the community}

The previous example presented a regional dichotomy of the narratives that enmesh the moreno experience. I want to take a quick moment to nuance these narratives and provide examples of how they translate to local experiences - how they transform to accommodate local situations and reformulate themselves in various ways depending on the context. 
As I spend time in El Azufre with the teachers and other community members who described themselves as indigenous and mestizo, I frequently heard certain remarks. "Tu sabes como son ellos (You know how they are)." "Estos morenos te chingan, no les puedes dar ni un tantito de cuerda (These morenos will fuck you over. You cannot give them a bit of leeway)." Locally, even in El Azufre, a community where most of its members have Afro phenotypic features, these narratives are commonplace. In contrast to regional narratives, local rhetoric speaks to morenos specifically and takes a different dimension that emphasizes their character. Hardly anyone in El Azufre would agree on the laziness of morenos when they know the amount of work that fishing and farming entail. Likewise, local mestizos and indigenous people could scarcely ascribe morena women solely to domestic work when local women involve themselves in fishing, collecting menjuas, a small shrimp found in the coastal waters, and organizing community events. Instead, mestizo and indigenous residents of El Azufre characterize the nature of morenos as untrustworthy and prone to wrongdoing.

These racial technologies are flexible and accommodate local conditions. For example, even troubles rising from religious differences have begun to mirror racialized discourses. In the last few years, prominent mestizo members of the community converted to Protestantism and became Pentecostals. The local discourse began to link Pentecostalism with piousness and restraint and Catholicism, the religion of the local morenos, with sexual depravity and alcoholism. Mestizo residents warned me about Catholic festivities, like the one I exemplified in the reflexive chapter, saying they considered the festivities surrounding the festival of the Virgin of Juquila idolatry; they also emphasized the vices 
and over-sexualization of the people doing the veneration. When I showed interest in participating in the festivities of Juquila, one of my collaborators commented; "Ellos están todos ahí teniendo sexo, viejos con niños y mujeres casadas con solteros (They're all there having sex with each other, old people with kids and married women with other men)." Morenos, then, became a mirror of those vices. Despite the narrative, the community holds various Catholic events, and mestizo and indigenous families participate in the proceedings.

Lastly, not all narratives and stereotypes have negative characterization, and locals do not mobilize all these images against morenos. For example, during my stay in the community, an indigenous man said of his morena wife and her people, "Son de una raza viva con energia (They're from a race full of life and energy)." His words characterized morenos positively but still categorized them as other.

In these ways, racialized societies reproduced the racial order throughout various local and regional levels. Although slightly different at each scale, the translating of these discourses presents the idea of a cohesive whole that follows the appearance of rational racial differences. In addition, through racial technologies like stating and classifying, mestizos and indigenous people separate morenos from local and regional narratives - marking their bodies in opposition to indigenous and mestizo classifications. Nevertheless, just like local narratives mirror, although imperfectly, regional ones, these regional racial technologies also mirror and reproduce broader national ideas that erase people of African descent and 
mark Blackness as foreign. National erasure provides the backdrop from which morenos disarticulate their Blackness.

Drawing From The Void

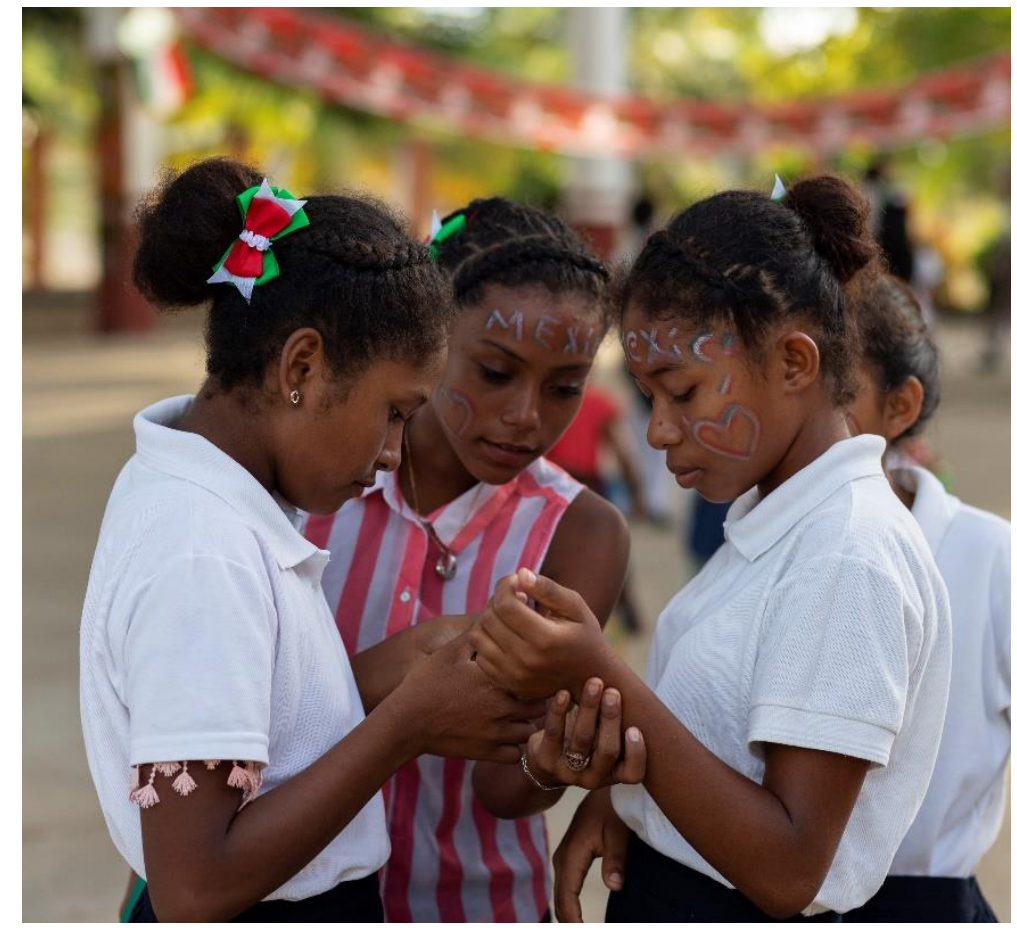

Figure 9 - Group of girls with Mexico written on their foreheads

"Nunca supe porque tu me dejaste,

si yo tanto te amaba (...)

será porque soy pobre y nada te ofrecía

pero vas a entender cuando andes con el, que yo si te quería"

I never knew why you left me

If I loved you so much

Maybe it's because I'm poor and I could not offer you much

But you'll understand when you're with him

That I did care for you

- La herencia del Chuy 
La herencia de Chuy played loudly throughout El Azufre. In the communal space of la agencia municipal, where residents hold most events, community members had set up speakers from which the music originated. The agencia consists of a roofed basketball court and, to its side, a small two-room structure used mainly for storage. Today, red, white, and green banners and medium-sized Mexican flags hung from columns and light polls decorating la agencia and the surrounding streets. The whole community buzzed with activity. Some people carried posters of national heroes, while others adorned their faces by writing "Mexico" across their forehead and cheeks, as in figure nine. In the streets, underneath the blazing sun, school children marched around the community wearing traditional outfits; the boys wore white shirts, white pants, and simple sombreros and clutched wooden rifles in their arms. In contrast, the girls wore traditional Mexican clothing, long skirts that covered their legs, and white shirts embroidered with colorful flowers. The girls wore their hair braided into pigtails. To the side of la agencia, in one of the colmados, store, older men sat, drinking, talking, and enjoying the festivities while women and some fathers stood on the streets watching the kids march through. The wind had settled, but the marching stirred up clouds of dust. Although the day felt hot and dry, las fiestas patria had everyone outside of their homes and taking a day off from work.

Azúfreños consider national and religious traditions significant, and they have embedded these traditions into everyday life. Thus, exploring how residents articulate different racial discourses locally necessitates a look into the place these activities have in the community. Regional forms of racialization draw from national narratives about "Black" people or the silences surrounding African descent people. The erasure of Blackness from the national 
imaginary gives way to dislocations and ruptures that have increased discrimination and systemic racism. These erasures have also produced a racialized moreno subjectivity that distances itself from Blackness. The active national erasure and distancing from Blackness juxtapositions morenos against the nation's broader ideas, creating a crisis of identity (Hall 1992). The following paragraphs explore this juxtaposition by discussing the Mexican nation's discursive strategies as it encounters people of African descent.

\section{Narrative of the nation}

In 1925, Mexican writer Jose Vasconcelos crystallized the idea of the Cosmic Race as a viable alternative for the nation-building project. Since then, mestizaje has come to symbolize and represent Mexican people - a body of miscegenated peoples that take on the best traits of their root cultures (Stavans 2011, 45). Historically, mestizaje has represented the amalgamation of indigenous people and Spanish conquistadores. Mestizaje represented the Mexican people, a concept that relegated indigeneity to the past and left out the African communities from the equation. Thus, within contemporary Mexican society, people of African descent do not exist, and the dominant culture perceives purely indigenous communities as backward. The modern erasure of morenos from Mexican society and the discourse of politicians demonstrates this pattern. Media production and politicians rarely portray and represent morenos. Unlike morenos, mestizos, and to a lesser degree indigenous people, figure prominently in telenovelas, and news stations. They also conform the majority of political figures. In contrast, upper-class whites or mestizos often occupy these positions. In 2005, former Mexican president Vicente Fox reference the 
mutual exclusivity between Black and Mexicans in the national discourse when he commented on how in the United States, Mexican did the jobs not even the Blacks want to do (Sue 2010, 273). In this way, the national discourse erases all African presence, historically and contemporary. Consequently, Afro-Mexican historical figures also undergo a process of blanqueamiento, whitening.

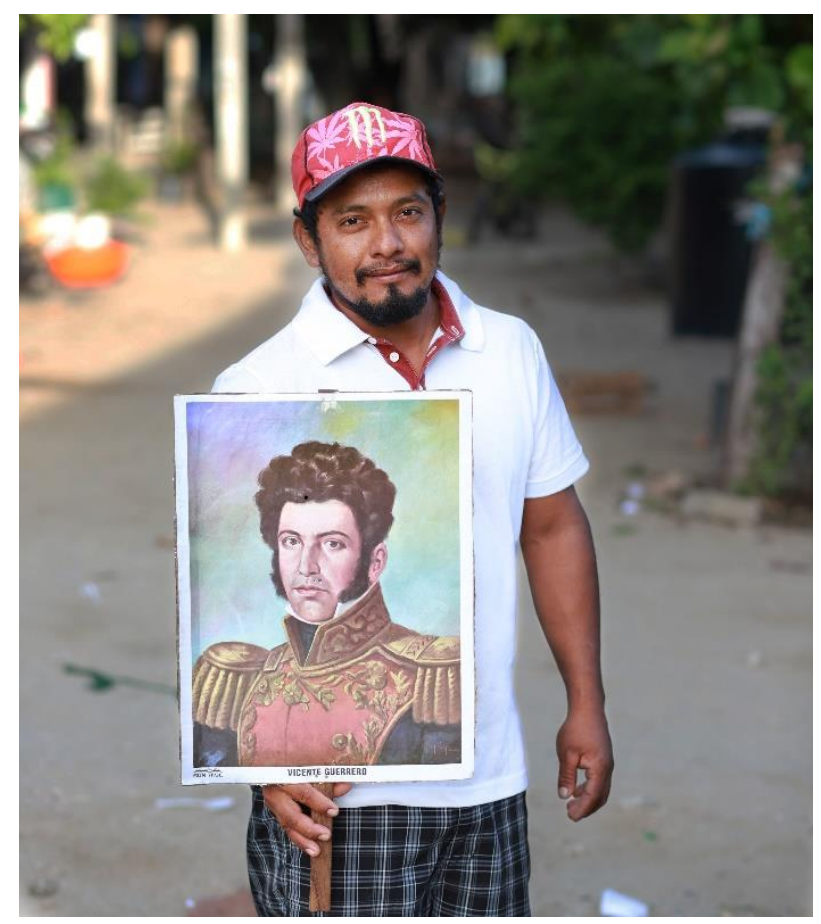

Figure 10 - A man from El Azufre holding a cartel of Vicente Guerrero

Figure nine shows an artistic rendition used in the community of El Azufre of Vicente Guerrero. An insurgent in the war against Spain in the 1800s, Vicente Guerreo fought and achieved its success. He briefly became president of the country in 1829 and signed into law the abolition of slavery. Historians contest Vicente Guerrero's heritage; many characterize him as mestizo while others see him as mulatto. Nevertheless, in paintings and 
other portrayals, renditions portray Vicente as having dark brown skin - unlike the very Europeanized version in the poster. Blanqueamiento, as a technique that distances Mexicans from Blackness, figures prominently in the national imaginary found in the community of El Azufre. Vicente Guerrero hardly represents a unique case. The Mexican discourse has also whitened other figures, such as Antonio Alvarez, a revolutionary who fought against Santa Anna's dictatorship in 1850, who was also of Afro-descent.

The lack of dark-skinned individuals with African features in the historical and contemporary Mexican imaginary aids the construction of Black people as foreign. It also expels people of African descent from the national imaginary. As Hall describes, "national identities ... are formed and transformed within an in relation to representation" (1992, 292). The lack of representation and perceived foreignness of people of African descent translates to local discourse on Blackness which becomes a tool in the racial technology of stating. In "Negras," a recently released documentary about life in Guerrero's Costa Chica region, a self-identifying Black Mexican woman asks a nearby pedestrian with dark skin and prominent African features if he considered himself Black. His response, "Yo soy moreno (I am a moreno)," to which she replied, "¿Moreno no negro? (moreno or Black?)" This interaction signals the clear distinction prevalent in the region about what these terms mean, one local and the other foreign.

My interviews with various residents from El Azufre also highlighted the violence produced by this erasure. In conversation with Julio, a local moreno, he stated:

- "When I leave the community, people ask me if I'm del Norte." 
- "When I tell them I'm Mexican, a lot of them don't believe me."

- " "In the north is the same; one time when talking to some gabachos (Americans) in a place full of Black people, they didn't want to believe I was Mexican.”

As a result of morenos' erasure from national discourse and imagery, morenos have come to be perceived as foreign in their own country by their neighbors. Many of the interviews I conducted throughout El Azufre and people of adjacent communities mirror these themes highlighting how questions of national belonging are a common experience for morenos in national and transnational settings.

\section{Emphasis on Origin}

Many stories of origin in the region attempt to account for the presence of people of African descent in Oaxaca and Guerrero. In El Azufre, residents have their version of the story. As Miguel told me in Chapter two, "Se cuenta que hace tiempo varo un barco que traía esclavos negros de Africa, en el 'Puerto Minizo', al sur de Chicometepec, en el Océano Pacifico (People say that some time ago a ship full of African slaves crashed in the port of Puerto Minizo south of Chicometepec in the Pacific Ocean)."

Common place origin stories such as this one serve to position morenos inside the regional landscape. Nevertheless, these stories situate morenos as newcomers or descendants of newcomers into the nation, legitimizing their erasure from the national narrative, validating their perceived lack of historical contribution, and placing them as foreign. If the Mexican national narrative represented the country's African presence as a historical occurrence that coincided with the Spanish conquistador's arrival, the national imagery would represent 
morenos as Mexican as los gueros del DF - European-looking Mexicans in the Federal District. The exclusion of morenos from the foundational myth of the country, which grounds the narrative of mestizo communities, serves to separate people of African descent (Hall 1992, 294). Nevertheless, like the theater witness by the communities of Tututepec, these origin stories drew from this historical inaccuracy. They placed the arrival of morenos as a recent phenomenon despite African presence in the country dating back to the $16^{\text {th }}$ century. Their perceived recent arrival identifies Afro-Mexicans as perpetually foreign. In doing so, the narrative invalidates the historical presence of people of African descent and the ties and histories that have defined the relations between indigenous people and Mexicans of African descent in the region.

\section{Individual Silences \& Perpetuating Narratives}

Throughout this essay, I have explored how harmful discourses regarding people of African descent permeate local, regional, and national narratives. I have also tried to give some examples of how these narratives transformed at each level in society. To explore how these discourses form a social structure that constrains the subject positionality of morenos, I address how morenos themselves perpetuate it.

In the presentation of El Azufre at the Tututepec school event, the teachers chose Sandra, Victor's wife, a dark skin morena from the community, to deliver a speech. Sandra has charisma. Nevertheless, through her speech, the regional teachers in charge of the presentation expressed many of their biases. Both spoke about how morenos tend to disengage from traditions and customs that do not involve partying and alcohol and directly 
compared morenos to indigenous people, highlighting the latter's positive characteristics and the former's backwardness. Consider the following section of the document Sandra read:

“Las personas morenas, se prestan a alejarse más de las tradiciones, se ha notado que le dan poca importancia. Mas no así las personas indígenas ... porque ellos si están más conscientes de sus tradiciones de las herencias de sus padres y abuelos $y$ del lugar de donde vienen. (The moreno people tend to distance themselves from traditions; it's been noticed that they give it very little importance. This is different from the indigenous people ... who are more conscious of their traditions, of the legacy of their fathers and grandfathers, and of the place where they come from)."

After Sandra had finished reading the document and taken her place outside of the stage, I stepped next to her side and asked what she thought. She said, "estaba chido (it was cool)."

Could Sandra, like many people in the audience, not perceive how the words she had read aloud disparaged herself and her community? As I will discuss further on in the thesis, morenos detach and distance themselves from Blackness. Nevertheless, the comments Sandra had uttered, more than relating to an abstract idea of Blackness, specifically targeted morenos. In one of my interviews about this topic with Rafael Lagunas, a local moreno who become one of my key collaborators, he mentioned, "Si uno no tiene raíz nada más existe. No tiene certeza de su identidad (If one doesn't have any roots, that person just exists without any grounding on their identity)." 
Nevertheless, Sandra's distance from her speech, the claps at the racist depiction of morenos in the past, and the local narratives by morenos themselves about the vices and problems their community members face speak to internalized mechanisms of distance that go unaddressed by morenos.

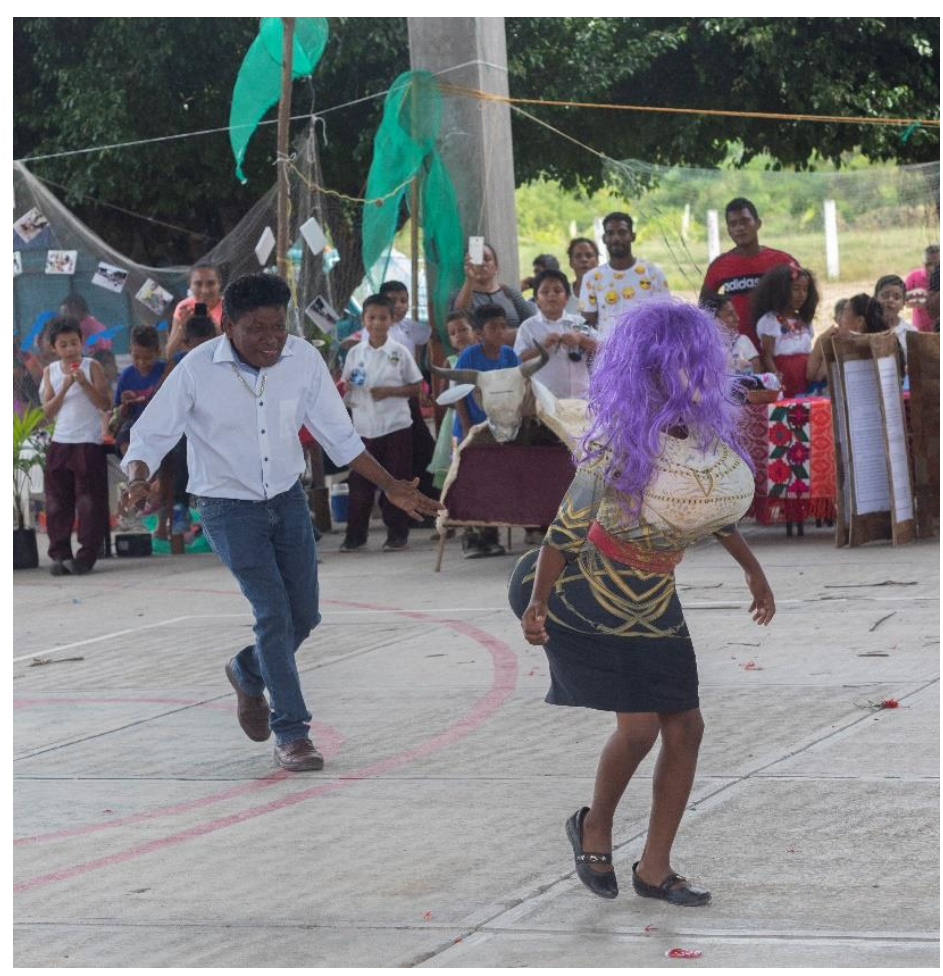

Figure 11 - La minga of Danza de los Diablos

Similarly, morenos themselves employ racialized and gendered discourses and forms of stereotyping that mirror and reproduce the commonly held tropes about Black people. The character of La Minga represents one of the most prominent examples. Present in a traditional dance called La danza de los Diablos, La Minga's character embodies a salacious woman with enormous breasts and buttocks, redeploying the voluptuous morena women's image as a comedic character. According to locals from El Azufre, the community 
adopted the dance with the arrival of Leopoldo Herrera from the community Santa Maria Chicometepec. The dance represents the invocation of an African deity, and performers structure the dance around a head devil who directs, controls, and punishes the other dancers, lesser devils, when they leave their place.

La Minga is the head devil's wife, and she dances around the lesser devils and flirts. In both appearance and trope, La Minga's character reinforces the ideas of a promiscuous Black woman - her overt sexuality manifesting itself physically through the shape of her body, as shown in figure ten.

At first sight, the trope found in La danza de los Diablos might appear to subvert racial stereotypes and mock the characterizations placed on people of African descent. However, a closer inspection reveals the context in which it takes place frames the discourse away from morenos and into Blackness. Morenos perform la danza de los diablos in cultural events. La danza functions as a representation of the past. Thus, through its performance, La danza de los Diablos relegates Blackness to distant heathen ancestors.

\section{Conclusion}

The Mexican national discourse has historically ostracized and erased Blackness from the national territory. Blackness then has come to represent numerous things, like a foreign idea and a placeholder for negative tropes Mexicans displace towards an "other." In the Costa Chica of Oaxaca and Guerrero, the discourse surrounding Blackness takes on a new dimension. Communities like El Azufre, where people have retained Afro phenotypes and which contemporary national narratives construed historically as the last refuge of a 
banishing Blackness, offer a space and bodies for an embodied discourse. "They can't be Mexican; they're too dark; their family has to be from somewhere else," the discourse suggests. "Of course their communities' reek of poverty, hunger, and lack of education; they are lazy, promiscuous, and lacking in foresight." In this way, the majority culture absolves itself of responsibility for the plight of the impoverished by blaming their condition on supposedly innate characteristics stemming from African heritage.

The dichotomizing of Blackness and Mexican nationality creates a crisis of identity for morenos who continuously get racialized as Black by dominant communities. This process of racialization utilizes what Biolsi describes as racial technologies to create discrete spaces for people of African descent, characterize them, solidify their subordinate status, and classify them outside of the parameters of mestizaje (Biolsi 2004, 413). This expulsion of people of African descent from the national discourse places morenos outside the boundaries of the ideology of mestizaje and demonstrates the holes in the historical account of the nation.

Throughout this essay, I have laid out the discourse surrounding Blackness in the region of Costa Chica and the prevalent processes of racialization that mark the Afro-descendant body as "other." This "othering" draws from different sources - local, regional, national, and general ideas about Black people. To demonstrate and contrast these different processes, I lay out a flow chart addressing the discourses around morenos in different settings. 


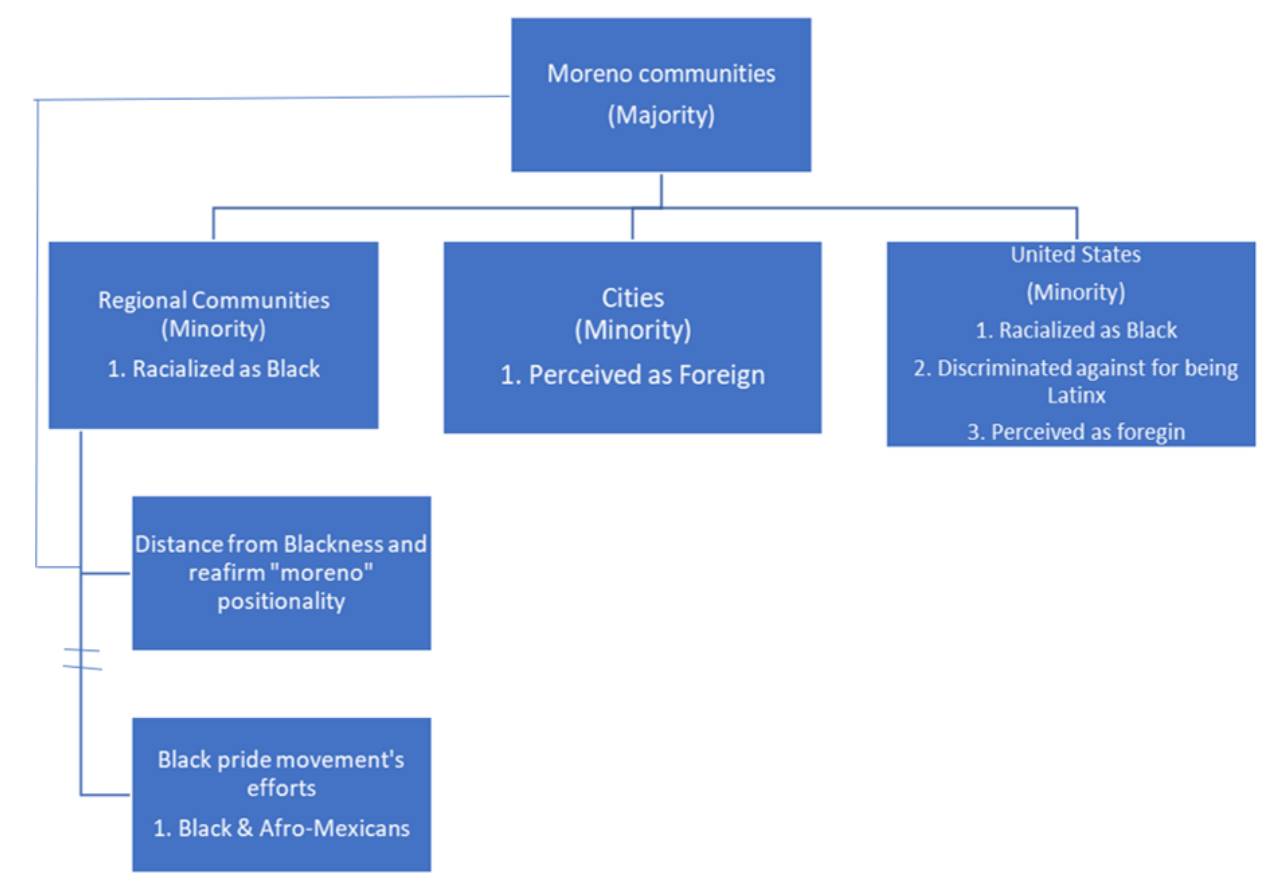

Figure 12 - Flow chart of discourses

The above flowchart represents the different spaces in which racializing discourses touch the lives of morenos - local, regional, national, and outside of the country. Although flexible, racial technologies that racialize people of African descent as a mutually exclusive group vary depending on the context where the discourse occurs. Within moreno communities, negative tropes are less salient. Because in their communities, morenos tend to be the majority, they easily subvert any negative rhetoric thrown at them by their mestizo and indigenous neighbors. Nevertheless, the lack of education concerning people of African descent in Mexico and the erasure of their contributions to the nation starts in these local settings. 
Regionally, the discourse surrounding Black people utilizes common general tropes, like poverty, addiction, lack of education, and single-parent households. Unlike in local settings, where residents contextualize negative tropes to speak to the general lives and attitudes of morenos by describing their profession, character, and bodies, regional disparaging discourse tends to address a generalized form of Blackness. Nevertheless, the multi-facet and multi-leveled discourses found at local and regional levels provide a cohesiveness that mirrors and legitimizes itself while giving the illusion of natural racial order (Bonilla-Silva 1997, 473). Because of this, comments regarding morenos by mestizos and indigenous people are hard to invalidate - they continuously transform themselves. Similarly, morenos also employ these techniques against fellow moreno communities. The comment "los negros estan alla (Black people are over there)" symbolizes the displacement of Blackness and a need, through the racial technology of spacing, to locate Blackness somewhere else, always in the next town over. Blackness remains a moving target (Sue 2010) that symbolizes characteristics to which morenos do not readily want to associate themselves with.

The Tututepec school district event provided a reference point for eliciting accounts of the regional narratives employed towards morenos and how those narratives are engendered and framed through socio-economic positions. In contrast, by looking at the origin story of moreno communities and the silences surrounding their bodies in the national narrative, it is possible to draw a direct line and see how these national and regional processes mirror and perpetuate each other. Nationally, people of African descent do not exist in Mexico this is evident by the rhetoric of legislators and the lack of representation in different 
mediums. Nevertheless, the prevalent discourse found in the community of El Azufre demonstrated how these ideas morphed and (re)formulate themselves locally based on setting and the conditions laid out before them.

Throughout this chapter, I have presented how racial technologies racialize people of African descent in Mexico. I have done this to demonstrate the social structure that constrains people of African descent. These narratives are one of the aspects that constitutes the discursive figure of "moreno." After laying out these notions, a straightforward question emerges. How do people of African descent navigate the discourse surrounding Blackness? 


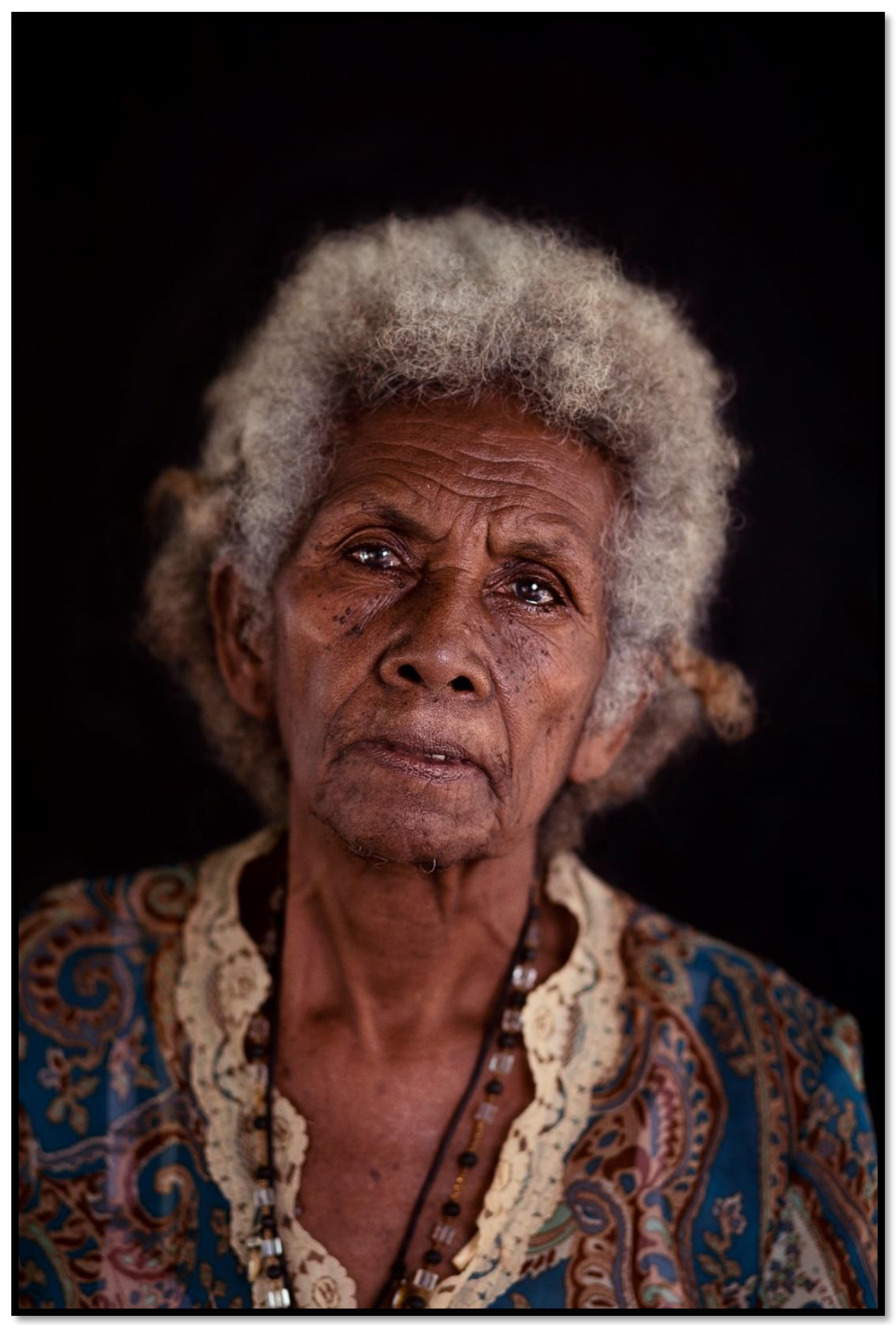

Figure 13 - Morena woman 


\section{Chapter 4: (Re)Configuring mestizaje: Moreno subjectivity and Black consciousness}

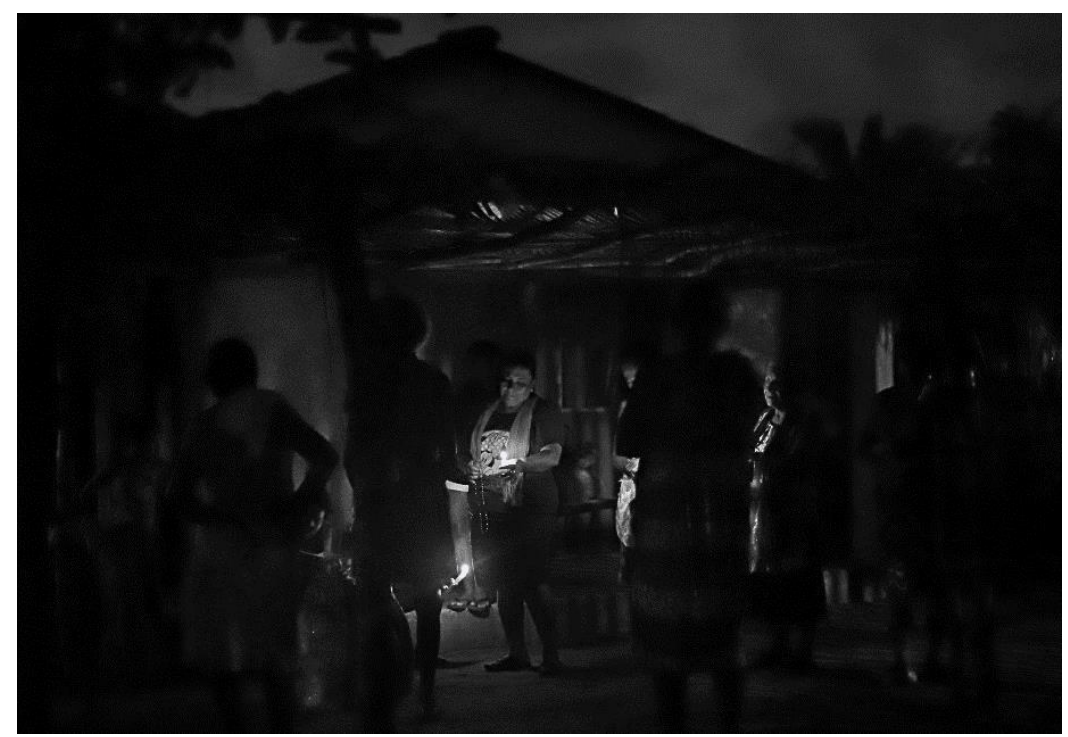

Figure 14 - People participating in "La entrega de la caja"

"Si por el mundo los hombres van, no niegues nunca tu mano al que contigo va, ven con nosotros al caminar, santa María ven" (If throughout the world men go, do not deny the hand of who accompanies you, come with us to walk, oh holy Mary come) - J.A. Espinoza

A group sang Espinoza's song in the pitch blackness of the night. Various women held candles as they walked, and in the center of the group, two women helped each other carry a wooden box - each of them holding on to one side. In the skies, residents could hear and see fireworks exploding. Doña Gabriela, a mestiza woman who had moved to El Azufre from neighboring Puerto, led the group through lyrics and prayers. The community residents, primarily women and their children, marched in unison, matching Gabriela's pitch in song and repeating the prayers. On this night, through the activities of walking, carrying candles and the box, the community participated in "la entrega de la caja (the 
delivery of the box)," which marked a symbolic commitment between the community and the person who receives the box, El mayordomo, the butler. By accepting the item, the community's new Mayordomo pledged to host and provide the resources to hold the festivities of La Virgen de Juquila in the upcoming year. When the procession arrived at its final destination, a small partially cemented house at the edge of the Rio Verde river, everybody stood and started to pray. "Ave Maria Purisima, libranos de nuestros pecados. Amen (Oh, pure, holy mother, release us from our sins. Amen)." Doña Gabriela repeated this phrase as she counted the beads of the rosary she held in her hand. Kids played at the peripheries, and a few people converse in the house entrance, but, for the most part, everyone attending stood quietly or recited the rosary. When Doña Gabriela's praying culminated, the new mayordomo's family walked over to the kitchen and served pozole costeño to everyone. With food in their hands, people began to talk. "Yo eso lo vi malo. El se paró ahí a decir que cosas de la virgencita de Guadalupe (I saw that as a bad thing. He stood there saying all types of things about the Virgin of Guadalupe)," said one of the women, referring to an event held a few days before by the Pentecostal church. "Algunas de ustedes estaban allá (some of you participated in the event), " interrupted Doña Gabriela with a quiet but firm voice. " $Y$ a diosito no le gusta eso (and God doesn't like that)." " $O$ estamos allá o estamos acá (Either we're here, or we're there)," she continued letting the people gathered know that they belonged either in the Catholic or Pentecostal church. But, according to her, God did not like indecisive people who dwelled in both religious contexts.

The phrase "O estamos alla o estamos acá (Either we're here, or we're there)" resonated with me as I tried to untangle what African descent represented on the Coast of Oaxaca. In 
a way, morenos inhabit an in-between zone characterized by the struggle of two forces: the first, the fervent Mexican nationalism morenos pride themselves in, and the second, the racialization and exclusion most experience throughout their lifetime. Prominent Black scholars such as W.E.B. Dubois have talked about a duality to the Black experience - a duality that contrasts Blackness against national ideas of who and what it means to be an American. In Mexico, the veil separating these two denominations is harder to peek through. People of African descent's assimilation and embrace of the Mexican nation clouds the duality of these seemingly contradictory forces.

Research that unquestionably categorizes morenos as Black leave unaddressed how AfroMexicans have historically navigated the Mexican national discourse and the dynamics produced by the duality between Mexican and Black. For Afro-descendants, "moreno" encompasses a set of lived experiences and ideas that reformulate mestizaje and Blackness and places them within the national narrative. To demonstrate this, I briefly track the historical narratives that have racialized the body of people of African descent through the racial technology of stating (Biolsi 2004, 402). I then explore how morenos reconfigure these narratives to fit into regional and national imageries. And lastly, after presenting how the Mexican discourse construed Blackness in the past and the contemporary racial articulations of morenos, I incorporate how the "Black movement" that has slowly taken place since the 1990s represents a transformation from how processes of racialization have historically taken place in the region. 


\section{Theoretical Framework}

The national ideology of mestizaje excludes people of African descent. Nevertheless, as it functions in everyday life, mestizaje serves as a space where (re)articulations of multiple traditions and practices can occur. In El Azufre, for example, various people of different descent co-reside with one another, intermarrying, sharing their resources, and participating in communal traditions. In this way, a description of morenos 'live experience and its implications on their subject positionality makes the separation of mestizaje's ideology from its lived process essential. To separate these notions, I turn to the idea of mestizaje as a lived process (Wade 2005). Wade's theorizing of lived experience nuances the spaces occupied by various groups by demonstrating how in any given space discourses of inclusion and exclusion can take place. In chapter two, I described these discourses of differences, but moreno communities also inhabit spaces of sameness.

By understanding how lived mestizaje functions, I explore morenos' positionality. I look at how morenos transform mestizaje as a lived experience and project it onto the national narrative. Morenos employ a series of mechanisms to reinsert themselves into the nation. In the community of El Azufre, people of African descent use their mixed ancestry, whether indigenous, mestizos, or Spanish, to claim a localized form of mestizaje. They also (de)construct notions of discreet Black spaces by utilizing cultural traditions and tools that incorporate various aspects of different Mexican communities. In this way, by using their own type of racial technologies, morenos reclassify, remix, and respace themselves (Biolsi 2004). They subvert and transform the narrative that excludes them. To explore this process, I turn the concept of racial technologies in its head and use it to speak on how 
through stating, mixing, classifying, and spacing morenos racialize themselves to fix into the nation.

Inevitably, this process of (re)insertion leads to a separation from Blackness prevalent in various Latin American countries. This distance takes many forms, from emphasizing European or indigenous heritage to erasing slavery and the connection, through descent, to Africa. To explore these situations, I used Puerto Rican researcher Isar Godreau's distance strategies, which speak to how, through silencing, trivialization, and simplification a separation from Africa and, consequently, Blackness occurs (Godreau 2008). Omissions and critical silences, like the erasure of people of African descent from the history books, provide a space from which to categorize Black people as inconsequential and even nonexistent in contemporary Mexico.

Lastly, my exploration of these processes sheds light on the rupture that has taken place between people of African descent and their history, heritage, and acceptance. (Dis)continuities position morenos as one of the many formulations of the Black diaspora throughout the Americas. Unlike various diasporas, morenos do not want to return to Africa. Nevertheless, as Hall mentions, "It was not literal Africa that people wanted to return to, it was the language, the symbolic language for describing what suffering was like" $(1995,13)$. In the Costa Chica context, this language takes the form of a Black pride movement. Contemporarily, morenos increasingly rearticulate a new positionality - that of Blackness. Through it, morenos fight the historical oppression the have experience - an 
oppression grounded in their erasure from Mexican nationhood and symbolic violence. Because of this, I frame my discussion of this return through a diasporic lens.

\section{Historical Narratives of Racialization}

To present how morenos navigate the duality of Blackness and Mexican belonging, the following paragraphs explore the ideas and characteristics that have historically signified African descent in Mexico. I use these descriptions to present the historical symbolic structure that has defined the discourse morenos must navigate to incorporate themselves into the nation. This structure paints a picture of what Blackness represented in the past, allowing me to discuss what it means contemporarily and visualize what it could represent in the future.

The Mexican national discourse has subjected people of African descent to symbolic violence to dehumanize and delineate the boundaries of their otherness, as seen in the presentations of Tututepec. Historically, in the $16^{\text {th }}$ and $17^{\text {th }}$ centuries, adjectives like vile, traitorous, and addicts described the character of African slaves (Aguirre-Beltrán 1972, 186). Stereotypes and other forms of discursive statements served to state what a Black person represented and, at the time, delineate discrete spaces for indigenous people, Blacks, and Spaniards (Biolsi 2004, 402). Adjectives, like the ones mentioned, followed African descendants as slaves increasingly miscegenated with Spaniards and Indigenous people. During the colonial period, people perceived mulattoes, the mixture of African and Spanish, and pardos, intermixing of African and Indigenous, possessed the worst qualities

of their progenitors (Aguirre-Beltrán 1972). In the early centuries of New Spain, Spain 
needed a discourse that explained the oppressive treatment of African slaves, and from that need, descriptions like heathens and savages arose (Wynter 2003). However, by the mid1700s, as miscegenation between Africans and indigenous or Spaniards took place, the discourse increasingly attacked mulattoes and pardos, who would take the mother's free status, placing them beneath Blacks (Valdes 1944, 179). As Aguirre-Beltrán points out, these narratives followed Black Mexicans until the end of the colonial period and the discontinuation of the caste system. Up to this point, Mexicans of African descent figured prominently in the national discourse of New Spain. As a violent instrument of colonial oppression, the caste system necessitated the clear delineation of ancestry and the acknowledgment of African heritage. In addition, as miscegenation increased, people of African descent progressively passed as originating from other castes (Valdes1944, 191). Historically, people of African descent's distance from Blackness functioned as a tool in the quest for freedom and acceptance.

With the abolition of slavery in 1829 , the euphemism of moreno started circulating. The use of the word moreno began a shift in perspective on who people categorized as Black. By 1836, various sources give credence to the "disappearance of Afro-Mexicans" and located the few "surviving Black communities" in discrete remote areas in the Pacific and Atlantic coasts (Vinson \& Vaughn 2005, 37). At this juncture, people of African descent changed from subjects of the colonial rule to a group that no longer existed and whose presence the national discourse located discretely and solely within specific spaces. The discourse surrounding the racial technology of spacing materialized, and people of African descent become separate and locatable to the Pacific and the Atlantic coasts. 
At the beginning of the $20^{\text {th }}$ century, when Jose Vasconcelos published his influential book on the Cosmic Race, the disappearance of Blacks in Mexico had almost solidified in the national discourse. Vasconcelos argued how Mexicans had inherited some of their worst attributes from Africans, like disease and sensuality, but relegated this contribution to something of the past (Vinson \& Vaughn 2005, 15). With the centering of the mestizo subject at the core of the national discourse, the already "disappearing" person of African descent no longer conform or attribute any aspect of the nation. The discourse surrounding people of African descent in Mexico transformed into "There are no Blacks in Mexico."

These occurrences highlight two facts: first, the hostile rhetoric historically defining people of African descent, and second, the disappearance of Black people from the national imaginary - Black people, if not entirely erased, are always in the process of extinguishing through multiple racial technologies. As a mechanism of resistance, people of African descent, or at least those who physically could, circumvented these narratives and their repercussions by passing as someone from another caste (Aguirre-Beltrán 1972, 271). Thus, historically, Afro-Mexicans have distanced themselves from Blackness to escape the circumstances and rhetoric surrounding them. This erasure of people of African descent (resulting from the national narrative and the mechanisms of resistance of Afro-Mexicans) and the hostile rhetoric placed on their bodies open a space from which to begin exploring how morenos contemporarily (re)configure the spaces and the narratives that exclude them. 


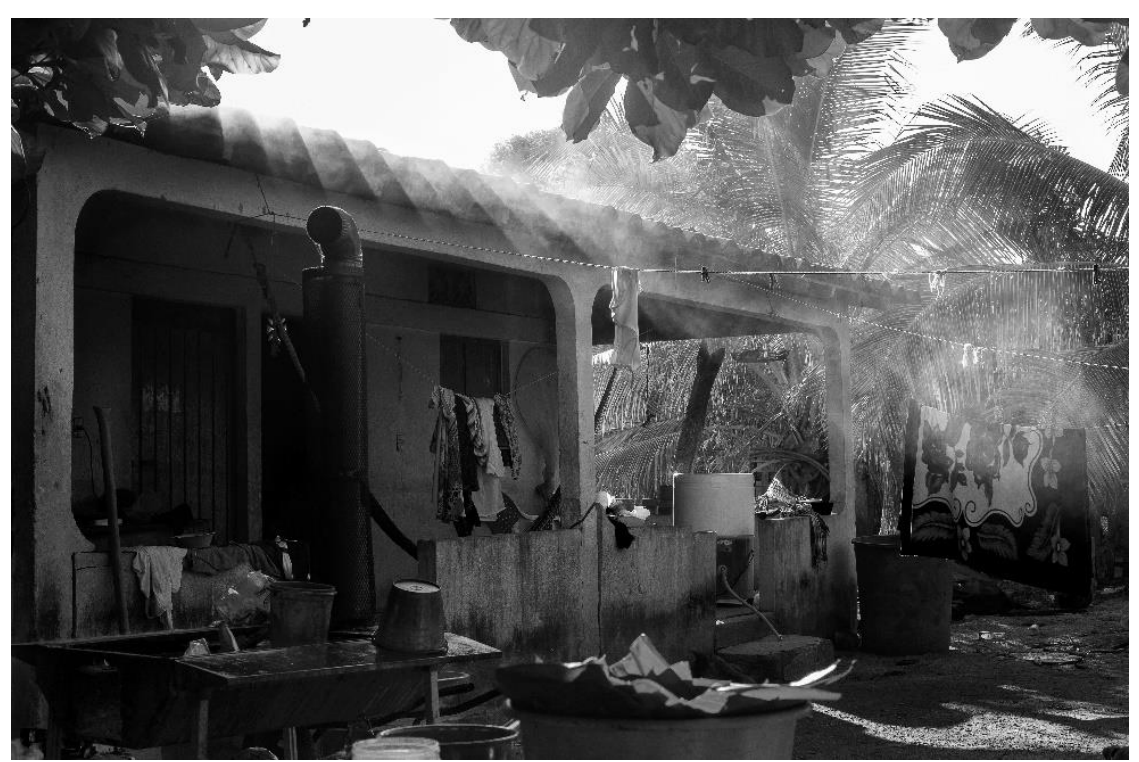

Figure 15 - Home of a moreno family

"Lo primerito que haces (the first thing you do)" is cook the onions, garlic, oregano, and the different chiles on a skillet. Cooking them beforehand makes it easier to take the seeds out of the chiles later. If you do not do this, your fingers will bother you when you get the seeds out." Carolina mentioned as she began cooking and showing me her recipe for pozole costeño. The pozole is a traditional Mexican stew dating back to the Aztecs. Numerous variations exist, but el pozole costeño with its red hue and the use of local condiments and chiles originates in Oaxaca and Guerrero's coastal communities. Carolina's mom had taught her how to make it, and by what she had told me, her mom had learned the recipe from her mom. Today she took the time to teach me. As she directed me to prepare the pots to start boiling the chicken, she grabbed the hot chiles from the skillet and started pressing her thumb against them to take their seeds out. Carolina was a seasoned cook; the hot peppers 
hardly bothered her. She finished taking the seeds out, grabbed the molcajete, an indigenous cooking tool, and started to grind the chile to make the sauce. "Deja el pollo hervir de quince a veinticinco minutos (Let the chicken boil from fifteen to twenty minutes)," she directed me as she kept grinding the chiles. I looked at her, surprised by the indigenous tool she used; her molcajete reminded me of a Pilon, a cooking tool used in the past by the indigenous people of the Caribbean. "Esto es un molcajete (This is a molcajete)" she said casually. "Lo necesito en donde sea que voy (I need it wherever I go)." "Esto y el metate (This and the metate)" as she pointed to another instrument at a nearby table. "I need that for the tortillas."

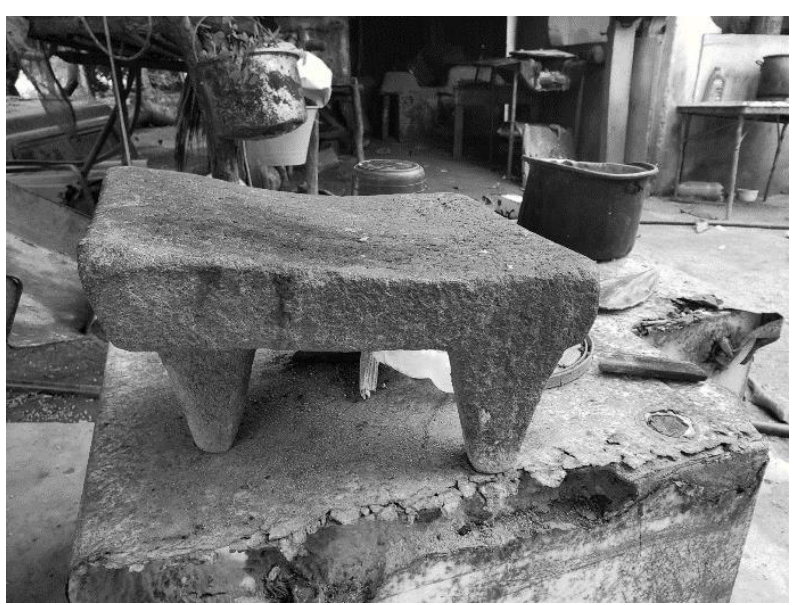

Figure 16 - Metate used to make corn tortillas

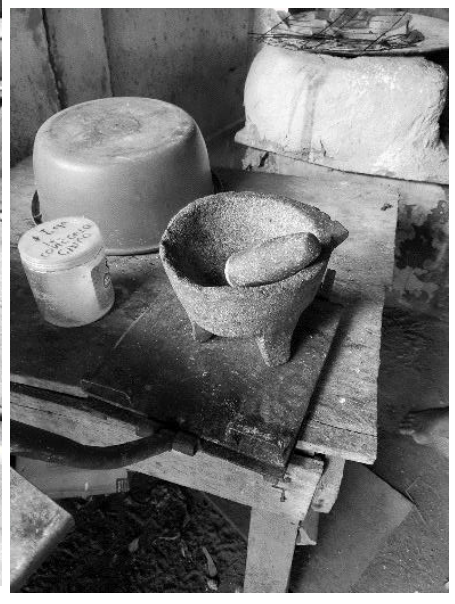

Figure 17 - Molcajete used to make sauce

There, underneath the shade of the house, Carolina spent her day cooking. In a way, like la entrega de la caja, cuisine exemplifies how morenos rearticulate mestizaje and ground themselves in an experience that incorporates indigeneity, mestizo, and local traditional knowledge passed down generationally. In this way, racial technologies like spacing and 
classifying, which give the superficial appearance of difference between morenos, indigenous, and mestizos, are exposed as partial as among these differences various instances of sameness occur. Thus, morenos' everyday experience, like Carolina's cooking, shakes the classifications that separate morenos, indigenous, and mestizos in discrete groups - highlighting how group miscegenation functions on a day-to-day basis.

In the context of El Azufre, morenos frame "lived mestizaje" by their experiences and yearnings. It opens a space in which to reconfigure and inhabit broader national ideals locally. The night of la entrega de la caja and the cooking of pozole costeño represents an instance of lived experience in which morenos construe and inhabit a space in which a symbolic reconfiguration of mestizaje flourishes. La entrega de la caja represents a Catholic tradition, led by a mestiza woman, constructed because of the sighting of a dark skin virgin by morena women in the community of El Azufre. Similarly, el pozole costeño is a historically Aztec dish, reconfigured through time to incorporate different ingredients. In the case of El Azufre, morenos prepare it using local herbs and chiles and generationally transmitted knowledge. El Azufre residents' lived experience breaks away from the racial technology of spacing in which the national discourse construes moreno, indigenous, and mestizo communities as separate (Biolsi 2004, 413). Morenos also reference this lived experience to (re)deploy racial technologies that seek to place them outside mestizaje.

Historical processes have stripped Afro-Mexicans of the ethnic heritage their African forebearers carried with them from their respective communities in the African continent. As Franklin Frazier argued, people of African descent are dispossessed people (Yelvington 
2001, 229). Thus, mirroring mestizaje's ideology, the Black root in the process of amalgamation in morenos' lived mestizaje does not feature as prominently as its indigenous and Spanish counterparts - its presence relegated and grounded to morenos' connection to local space and how they transmit knowledge.

Looking at mestizaje as a lived experience allows for a nuanced view of the ways morenos reconstruct what mestizaje represents. It also allows for an exploration of how morenos articulate mestizaje locally. As Wade argues, mestizaje "involves the maintenance of enduring spaces for racial-cultural differences alongside spaces of sameness" $(2005,241)$. These spaces of sameness are symbolic, as in the case of el pozole costeño, or both symbolic and physical, as in la entrega de la caja. However, these spaces are not evenly configured. The minimization of African traits highlights the imbalance in mestizaje as a lived experience.

\section{Local Mestizo}

As with religious traditions and cooking, morenos also recreate mestizaje through descent, which mirrors how Mexicans generally employ the term. In my interviews, Carmen, a dark, brown-skinned woman, hinted at this. "Mi mama era morena y mi papa mestizo; él era indígena y moreno y yo me considero mestiza (My mom was a morena and my dad a mestizo; he was indigenous and moreno, and I consider myself mestiza)." Similarly, Rafael, an older man in his forties with brown skin tone, considered himself mestizo because his mother identified as india-morena and his father blanquito (white). Mestizaje in the Mexican discourse refers exclusively to indigenous and Spanish amalgamation. More so, the national imaginary imagines mestizos as lighter skin. Nevertheless, Carmen 
and Rafael's description of their heritage provides insight into how, through the racial technology of mixing, locals racialized themselves and reconfigure and embody a type of mestizaje that includes them and mirrors the national narrative.

However, the inverse also happens as social structures constrain the subject's positionality. Galo, a fisherman in his mid-fifties, commented in an interview that although he had a moreno father and an indigenous mother, he felt like a moreno. Identifying as a moreno draws from ideas on space, phenotype, and socio-economic class. Thus, his residency in El Azufre and the fact that he was a fisherman, an occupation traditionally associated with morenos, influenced Galo’s positionality. ¿¿Con quién yo me relaciono? ¿Yo hablo una lengua? (With whom do I interact? Do I speak an indigenous tongue?)" He commented. For Galo, identifying as a moreno signified more aspects than just his genealogy. Likewise, through our conversation, he referred to how identifying as indigenous did not appear as an option for him." Ellos no me aceptan (They don't accept me)." He used "they" to refer to indigenous people. The fact that Galo looked like a moreno took precedent over his indigenous ancestry.

Mestizaje as a lived experience functions differently from mestizaje as a national ideology - which highlights indigeneity and Spanish heritage. This differentiation has significant repercussions for how people of African descent perceive themselves in Mexico. Through mestizaje's lived experience, morenos find a place of partial belonging and an ethnicity that partially locates them within social and historical narratives. The lived experience, coupled with Black bodies' racialization and its exclusion from national narratives, produces the 
discursive figure of "moreno." Thus, people of Afro-Mexicans (re)transcribes mestizaje to partially and locally reinserts people of African descent into the national narrative while distancing themselves from Blackness.

Away from Blackness

"Ya si me dicen negro, me lo encuentro re feo (I don't like when people call me Black; I find it ugly)"; "Los Negros negros están en la comunidad de Santo Domingo (The Black Black are in the community of Santo Domingo)"; "Los moyos son los negros Americanos (Moyos are Black Americans)": “me caían gordo los moyos, son muy agresivos (I didn’t like moyos, they're too aggressive)". These represent some of the comments from different collaborators I encountered during my fieldwork when I prompted morenos about what Blackness meant and who they considered Black. Various researchers have documented the extent to which morenos separate themselves from Blackness and locate it somewhere else (Vaughn 2013; Sue 2010). The reinsertion of morenos into the national imaginary necessitates the expulsion of that which does not figure in the national narrative Blackness. Thus, morenos, like many Afro-diasporic communities throughout the Americas, distance themselves from Blackness in multiple ways.

First, they draw on and emphasize their Spanish ancestry and, to a certain extent, their indigenous one. Mixture allows for a local conceptualization of mestizaje in which morenos can belong. It also serves as a form of "blanqueamiento (whitening)" (Godreau 2008 , 117). As a result, morenos commonly talk about and emphasize their "white" parent or grandparent. Likewise, this framing forces morenos to displace "Blackness" to 
somewhere else - a distant ancestor, at the neighboring house or the neighboring community. "Los negros negros, que son casi azules, estan alla (the Black Blacks, the ones who are almost blue are over there)." On the coasts of Oaxaca, regional residents consider El Azufre one of the darkest moreno communities. However, Azúfreños themselves often point to different towns and communities when describing Black people.

This emphasis on ancestry has allowed for some people of African descent to explicitly classify themselves as mestizo and consciously disassociate themselves from morenos and Blackness. For example, Jesus, a moreno from El Azufre, mentioned his ancestry and negative attitudes towards Blackness in one of our interviews.

- "I'm mestizo."

- "If someone calls me Black, I'll hit them."

- "But yeah, sometimes I've been asked if I'm from Honduras.”

- 'I've been to a lot of places, and I don't like it. I feel discriminated against if someone calls me Black."

Morenos utilize the racial technology of mixing to articulate themselves back into the national narrative and separate themselves from Blackness.

Second, the distancing from Blackness reformulates historical accounts. For example, this dynamic shows up in the erasure of people of African descent in the history books and in the origin story that relegates the presence of morenos as a result of a crashed ship. As I described in the background chapter, the schoolbooks have various silences concerning Africans' arrival and place in New Spain (Godreau 2008, 119). These silences distort local 
conceptualizations of Afro-Mexicans and perpetuate historical inaccuracies. When locals retell the story, they do not describe the recent African arrivals as slaves; sometimes, the locals do not even describe them as African but as Asian Indians. This distancing from historical accuracy ruptures their connection with slavery and its negative associations while also breaking away from an African origin.

These discursive moves have consequences. Morenos' separation from Blackness distances them from their bodies. For example, morenos tend to have varying degrees of curly hair texture. Nevertheless, women with curly hair often cut it significantly short or straightened it - see figures six and thirteen for reference. My observations and interviews with women in the community suggest that they have little local knowledge about curly hair treatment and care. In this way, the separation from Blackness and the highlighting of mestizo genealogy alienates morenos from their bodies.

As a lived experience, mestizaje construes a space in which people of African descent can embody the narratives prevalent in the national imaginary. In emphasizing their lived experience of mestizaje, people of African descent reinsert themselves into their society by articulating their common ethnic experience with the rest of the Mexican population. Nevertheless, the conceptualization of lived mestizaje limits the scope of inquiry by assuming amalgamation takes place on even grounds. This theorizing undervalues the distancing from Blackness that takes place - distancing from Africa, history of slavery, exclusion from the national imagery, and to an extent morenos' bodies. 
Since the late 1980s, morenos' distancing from Blacknes has transform. A change in subjectivity has started to materialize in Costa Chica's coasts as an effective tool and language against discrimination and lack of opportunities. Pushed by transnational currents and local efforts to fight the exclusion most morenos experience, morenos have started articulating a sense of Blackness.

Break from Morenos, The Mexican Black

"Hoy es lunes 16 de diciembre del 2019 y aquí estamos realizando un programa más de radio. Así es soy afro-Mexicano mi nombre es Rafael Lagunas y estamos contentos y esperemos que ustedes no le cambien y que estén en la sintonía de Estéreo Lluvia la voz cultural de Tututepec con su programa raíces del África (Today is Monday December 16th of 2019 and here we are making another radio program. That is right, I am Afro-Mexican; my name is Rafael Lagunas, and we're here happy and hoping you remain on this frequency of Estereo Lluvia the cultural voice of Tututepec with your program Roots from Africa)."

Rafael placed his microphone down and pressed a key on the keyboard, which cued in some music. "No Podemos parar Chava (we can't stop Chava)," he commented as he laughed - something always must be on when live. Despite joking about the scramble to find something to broadcast, Rafael always had something to say or show. Just in case his words failed him, in today's radio broadcast, Rafael had three guests. He convinced Ana, a Rio Grande moreno craftswoman, to come on the show to speak about her experience as someone of African descent. He had recruited an older gentleman to come read poetry. He had asked me to join and talk about my thoughts on racial advocacy advocacy. When the 
break ended, he took a moment to introduce us to his audience and then proceeded to guide the conversation towards what it means to be someone of African descent. He quickly turned to Ana and simultaneously commented and asked, "La identidad viene por dentro, sin importer el color, o como la ves compañera Ana (Identity comes from within, regardless of color, or what do you think Ana?)."

"Pues buenas tardes otra vez (Well, good afternoon again)," she started replying. "No hay nada malo con ser negro. Todo depende de cómo uno lo ve (There is nothing wrong with being Black. It is all about how we perceive it). "Porque pues yo me considero negra y chula como una mula verdad (I consider myself a Black woman and I think I am hot like a mule right)." "Asi es que me gusta y me quiero (That is how I like and love myself). "Lo mismo le comparto ustedes que pues meramente se quieran así mismo primero y ahora si para que nos aceptemos (I share the same with you all. The first step is to love ourselves so that we can accept ourselves)." Rafael laughed as he commented "andale pues (alright then)," "pero para mí tu eres una afromexicana hermosa como una rosa (but for me you're an Afro Mexican as beautiful as a rose)." "Porque chula como una mula no eh (Not hot like a mule)." He closed his comment by looking at Ana and saying, "we must transcend that. We have to stop self-discriminating."

Like Ana's comment, which compared her beauty to that of a mule, morenos commonly speak disparagingly about themselves. The detrimental internalization and spread of these tropes by people of African descent contrast the rampant negative stereotypes that indigenous and mestizo communities employ against morenos. Nevertheless, claiming 
Blackness has given people like Rafael a language to recognize and counteract individual and collective negative statements. "Eres una Afromexicana hermosa como una rosa (You're an Afromexican as beautiful as a rose)" demonstrates Rafael's intend in challenging negative narratives about morena women.

Originally from Charco Redondo's community, Rafael is a middle-aged moreno with a particular interest in the rights and recognition of people of African descent. Every Monday at one pm, he hosts the radio program Raices del Africa - a radio show focused on providing visibility to people of African descent by highlighting moreno artists and speaking on topics relevant to the community. According to Rafael, the program initiated a few years ago by the mobilization of Charco Redondo resident Luz Mariche who wanted to use the radio as a platform for Afro-Mexican representation. Although the program's development dwindled during its first years because of lack of participation, Rafael currently keeps the program in operation by bringing different speakers and talking about various subjects.

There is also a more explicitly political reason for these types of activities. The Mexican constitution provides and safeguards rights to minorities that demonstrate ethnic differences from the general population. Because of this, programs like Raices del Africa and other types of events held by non-governmental organizations seek to increase racial consciousness and create ethnic traditions.

People like Rafael and Luz articulate a new racialized subjectivity and consciousness. Historically morenos have invested in the separation from Blackness and their inclusion to 
national narratives through a discourse of sameness. This new articulation of Blackness directly claims and finds pride in the phenotype of people of African descent; it forms bonds of solidarity with the Black diasporas in other countries and articulates a way to integrate morenos to the Mexican nation through a discourse of difference. There is a Black consciousness taking place on the coast of Costa Chica.

Nevertheless, moreno residents and academics also contest these new ideas of Blackness. Although I could perceive this contemporary discourse taking hold during my time doing fieldwork, various people in the community of El Azufre hold very firmly to their identities as morenos. The social scientist Laura Lewis has dived into this notion, and through her writing, she emphasizes the push-back specific communities hold towards these changing ideas. "We are Mexican: we don't want to be from Africa," she quotes one of her collaborators as stating (Lewis 2000, 914). Lewis herself reformulates the term moreno, defining it in a way that references indigenous and African descent. She also conceptualizes it as the mechanism through which morenos have shown agency and attempted to belong to the nation. Nevertheless, arguments like Lewis undervalue the discrimination faced by morenos and fail to conceive the profound impact the separation from Blackness have on Afro-descendants.

During one of my conversations with Rafael Lagunas about the discrimination he has faced in Mexico and the attitudes of morenos to it, he mentioned, "No Podemos sentir la humedad adentro del rio. Ya se nos hizo normal. No identificamos a donde se nos discrimina porque eso se vive adentro de nuestra familia, nuestra comunidad y funcionarios. Tenemos que 
hacer algo. Tenemos que levantar la voz (We cannot feel the humidity when inside the river. We view it as normal. We cannot identify when we are being discriminated against because it is something we experience within our family, our community, and our politicians. So, we must do something. We have to raise our voice)." Through separation from Blackness and minimization of their racial features, morenos project Blackness to a distant place or a distant past. This distancing leaves them unable to articulate the systemic discrimination faced by their communities. The Black pride movements provide morenos with a language to articulate these grievances and speak about their experiences. Through the Black movement originating in the 1980s, morenos rearticulate their Blackness, leaving behind myths of origin that seek to exclude them, and situate themselves historically in the Mexican nation.

\section{Conclusion}

Morenos (re)articulate a version of mestizaje. This version emphasizes the traditions, tools, and people who transform the socio-cultural landscape of their respective communities. Through a lived mestizaje, morenos disarticulate racial technologies, like stating and classifying, that "others" them and attempt to place themselves within national discourse. Nevertheless, lived mestizaje lacks an adequate look into the conditions of distance from Blackness that characterize morenos' experience. Because of this, when speaking about the people of African descent in the Costa Chica region, addressing the discursive figure of "moreno" serves to better encapsulate the lived mestizaje of its residents and the erasure of Blackness present in the communities. 
The statement "Si me dices negro me ofendo (If you call me Black, I'll take offense)," as a collaborator mentioned in one of our interviews, mirrors the distance from Blackness residents employ and reference the historical processes people of African descent endured. Throughout Mexico's history, Afro-Mexicans have had to distance themselves from Blackness to survive. In colonial times residents viewed Black as synonymous with slavery and their mixed progeny as worse than their progenitors; escaping from those denominations and constructs served as a mechanism towards freedom and, at the very least, some level of acceptance. Similarly, after the period of independence when the nation-building project started occurring, Afro-Mexicans found themselves excluded from the national imaginary, which propelled the configuration of an identity that further distances its residence from Blackness. In contemporary times, these dynamics have solidified, placing morenos in contrast to what they would describe as real Blacks, like African Americans and Afro-Cubans.

In a way, the discourse of "morenos" symbolizes a way for residents to fit into the national discourse through spaces of sameness. With its connection to Africa, emphasis on phenotype, and unique ethnic traditions, Blackness further constructed people of African descent as foreign. These characteristics explain part of the push back the Black movement in the region currently receives. However, through Black pride, morenos have also found a language to articulate their struggles, the historical conditions of exclusion the Mexican nation has subjected them to and root out anti-Black sentiment. 
Through civil organizations and transnational efforts, a Black pride movement is emerging on the coast of Oaxaca and Guerrero - a movement from which morenos can draw and rearticulate their Blackness and, in doing so, their relationship with Mexico. 


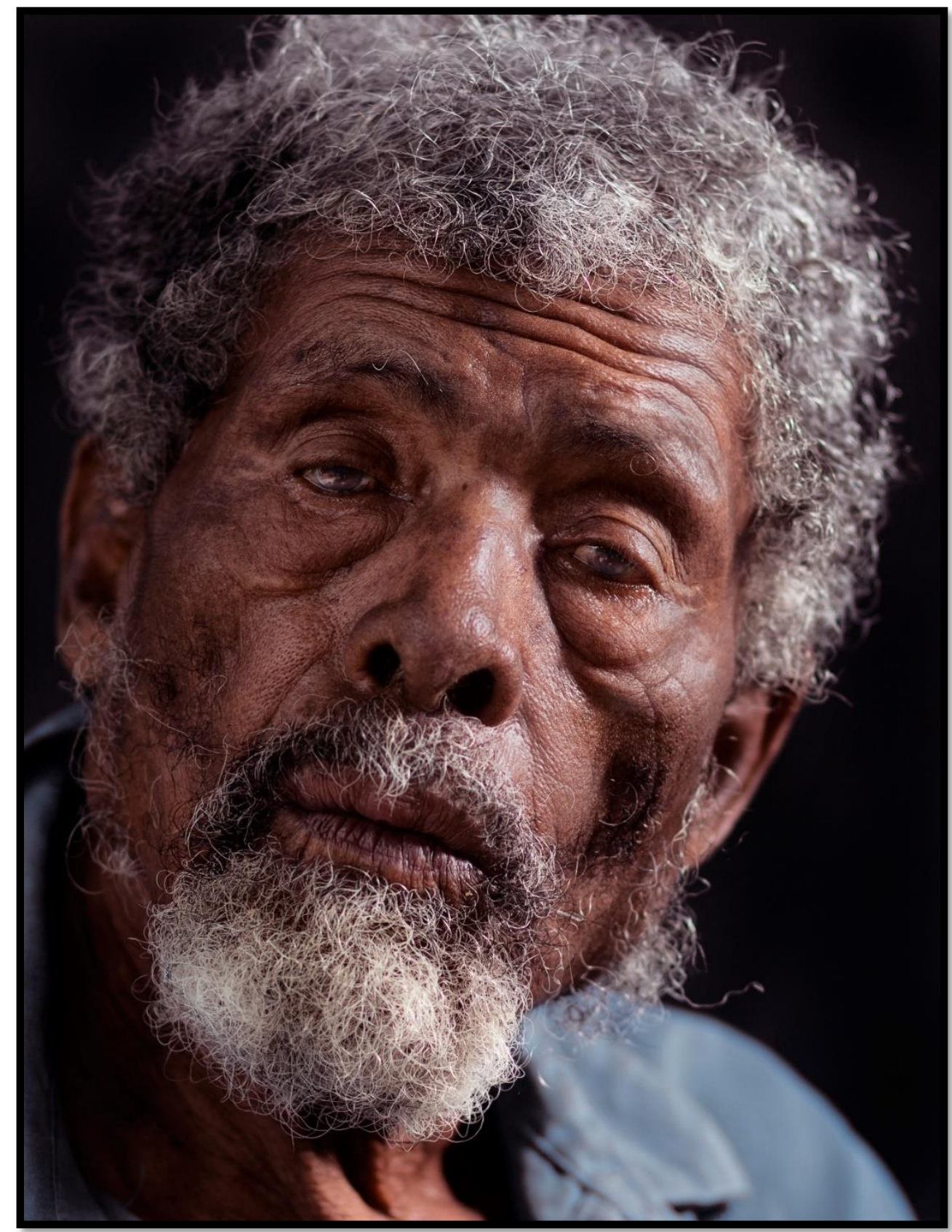

Figure 18 - Moreno man 


\section{Conclusion}

Today it poured for the second day straight. The rain dampened the ground, and patches of water have formed all around the community. The river, although contained, has begun consuming certain parts of the shore, and the few boats anchored ashore bob incessantly to the rhythm of the turbulent currents. Clouds completely cover the sky, and the forecast, according to a few locals, predicts three more days of storm. The community is finally experiencing a moment of relief from the unwavering draught gripping its harvest. The farmers are happy, and as Antonio pointed out, the rainstorm is good as water saturates the soil with moisture and allows the young corn crops to develop.

The downpour caught up to me while I visited Carolina. I found her sitting on her balcony, contemplating the rain. "Y entonces (and now)," she commented and smiled as she saw me walking through the gate of her house, meaning to say, "What do we do now?" I sat next to her, and she began talking to me about her childhood. "A mí me hubiese gustado ir a la escuela (I would've like to go to school)," she began. "Ser una doctora y saber cosas (be a doctor and know things)." She smiled before continuing.

Similarly, these days, Antonio and Carolina had pressing concerns. Antonio struggled financially, and Carolina battled with her health. With their daily struggles, they hardly had any room to prioritize questions regarding race and belonging. Thus, while racial discourse commonly permeates in the community, Azufreños talk about race inconspicuously. Nevertheless, these discourses represent a dialectical relationship between morenos and broader national narratives. Throughout this thesis, I have amplified these discourses to 
address the socio-cultural phenomena that constrain and liberate the perception and lives of morenos. These discourses take two forms.

First, discourses of racialization constitute the social structure that morenos navigate. Because of its emphasis on a whitened mestizo, the Mexican discourse of mestizaje subjects morenos to racializing discourses because of their phenotype. The African features present in the moreno communities challenged the historical narrative of the formation of the nation and the imagery around how a mixed Mexican appears. Racializing discourses abound in local, regional, national, and foreign settings. Like the Tututepec school event, regional and local narratives employ racial technologies to represent morenos as unintelligent, lazy, and promiscuous. These racial technologies decontextualize morenos' experience to imbue the "moreno" classification with characteristics the general population wants to displace. It also draws from general and foreign ideas of Blackness to categorize Afro-Mexicans as Black. Through the chapter titled "Celebrating morenos? Discourses of Differentiation," I explored these discourses while emphasizing how racialization dislodged itself from the localized experience of morenos and drew from general and foreign notions of Blackness. Locally, fellow residents subject morenos to negative stereotypes, but their majority status in the community allows them to subvert and brush off those characterizations. Regionally, morenos are classified as other, subjected to symbolic violence, and labeled as violent drug addicts, to name a few negative descriptors. Simultaneously, these local and regional discourses derive from the national erasure of people of African descent. This erasure materializes itself by excluding the Afro-Mexican population from history books, census, media production, and political representation. This 
erasure morphs and whitens Afro-Mexican contributions and origin stories. Similarly, due to the constraints place by regional and national discourses, morenos perpetuate these narratives by remaining silent and holding these views about themselves and their communities.

In addition, racialization also takes place when morenos migrate to the United States. Their experiences there, defined by the treatment they receive by other Mexicans and their experience with African Americans, transform their perspective on their Black heritage. Although more research is needed on this, throughout my interviews, I observed various patterns related to how morenos reconceptualize Blackness based on their experience abroad. For example, if morenos had a positive experience with African Americans, they return to the community with a positive discourse and attitude towards Blackness. If their experience with African Americans was negative, they further distance themselves from Blackness and hold more firmly to ideas of "moreno" and mestizaje.

Various racializing discourses frame the social structures that constrain the experience of Mexicans of African descent subjecting them to symbolic violence and placing them outside of the national narrative. Consecutively, speaking about a racializing "moreno" discourse necessitated explaining these discourses and how they emerge in local, regional, and national settings.

Second, discourses of racialization reformulate ideas of mestizaje. Through a discourse grounded on mestizaje as a lived experience, morenos reconfigure national and regional discourses to fit in. In the face of the symbolic violence employed by regional and national 
discourses, morenos reconfigure what African descent and mixed ancestry represent to occupy a space in the nation's narrative. Inclusion into the national discourse necessitates the expulsion of that which others them, Blackness. Morenos separation from Blackness has served as a historical mechanism through which to subvert socio-economic constraints. Like the mulattoes who would pass for indigenous to escape their conditions in the colonial period, morenos have employed a plethora of mechanisms to fit in. People of African descent in El Azufre use racial technologies, such as stating, classifying, and mixing, to belong and form a part of the discourse surrounding the Mexican nation. Morenos used their mixed indigenous and Spanish ancestry to label themselves in some cases as mestizos in others as moreno - imbuing the word with a meaning that references localized experiences of race, ethnicity, and nationhood. Similarly, morenos use Mexican cultural practices and traditions to fit in. I highlighted this by showcasing through pictures, songs, and narrations of national festivities the undeniable Mexican ethnic characteristic present in El Azufre.

Through the construction of a "moreno" subjectivity, people of African descent in El Azufre can claim rights to Mexican nationality and have a sense of belonging. Nevertheless, this subject positionality is always transforming and subjecting itself to contemporary tensions. The Black pride movement taking place since 1980s and the legislation of Mexico as a multi-cultural state in 2001 produced a shift in the available avenues of self-categorization of individuals. It has created a space which has fomented Blackness as a justifiable category. 
In highlighting these two types of discourses, I explored what I term the discursive figure of "moreno." "Moreno" then symbolizes a discourse based on national constraints and the attempts of communities of people of African descent in the Costa Chica region to fit in. When residents of El Azufre state "yo soy moreno (I am moreno)," they employ this word to constitute a unique discursive subject position.

\section{Implications \& Further research}

The exploration of the discourses surrounding people of African descent aids the improvement of their conditions. The commonly held stereotypes that describe Black people as violent, lazy, and promiscuous have tangible consequences for how Black people experience their daily lives. There is a global discourse that denigrates people of African heritage. The pervasiveness of these discourses mirrors and draws from one another, legitimizing themselves.

Various transnational movements and forms of mobilization for the right and recognition of people of African descent have materialized during the last few years. UNESCO and the UN declared the international decade of people of African descent and the Black Lives Matter movement, initially grounded in the experience of African Americans in the United States, has been taken up by various Afro communities throughout the world. However, there is a danger in transfiguring transnational movements locally when organizers exclude locally produced ways to navigate local tensions.

Case in point: In the case of Mexico, the Black pride movement has achieved the recognition of Afro-Mexican presence, and it has opened the door from which to speak and 
challenge the detrimental and commonly held narratives regarding morenos. Nevertheless, the movement has also been ripe with tension and exclusion due to the resistance of morenos to denominate themselves as Black. However, I want to underscore the necessity for an awareness of both the discursive structures of racialization and the historically produced (re)configuration by local actors.

Since the late 1970s, anthropologists have described the tensions between social constraints and actors through practice theory. An emphasis on these tensions allowed for a conceptualization of the ways actors are subjected to and transform their social conditions (Ortner 2006). Throughout this thesis, I have attempted to conceptualize this dynamic by focusing on racializing discourses, particularly the racial technology theorized by Biolsi (2004). Although Biolsi grounds his work on the discourse analysis proposed by Foucault, he discards how "power" functions through the people it subjugates. As Foucault states, "Power is not exercised simply as an obligation or a prohibition on those who 'do not have it'; it invests them, is transmitted by them and through them; it exerts pressure upon them, just as they themselves, in their struggle against it, resist the grip it has on them" (1977, 27). The flexibility of racializing discourses allowed morenos to simultaneously transform and perpetuate the harmful narratives prevalent in Mexico. Although my thesis describes the prevalent discourses found in different settings, further exploration of where these discourses are produced is needed. Cristina Sue investigates this issue with her analysis of subjectivity in a state-sponsored Afro-events held in Veracruz (2010). Nevertheless, studies explicitly and specifically focusing on the discourses produced in rural settings would enrich the understanding of how these discourses take hold. 
The case of the people of African descent in El Azufre exemplifies how discourses function to racialized certain groups. It also demonstrates how the group utilized their own discourse to (re)insert themselves into dominant narratives and distance themselves from racialized subjectivity. This dynamic constitutes a unique discursive subject position - that of the Mexican moreno. That said, how does the subjectivity of Costa Chica morenos differ from that of people of African descent in order parts of Mexico?

The emphasis on locally produced and embodied discourses opens a couple of divergent lines of inquiry. Because of their rurality, moreno communities in Costa Chica have limited intervention by broad governmental programs and initiatives. Their difference from urban contexts leads me to wonder how racializing discourses differ based on proximity to urban settings and government programs. How do rural and urban efforts to (re)articulate Blackness and mestizaje differ? Through what mechanism do people of African descent become racialized in urban settings? What are the differences between Costa Chica morenos and people of African descent in other regions of Mexico who are not readily constructed as Black by the regional narratives or as morenos by themselves?

Likewise, the movement seeking Black pride and recognition in the region of Costa Chica also necessitates deeper exploration into how the symbolic violence perpetuated against morenos is changing and how morenos use this language to subvert the social structures that contain them. How are morenos articulating the new racial discourse on Blackness? What are the socio-economic incentives, or lack thereof, that facilitate the articulation of Blackness? 
Morenos represents a formulation of the African Diaspora. Although researchers tend to present Afro-diasporic communities in the Atlantic, the case of morenos provides inclusion of the Mestizo-America context into these narratives. It also highlights the discursive nature of race and how subject positions are in a constant state of transformation. To explore these and better address the experience of people of African descent throughout the Americas, I find it important to move away from generalized, fixed, and often unquestioned Americanized (U.S.) ideas of Blackness. This change would allow research to accurately explore, represent, and nuance the experience of people of African descent. 


\section{Work Cited}

Aguirre-Beltrán, Gonzalo. 1972. La población negra de México; estudio etnohistórico. [2. ed., corr. Y aum.]. Colección Tierra firme (Fondo de Cultura Económica (Mexico)). México: Fonde de Cultura Económica.

Aguirre-Beltrán, Gonzalo. 1958. Cuijla, esbozo etnográfico de un pueblo negro. [1. ed.]. Fondo de cultura economica. Sección de obras de antropología. México: Fondo de Cultura Económica.

Aguirre-Beltrán, Gonzalo. 1944. "The Slave Trade in Mexico." The Hispanic American Historical Review 24 (3): 412-31. https://doi.org/10.1215/00182168-24.3.412.

Butler, Judith. 1993. Bodies That Matter: On the Discursive Limits of "Sex." New York: Routledge.

Carrier, Joseph. 1995. De Los Otros: Intimacy and Homosexuality among Mexican Men. Between Men--between Women. New York: Columbia University Press.

Davenport, Lauren. 2020. "The Fluidity of Racial Classifications." Annual Review of Political Science 23 (1): 221-40. https://doi.org/10.1146/annurev-polisci-060418$\underline{042801 .}$.

Davidson, David M. 1966. "Negro Slave Control and Resistance in Colonial Mexico, 1519-1650." The Hispanic American Historical Review 46 (3): 235-53. https://doi.org/10.1215/00182168-46.3.235.

Decena, Carlos Ulises. 2011. Tacit Subjects: Belonging and Same-Sex Desire among Dominican Immigrant Men. Durham, NC: Duke University Press.

Eduardo Bonilla-Silva. 1997. "Rethinking Racism: Toward a Structural Interpretation." American Sociological Review 62 (3): 465-80. https://doi.org/10.2307/2657316.

Foucault, Michel. 1972. The Archaeology of Knowledge. 1st American ed. World of Man (London, England). New York, NY: Pantheon Books.

- 1977. Discipline and Punish: The Birth of the Prison. 1st American ed. New York: Pantheon Books.

Gabriela Iturralde. 2017. "Obstáculos al reconocimiento constitucional de los pueblos y comunidades afromexicanas: ¿objeciones del racismo?” Antropologías del Sur, no. 8: $127-47$.

Gardner, Andrew, and David M. Hoffman. 2006. Dispatches from the Field: Neophyte Ethnographers in a Changing World. Long Grove, Ill.: Waveland Press.

Gilroy, Paul. 1993. The Black Atlantic: Modernity and Double Consciousness. Cambridge, Massachusetts: Harvard University Press. 
Godreau, Isar P., Mariolga Reyes Cruz, Mariluz Franco Ortiz, and Sherry Cuadrado. 2008. "The Lessons of Slavery: Discourses of Slavery, Mestizaje, and Blanqueamiento in an Elementary School in Puerto Rico." American Ethnologist 35 (1): 115-35. https://doi.org/10.1111/j.1548-1425.2008.00009.x.

Gonzalez Estrella, Jorge. 2012. "The (Re)Construction of Blackness in Costa Chica, Oaxaca: NGOs and the Making of an Afro-Mexican Ethnic Group." ProQuest Dissertations Publishing. https://search.proquest.com/docview/1237240425?pqorigsite $=$ primo.

Green, Debra D. 2007. "Africanity among African Mexicans: An Afrocentric Study of Identity Formation in a Mexican Community." ProQuest Dissertations Publishing. https://search.proquest.com/docview/304827981?pq-origsite=primo.

—. 2010. "African Mexicans in Spanish Slave Societies in America: A Critical Location of Sources." Journal of Black Studies 40 (4): 683-99. https://doi.org/10.1177/0021934708318596.

Hall, S. 1995. "Negotiating Caribbean Identities.” New Left Review, no. 209: 3-14.

Hall, Stuart, David Held, and Anthony G. McGrew. 1992. Modernity and Its Futures. Understanding Modern Societies; Bk. 4. Cambridge: Polity Press in association with the Open University.

Herman L Bennett. 2003. Africans in Colonial Mexico: Absolutism, Christianity, and Afro-Creole Consciousness, 1570-1640. Blacks in the Diaspora. Bloomington: Indiana University Press.

Hoffman, Odile. 2006. "Negros y afromestizos en México: viejas y nuevas lecturas de un mundo olvidado." Revista mexicana de sociología 68 (1): 103-35.

Howard Winant. 2004. The New Politics of Race: Globalism, Difference, Justice. NEDNew edition. Minneapolis: University of Minnesota Press. https://doi.org/10.5749/j.ctttsb02.

Ilan Stavans. 2011. José Vasconcelos: The Prophet of Race. Piscataway: Rutgers University Press.

Jagose, Annamarie. 1996. Queer Theory: An Introduction. New York: University Press.

Laura A Lewis. 2000. "Blacks, Black Indians, Afromexicans: The Dynamics of Race, Nation, and Identity in a Mexican 'Moreno' Community (Guerrero)." American Ethnologist 27 (4): 898-926. https://doi.org/10.1525/ae.2000.27.4.898.

- 2001. "Of Ships and Saints: History, Memory, and Place in the Making of Moreno Mexican Identity." Cultural Anthropology 16 (1): 62-82. https://doi.org/10.1525/can.2001.16.1.62. 
Lewis, Laura A. 2012. Chocolate and Corn Flour: History, Race, and Place in the Making of "Black" Mexico. Durham: Duke University Press.

McDonald, James. 2016. "Expanding Queer Reflexivity: The Closet as a Guiding Metaphor for Reflexive Practice." Management Learning 47 (4): 391-406. https://doi.org/10.1177/1350507615610029.

Miller, Marilyn Grace. 2004. Rise and Fall of the Cosmic Race the Cult of Mestizaje in Latin America. 1st. ed. Austin: University of Texas Press.

$\underline{\text { http://search.ebscohost.com/login.aspx? } \text { direct }=\text { true } \& \text { scope }=\text { site } \& \mathrm{db}=\mathrm{nlebk} \& \mathrm{db}=\mathrm{n}}$ labk\&AN=131003.

Molina, Natalia, Daniel HoSang, and Ramón A. Gutiérrez. 2019. Relational Formations of Race: Theory, Method, and Practice. Oakland, California: University of California Press.

Murji, Karim, and John Solomos. 2005. Racialization: Studies in Theory and Practice. Oxford ; New York: Oxford University Press.

Nugent, David, and Joan Vincent. 2004. A Companion to the Anthropology of Politics. Blackwell Companions to Anthropology 2. Malden, MA: Blackwell Pub.

Ortner, Sherry B. 2006. Anthropology and Social Theory: Culture, Power, and the Acting Subject. Durham: Duke University Press.

Palmer, Colin. 1976. Slaves of the White God. 1st Edition. Harvard University Press. https://www.hup.harvard.edu/catalog.php?isbn=9780674181823.

Paz, Octavio. 1972. El laberinto de la soledad. 2a ed., rev. Y aum. Colección popular (Fondo de Cultura Económica (Mexico)) 107. México: Fondo de Cultura Económica.

Quecha Reyna, Citlali. 2015a. "La movilización etnopolítica afrodescendiente en México y el patrimonio cultural inmaterial.” Anales de antropología 49 (2): 149-73. https://doi.org/10.1016/S0185-1225(15)30006-0.

—. 2015b. "La movilización etnopolítica afrodescendiente en México y el patrimonio cultural inmaterial.” Anales de antropología 49 (2): 149-73. https://doi.org/10.1016/S0185-1225(15)30006-0.

Ramos, Marisela Jimenez. 2009. "Black Mexico: Nineteenth-Century Discourses of Race and Nation." ProQuest Dissertations Publishing. https://search.proquest.com/docview/304831474?pq-origsite=primo.

Ramsay, Paulette A. 2004. "History, Violence and Self-Glorification in Afro-Mexican Corridos from Costa Chica de Guerrero." Bulletin of Latin American Research 23 (4): 446-64. https://doi.org/10.1111/j.0261-3050.2004.00118.x. 
Restall, Matthew. 2000. "Black Conquistadors: Armed Africans in Early Spanish America." The Americas (Washington. 1944) 57 (2): 171-205. https://doi.org/10.1353/tam.2000.0015.

Sue, Christina A. 2010. "Racial Ideologies, Racial-Group Boundaries, and Racial Identity in Veracruz, Mexico." Latin American and Caribbean Ethnic Studies 5 (3): 27399. https://doi.org/10.1080/17442222.2010.513829.

Sylvia Wynter. 2003. "Unsettling the Coloniality of Being/Power/Truth/Freedom: Towards the Human, After Man, Its Overrepresentation-An Argument." CR (East Lansing, Mich.) 3 (3): 257-337. https://doi.org/10.1353/ncr.2004.0015.

Ulysse, Gina. 2002. “Conquering Duppies in Kingston: Miss Tiny and Me, Fieldwork Conflicts, and Being Loved and Rescued." Anthropology and Humanism 27 (1): 10-26. https://doi.org/10.1525/anhu.2002.27.1.10.

Valdés, Dennis N. 2018. "The Decline of Slavery in Mexico." The Americas (Washington. 1944) 75 (1): 167-94.

Vaughn, Bobby. 2013. "Mexico Negro: From the Shadows of Nationalist Mestizaje to New Possibilities in Afro-Mexican Identity." The Journal of Pan African Studies 6 (1): 227-.

Vaughn, Vinson III Ben y Bobby. 2005. Afroméxico. El pulso de la población negra en México: una historia recordada, olvidada y vuelta a recordar. México, D.F: Fondo de Cultura Económica.

Virginia R Domínguez. 2000. "For a Politics of Love and Rescue." Cultural Anthropology 15 (3): 361-93. https://doi.org/10.1525/can.2000.15.3.361.

Wade, Peter. 2005. "Rethinking Mestizaje: Ideology and Lived Experience.” Journal of Latin American Studies 37 (2): 239-57. https://doi.org/10.1017/S0022216X05008990.

Warner, Michael and Social Text Collective. 1993. Fear of a Queer Planet: Queer Politics and Social Theory. First edition. Cultural Politics (Minneapolis, Minn.); v. 6. Minneapolis: University of Minnesota Press.

Weltman-Cisneros, Talia, and Candelaria Donaji Mendez Tello. 2013. "NegrosAfromexicanos: Recognition and the Politics of Identity in Contemporary Mexico." The Journal of Pan African Studies 6 (1): 140-57.

Yelvington, Kevin A. 2001. "THE ANTHROPOLOGY OF AFRO-LATIN AMERICA AND THE CARIBBEAN: Diasporic Dimensions.” Annual Review of Anthropology 30 (1): 227-60. https://doi.org/10.1146/annurev.anthro.30.1.227. 